\title{
Geomorphic and Vegetation Processes of the Willamette River Floodplain, Oregon-Current Understanding and Unanswered Questions
}

By J. Rose Wallick, Krista L. Jones, Jim E. O'Connor, and Mackenzie K. Keith, U.S. Geological Survey; David Hulse, University of Oregon; and Stanley V. Gregory, Oregon State University

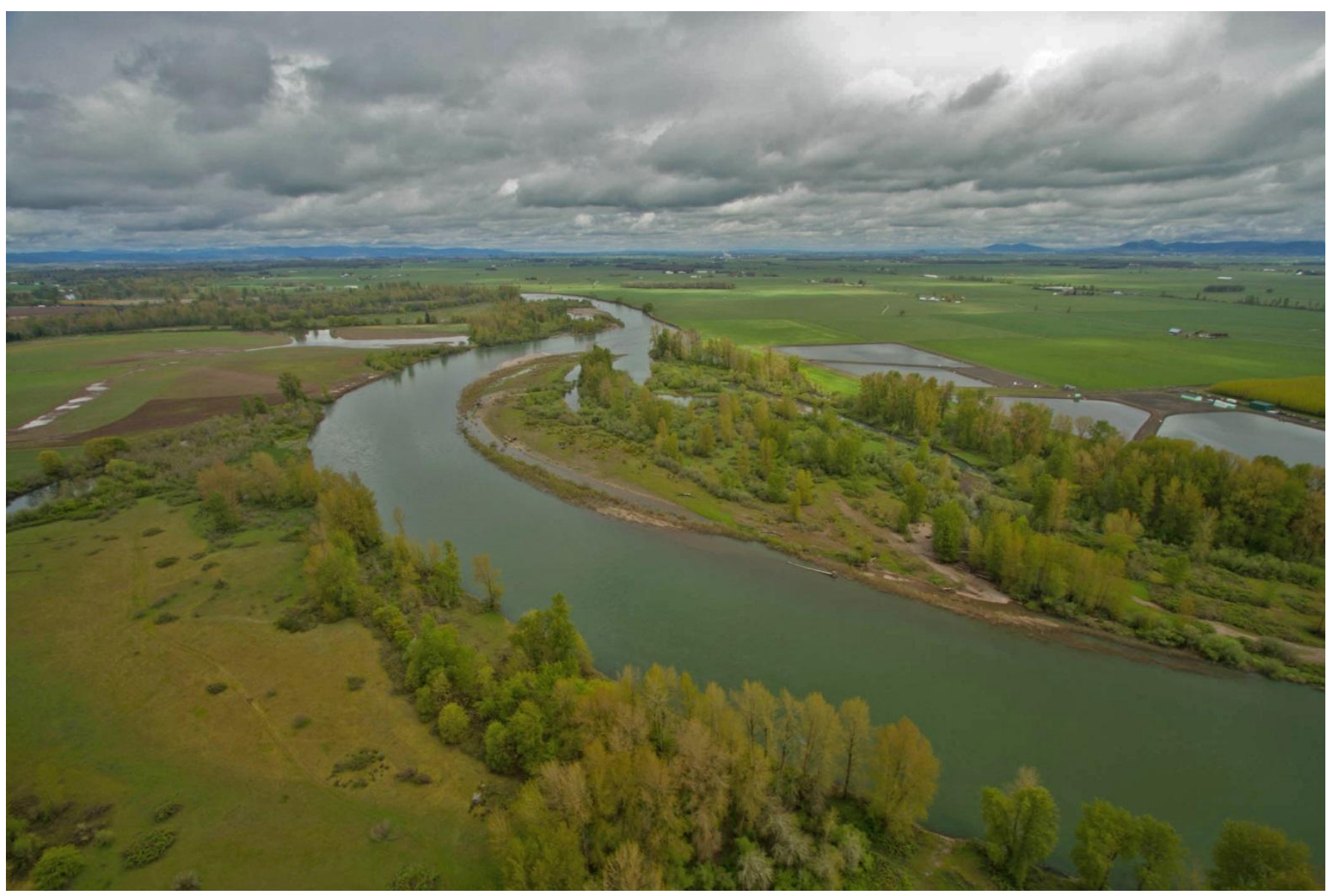

Prepared in cooperation with the Benton County Soil and Water Conservation District Open-File Report 2013-1246

U.S. Department of the Interior U.S. Geological Survey 
Cover: Upper Willamette River near Harrisburg, April 2011. Photograph courtesy of Freshwaters Illustrated. 


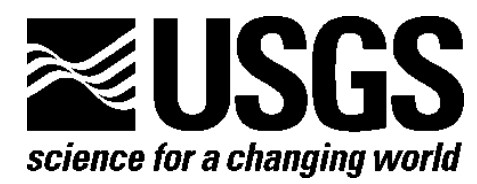

\section{Geomorphic and Vegetation Processes of the Willamette River Floodplain, Oregon-Current Understanding and Unanswered Questions}

By J. Rose Wallick, Krista L. Jones, Jim E. O'Connor, and Mackenzie K. Keith, U.S. Geological Survey; David Hulse, University of Oregon; and Stanley V. Gregory, Oregon State University

Prepared in cooperation with the Benton County Soil and Water Conservation District

Open-File Report 2013-1246

U.S. Department of the Interior

U.S. Geological Survey 


\section{U.S. Department of the Interior \\ SALLY JEWELL, Secretary}

\section{U.S. Geological Survey \\ Suzette Kimball, Acting Director}

U.S. Geological Survey, Reston, Virginia 2013

For more information on the USGS—-the Federal source for science about the Earth, its natural and living resources, natural hazards, and the environment: - visit http://www.usgs.gov or call 1-888-ASK-USGS

For an overview of USGS information products, including maps, imagery, and publications, visit $h$ ttp://www.usgs.gov/pubprod

To order this and other USGS information products, visit $h$ ttp://store.usgs.gov

Any use of trade, product, or firm names is for descriptive purposes only and does not imply endorsement by the U.S. Government.

Although this report is in the public domain, permission must be secured from the individual copyright owners to reproduce any copyrighted material contained within this report.

Suggested citation:

Wallick, J.R., Jones, K.L. O'Connor, J.E., Keith, M.K., Hulse, David, and Gregory, S.V., 2013, Geomorphic and vegetation processes of the Willamette River floodplain, Oregon-Current understanding and unanswered questions: U.S. Geological Survey Open-File Report 2013-1246., 70 p., http://dx.doi.org/10.3133/ofr20131246.

ISSN 2331-1258 (online) 


\section{Contents}

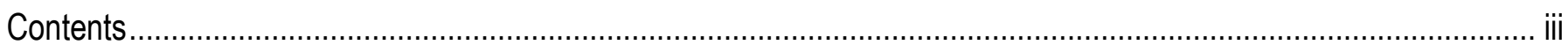

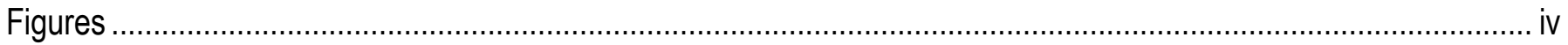

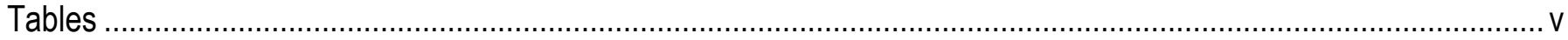

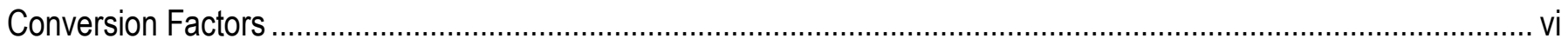

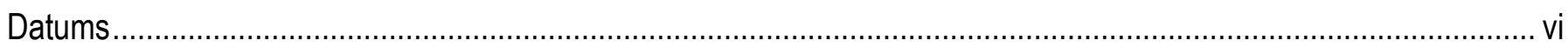

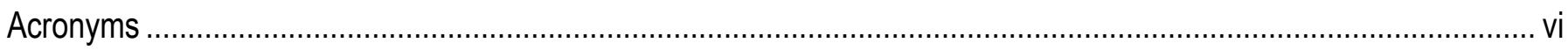

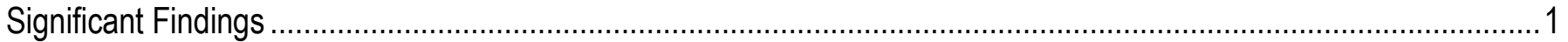

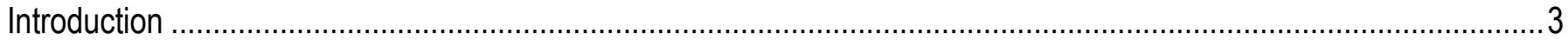

The Willamette River Basin and Study Area …........................................................................................... 5

Primer on the Willamette River Geomorphic Floodplain ............................................................................... 8

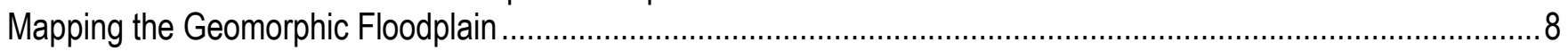

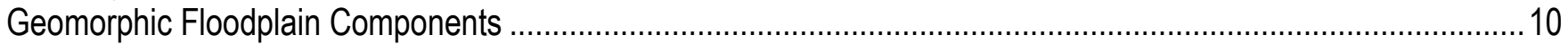

Controls and Processes Shaping the Geomorphic Floodplain and Riparian Vegetation .......................................15

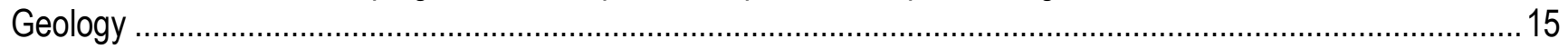

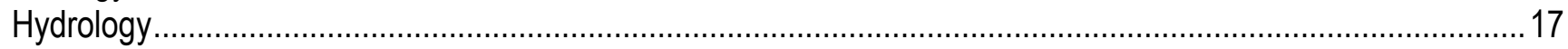

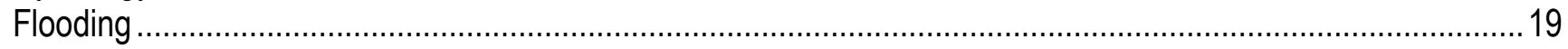

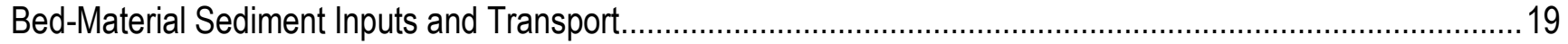

Large Wood Delivery and Transport .................................................................................................... 19

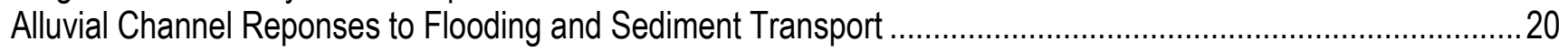

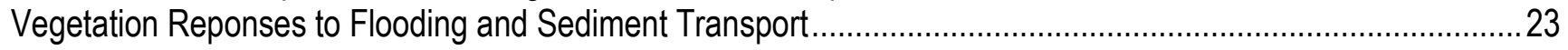

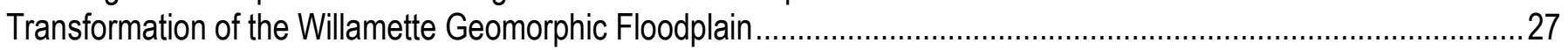

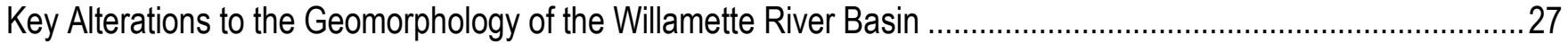

Reductions in Floods and Bed-Material Sediment by Dams .................................................................2

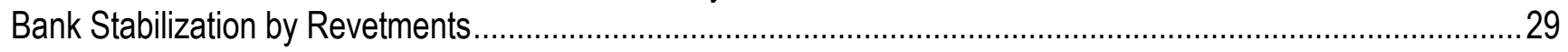

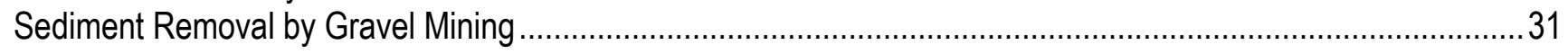

Reduced Large Wood Inputs and Transport ......................................................................................

Consequences of Changes in Floods, Sediment Fluxes, and Bank Stability ...................................................32

Coarsening of the Channel Bed Downstream of Dams ...........................................................................

Widespread Loss of Side Channels, Islands, and Unvegetated Gravel Bars...................................................33

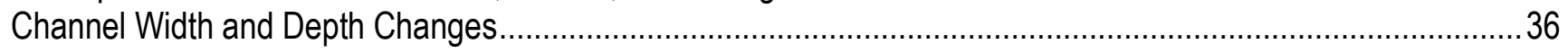

Decreased Channel Mobility ................................................................................................................ 38

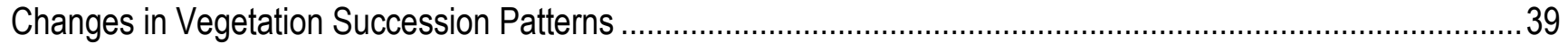

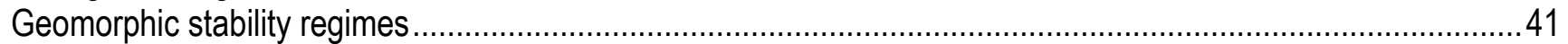

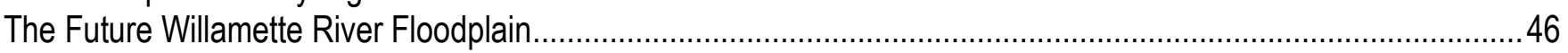

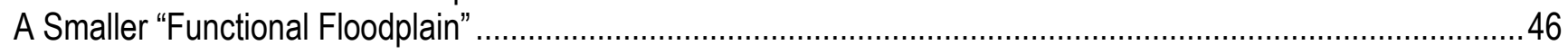

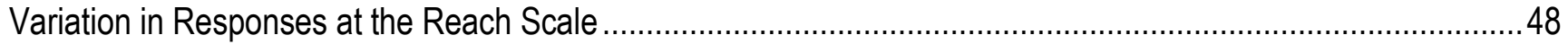

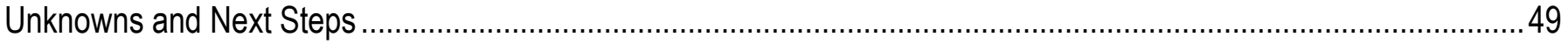

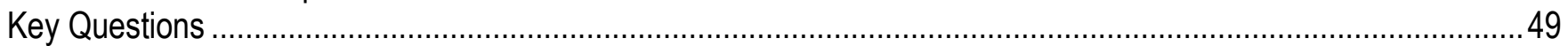

Question 1: What is the distribution and diversity of landforms and habitats along the Willamette River and its

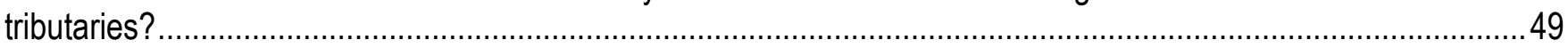

Question 2: What is the footprint of today's functional floodplain? .................................................................50

Question 3: How are landforms and habitats in the Willamette River Basin created and reshaped by presentday flow and sediment conditions?

Question 4: How is the succession of native floodplain vegetation shaped by present-day flow and sediment conditions? 


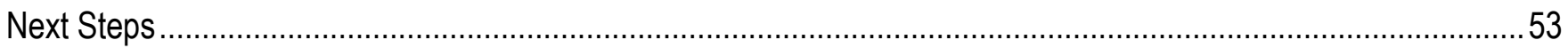

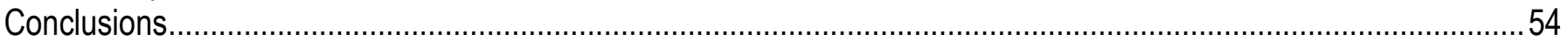

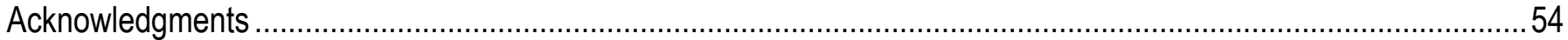

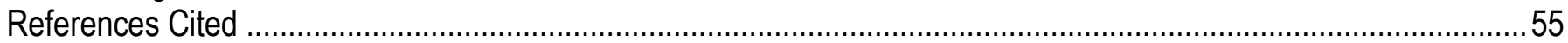

Appendix A.Geomorphic Descriptions of Valley Segments of the Willamette River Basin Study Area........................62

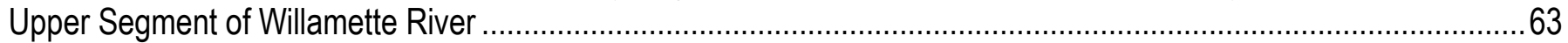

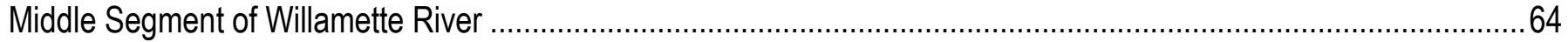

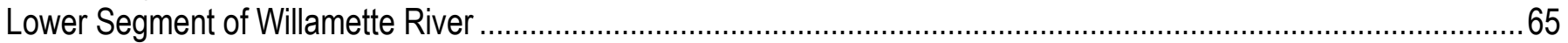

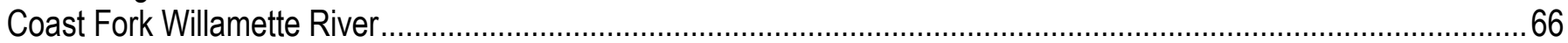

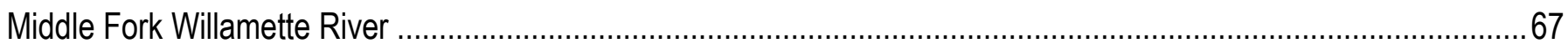

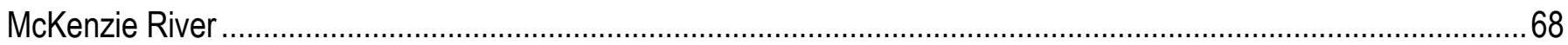

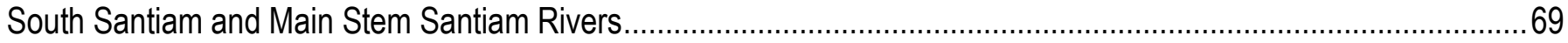

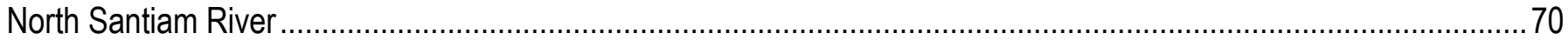

\section{Figures}

Figure 1. Map showing geology and topography of Willamette River Basin, Oregon.

Figure 2. Map showing geomorphic floodplain study area for Willamette River and major tributaries draining the Cascade Range, Oregon.

Figure 3. Longitudinal profiles showing Willamette River and major tributaries downstream of U.S. Army Corps of Engineers dams, Oregon.

Figure 4. Generalized cross section (not to scale) showing channel features and geological units of the Willamette River Valley, Oregon.

Figure 5. Examples of channel and floodplain landforms along the Willamette River near floodplain kilometer 195, Harrisburg, Oregon.

Figure 6. Examples of channel and floodplain landforms on the upper segment of the Willamette River near floodplain kilometer 214, Green Island, Oregon.

Figure 7. Examples of floodplain topography, sloughs, and swales on the Willamette River, Oregon.

Figure 8. Generalized cross section showing variation in native vegetation with floodplain topography of the Willamette River Basin, Oregon.

Figure 9. Comparison of active channel features and vegetation in the Willamette River Basin, Oregon.

Figure 10. Conceptual model of dominant processes shaping landforms and habitats of Willamette River Basin,

Oregon, floodplains.

Figure 11. Examples of meander migration and avulsion on upper Willamette River near floodplain kilometer 183, Peoria, Oregon, 1994-2011.

Figure 12. Examples of meander migration and avulsions on North Santiam River near floodplain kilometer 9 , Marion, Oregon, 1994-2011.

Figure 13. Conceptual model of native vegetation succession for Willamette River, Oregon, floodplains............23

Figure 14. Graph showing example of natural and regulated mean monthly flows for the McKenzie River at Vida, Oregon, and implications for stand initiation.

Figure 15. Diagrams showing relationships between channel change and vegetation succession.

Figure 16. Historical changes to riparian forests along the upper segment of Willamette River near floodplain kilometer 205, Junction City, Oregon, 1939-2011. 
Figure 17. Maps showing historical channel change in the upper valley segment of Willamette River near floodplain kilometers 200-210, Junction City, Oregon, 1850-1995.

Figure 18. Graph showing peak annual discharge for U.S. Geological Survey streamflow-gaging station Willamette River at Albany, Oregon, (14174000), 1861-2012. 28

Figure 19. Bed-material flux estimates from O'Connor and others (in press). 30

Figure 20. Aerial photographs showing changes in the upper valley segment of the Willamette River near floodplain kilometers 205-210, Junction City, Oregon, 1939-2011.....

Figure 21. Aerial photographs showing changes in the Willamette River and Middle Fork Willamette River, Oregon, 1939-2011.

Figure 22. Specific gage analyses for select rivers in the Willamette Basin, Oregon.

Figure 23. Relations among major floodplain elements reflecting dominant historical and current process regimes on the upper segment of the Willamette River, Oregon, near floodplain kilometer 205.

Figure A-1. Upper segment of Willamette River, Oregon, floodplain and active channel ....................................63

Figure A-2. Middle segment of Willamette River, Oregon, floodplain and active channel.....................................64

Figure A-3. Lower segment of Willamette River, Oregon, floodplain and active channel. ....................................65

Figure A-4. Coast Fork Willamette River, Oregon, floodplain and active channel. ............................................6

Figure A-5. Middle Fork Willamette River, Oregon, floodplain and active channel ...........................................67

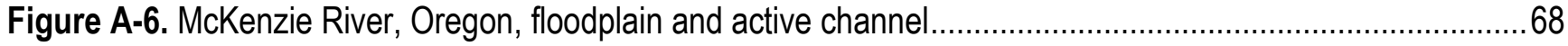

Figure A-7. South Santiam River and Santiam River, Oregon, floodplain and active channel.............................69

Figure A-8. North Santiam River, Oregon, floodplain and active channel ...................................................... 70

\section{Tables}

Table 1. Summary of aerial photography and topography data reviewed in this study.

Table 2. Key U.S. Geological Survey streamflow gaging stations for Willamette River and major tributaries, Oregon.

Table 3. Summary descriptions of channel characteristics for Willamette River, Oregon, and major salmonbearing tributaries downstream of the U.S. Army Corps of Engineers dams

Table 4. Summary descriptions of lateral and vertical stability for Willamette River, Oregon, and major salmonbearing tributaries downstream of the U.S. Army Corps of Engineers dams 


\section{Conversion Factors, Datums, and Acronyms}

\section{Conversion Factors}

\begin{tabular}{lll}
\hline Multiply & By & To obtain \\
\hline & Length & \\
\hline meter $(\mathrm{m})$ & 3.281 & foot $(\mathrm{ft})$ \\
kilometer $(\mathrm{km})$ & 0.6214 & mile $(\mathrm{mi})$ \\
\hline & Area & \\
\hline square meter $\left(\mathrm{m}^{2}\right)$ & 10.76 & square foot $\left(\mathrm{ft}^{2}\right)$ \\
hectare $($ ha) & 2.471 & acre \\
square kilometer $\left(\mathrm{km}^{2}\right)$ & 0.3861 & square mile $\left(\mathrm{mi}^{2}\right)$ \\
\hline & Flow rate & \\
\hline cubic meter per second $\left(\mathrm{m}^{3} / \mathrm{s}\right)$ & 35.31 & cubic foot per second $\left(\mathrm{ft}^{3} / \mathrm{s}\right)$ \\
cubic meter per year $\left(\mathrm{m}^{3} / \mathrm{yr}\right)$ & 1.308 & cubic yard per year $\left(\mathrm{yd}^{3} / \mathrm{yr}\right)$ \\
millimeter per year $(\mathrm{mm} / \mathrm{yr})$ & 0.03937 & inch per year $(\mathrm{in} / \mathrm{yr})$ \\
\hline
\end{tabular}

NOTE TO USGS USERS: Use of hectare (ha) as an alternative name for square hectometer $\left(\mathrm{hm}^{2}\right)$ is restric ted to the measurement of small land or water areas.

\section{Datums}

Vertical coordinate information is referenced to the North American Vertical Datum of 1988 (NAVD 88). Elevation, as used in this report, refers to distance above the vertical datum.

Horizontal coordinate information is referenced to the North A merican Datum of 1983 (NAD 83).

\section{Acronyms}

$\begin{array}{ll}\text { FPKM } & \text { floodplain kilometer } \\ \text { NAIP } & \text { National Agriculture Imagery Program } \\ \text { NOAA } & \text { National Oceanic and Atmospheric Administration } \\ \text { ODFW } & \text { Oregon Department of Fish and Wildlife } \\ \text { OSU } & \text { Oregon State University } \\ \text { UO } & \text { University of Oregon } \\ \text { USACE } & \text { U.S. Army Corps of Engineers } \\ \text { USFWS } & \text { U.S. Fish and Wildlife Service } \\ \text { USGS } & \text { U.S. Geological Survey }\end{array}$




\section{Geomorphic and Vegetation Processes of the Willamette River Floodplain, Oregon-Current Understanding and Unanswered Questions}

By J. Rose Wallick, Krista L. Jones, Jim E. O'Connor, and Mackenzie K. Keith, U.S. Geological Survey; David Hulse, University of Oregon; and Stanley V. Gregory, Oregon State University

\section{Significant Findings}

This report summarizes the current understanding of floodplain processes and landforms for the Willamette River and its major tributaries. The area of focus encompasses the main stem Willamette River above Newberg and the portions of the Coast Fork Willamette, Middle Fork Willamette, McKenzie, and North, South and main stem Santiam Rivers downstream of U.S. Army Corps of Engineers dams. These reaches constitute a large portion of the alluvial, salmon-bearing rivers in the Willamette Basin.

The geomorphic, or historical, floodplain of these rivers has two zones - the active channel where coarse sediment is mobilized and transported during annual flooding and overbank areas where fine sediment is deposited during higher magnitude floods. Historically, characteristics of the rivers and geomorphic floodplain (including longitudinal patterns in channel complexity and the abundance of side channels, islands and gravel bars) were controlled by the interactions between floods and the transport of coarse sediment and large wood. Local channel responses to these interactions were then shaped by geologic features like bedrock outcrops and variations in channel slope.

Over the last 150 years, floods and the transport of coarse sediment and large wood have been substantially reduced in the basin. With dam regulation, nearly all peak flows are now confined to the main channels. Large floods (greater than 10-year recurrence interval prior to basinwide flow regulation) have been largely eliminated. Also, the magnitude and frequency of small floods (events that formerly recurred every 2-10 years) have decreased substantially. The large dams trap an estimated 50-60 percent of bed-material sediment - the building block of active channel habitats - that historically entered the Willamette River. They also trap more than 80 percent of the estimated bed material in the lower South Santiam River and Middle and Coast Forks of the Willamette River. Downstream, revetments further decrease bed-material supply by an unknown amount because they limit bank erosion and entrainment of stored sediment.

The rivers, geomorphic floodplain, and vegetation within the study area have changed noticeably in response to the alterations in floods and coarse sediment and wood transport. Widespread decreases have occurred in the rates of meander migration and avulsions and the number and diversity of landforms such as gravel bars, islands, and side channels. Dynamic and, in some cases, multi-thread river segments have become stable, single-thread channels. Preliminary observations suggest that forest area has increased within the active channel, further reducing the area of unvegetated gravel bars.

Alterations to floods and sediment transport and ongoing channel, floodplain, and vegetation responses result in a modern Willamette River 
Basin. Here, the floodplain influenced by the modern flow and sediment regimes, or the functional floodplain, is narrower and inset with the broader and older geomorphic floodplain. The functional floodplain is flanked by higher elevation relict floodplain features that are no longer inundated by modern floods. The corridor of present-day active channel surfaces is narrower, enabling riparian vegetation to establish on formerly active gravel bar surfaces.

The modern Willamette River Basin with its fundamental changes in the flood, sediment transport, and large wood regimes has implications for future habitat conditions. System-wide future trends probably include narrower floodplains and a lower diversity of landforms and habitats along the Willamette River and its major tributaries compared to historical patterns and today.

Furthermore, specific conditions and future trends will probably vary between geologically stable, anthropogenically stable, and dynamic reaches. The middle and lower segments of the Willamette River are geologically stable, whereas the South Santiam and Middle Fork Willamette Rivers were historically dynamic, but are now largely stable in response to flow regulation and revetment construction. The upper Willamette and North Santiam Rivers retain some dynamic characteristics, and provide the greatest diversity of aquatic and riparian habitats under the current flow and sediment regime. The McKenzie River has some areas that are more dynamic, whereas other sections are stable due to geology or revetments.

Historical reductions in channel dynamism also have implications for ongoing and future recruitment and succession of floodplain forests. For instance, the succession of native plants like black cottonwood is currently limited by (1) fewer low-elevation gravel bars for stand initiation; (2) altered streamflow during seed release, germination, and stand initiation; (3) competition from introduced plant species; and (4) frequent erosion of young vegetation in some locations because scouring flows are concentrated within a narrow channel corridor.

Despite past alterations, the Willamette River Basin has many of the physical and ecological building blocks necessary for highly functioning rivers. Management strategies, including environmental flow programs, river and floodplain restoration, revetment modifications, and reclamation of gravel mines, are underway to mitigate some historical changes. However, there are some substantial gaps in the scientific understanding of the modern Willamette basin that is needed to efficiently integrate these blocks and to establish realistic objectives for future conditions. Unanswered questions include:

1. What is the distribution and diversity of landforms and habitats along the Willamette River and its tributaries?

2. What is the extent of today's functional floodplain - the part of the river corridor actively formed and modified by fluvial processes?

3. How are landforms and habitats in the Willamette River Basin created and sustained by present-day flow and sediment conditions?

4. How is the succession of native floodplain vegetation shaped by present-day flow and sediment conditions?

Answering these questions will produce baseline data on the current distributions of landforms and habitats (question 1), the extent of the functional floodplain (question 2), and the effects of modern flow and sediment regimes on future floodplain landforms, habitats, and vegetation succession (questions 3 and 4). Addressing questions 1 and 2 is a logical next step because they underlie questions 3 and 4 . Addressing these four questions would better characterize the modern Willamette Basin and help in implementing and setting realistic targets for ongoing management strategies, demonstrating their effectiveness at the site and basin scales, and anticipating future trends and conditions. 


\section{Introduction}

Gravel-bed rivers, such as the Willamette River and its tributaries draining the Cascade Range, have been referred to as "authors of their own geometries" (Leopold and Langbein, 1962) because they can adjust their shapes over time in response to streamflow and inputs of sediment and large wood. Since about 1850 , humans increasingly have contributed to the evolution of channel geometries in the Willamette River Basin. Flood control, bank stabilization, large-wood removal, and the conversion of riparian forests to agricultural fields have substantially changed the quantity of water, sediment, and large wood moving through the basin and, in some cases, the ability of channels to adjust to these changes.

Changing societal values and increased understanding of river processes has motivated several restoration and conservation approaches for mitigating these historical changes and their ecologic consequences. In particular, the following interrelated activities are either being considered or have already been implemented in the Willamette Basin:

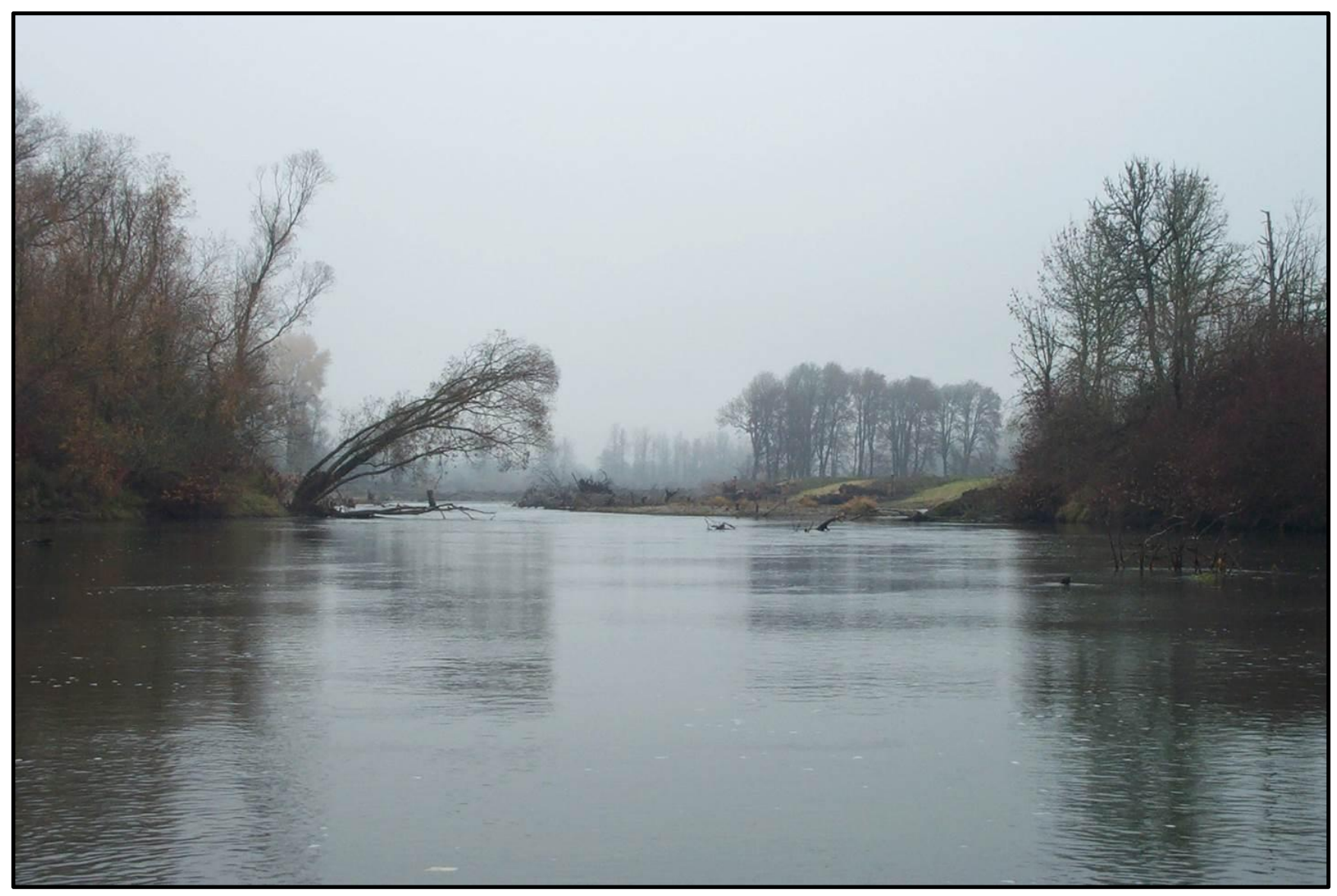

Upper segment of the Willamette River near Junction City. Photograph by Gordon Grant, December 2003. 


\section{River and floodplain restoration-} Multiple agencies and organizations are investing in aquatic and riparian restoration to create or enhance habitats and to help recover salmon, other native fish, and other species listed under the Endangered Species Act. For example, the Oregon Watershed Enhancement Board (OWEB) invested approximately $\$ 2.5$ million between 2008 and 2013 on restoration along the main stem Willamette River (Wendy Hudson, OWEB, written commun., October 21, 2013). Restoration projects range from removing nonnative plants to reconnecting side channels.

2. Environmental flows-The U.S. Army Corps of Engineers (USACE) operates 13 flood-control dams throughout the basin to reduce flood hazards to downstream communities. These dams alter the magnitude, frequency, and duration of flows throughout the year. To mitigate some of these changes, the USACE partners with The Nature Conservancy on "The Sustainable Rivers Project" to better manage downstream flow in order to benefit native fish, wildlife, and plants (The Nature Conservancy, 2013). "Environmental flows" are also specified in Willamette Basin Biological Opinion (National Marine Fisheries Service, 2008) as a key management tool for the recovery of endangered salmon stocks.

\section{Management of floodplain forests-} The Willamette River floodplain historically supported an extensive mosaic of riparian forests, which in turn provided shading and habitat for aquatic, riparian, avian, and terrestrial species. The area of riparian forests has decreased by about 80 percent since 1850 (Gregory and others, 2002a). These forests may experience even greater decreases in coming decades as older forests continue to age (David Hulse, University of Oregon, unpub. data) and channel stability limits coloniza- tion and establishment of early seral species (Cline and McAllister, 2012). Restoring native riparian vegetation is challenging and expensive, but enhancing natural processes supporting vegetation succession may provide opportunities to increase stand diversity and other ecosystem benefits.

4. Revetment modifications-Many reaches of the main stem Willamette River and its major tributaries have been stabilized with revetments, a general term for bank-protection structures that reduce erosion. In some places, modification or removal of revetments may permit channel migration and help create new landforms and habitats. Strategic implementation of this restoration practice would benefit from better knowledge of channel migration processes in relation to creating and modifying landforms and habitats, particularly with respect to presentday flow and sediment conditions.

\section{Reclamation of gravel mining sites-} The floodplains of the Willamette River and its major tributaries have numerous gravel extraction sites. Although some sites are at risk for possible capture by the river, others pose opportunities for restoration because they commonly occupy large tracts of land along the rivers.

Efficiently implementing these activities to establish an ecologically functional river corridor requires knowledge of the fluvial and ecologic processes that create and maintain landforms and habitats. This report summarizes current understanding of channel and floodplain landforms, vegetation, and habitat-forming processes along river corridors in the present-day Willamette River Basin (fig. 1), focusing on the Willamette River and its major salmon-bearing tributaries downstream of the USACE dams (fig. 2). This summary of present understanding also identifies key knowledge gaps, including several that are pertinent to floodplain restoration and conservation. This report has three main sections: 
1. Primer on the Willamette Geomorphic Floodplain - This section describes active channel and floodplain components, related controls and processes shaping these components, and pilot landform mapping by the U.S. Geological Survey (USGS).

2. Transformation of the Willamette Geomorphic Floodplain - Here, we summarize some of the key alterations to geomorphology in the basin, consequences of those changes for channels and vegetation, and likely future conditions.

3. Unanswered Science Questions and Next Steps - This section summarizes what we identify as four key questions regarding channels and floodplains that are relevant to restoration and conservation. It also suggests approaches for addressing these questions.

\section{The Willamette River Basin and Study Area}

The Willamette River drains $28,800 \mathrm{~km}^{2}$ of northwestern Oregon before joining the Columbia River near Portland, Oregon (fig. 1). It begins at the confluence of the Middle and Coast Fork Willamette Rivers near Eugene, Oregon, and then flows northward for $300 \mathrm{~km}$, added to by major tributaries from the Cascade Range, including the McKenzie $\left(3,450 \mathrm{~km}^{2}\right)$, Santiam $\left(4,660 \mathrm{~km}^{2}\right)$, and Clackamas Rivers $\left(2,450 \mathrm{~km}^{2}\right)$ (fig. 1).

This study focuses on the main stem Willamette River upstream of Newberg Pool and its major salmon-bearing tributaries downstream of the USACE flood-control dams (fig. 2). For the most part, these rivers have alluvial channels in which their beds and banks are composed of river-transported gravel, sand, and silt. These alluvial sections differ from the upstream and higher-gradient sections where the channel flows on or against bedrock for long stretches, and the low-gradient and tidally influenced sections of the main stem downstream of Newberg Pool and Willamette Falls. Within the alluvial section of focused study, the overall character of the Willamette River varies from from multithread channels with many active gravel bars in its upper reaches to a more stable, single-thread channel with fewer gravel bars in its lower reaches. Likewise, the Willamette's major tributaries vary along their lengths.

For this study, we divided the river corridors in the study area into nine valley segments to account for longitudinal differences in channel morphology and to help summarize constraints on habitat-forming processes (figs. 2 and 3). The main stem Willamette River was divided into three segments (upper, middle, and lower). Alluvial parts of the Coast Fork Willamette, Middle Fork Willamette, McKenzie, South Santiam, North Santiam, and Santiam Rivers are individual segments. Maps and descriptions of the valley segments are in appendix A. The morphological characteristics of each valley segment are distinct and relate to overall differences in geology, physiography, flow, sediments, and bank stability. 


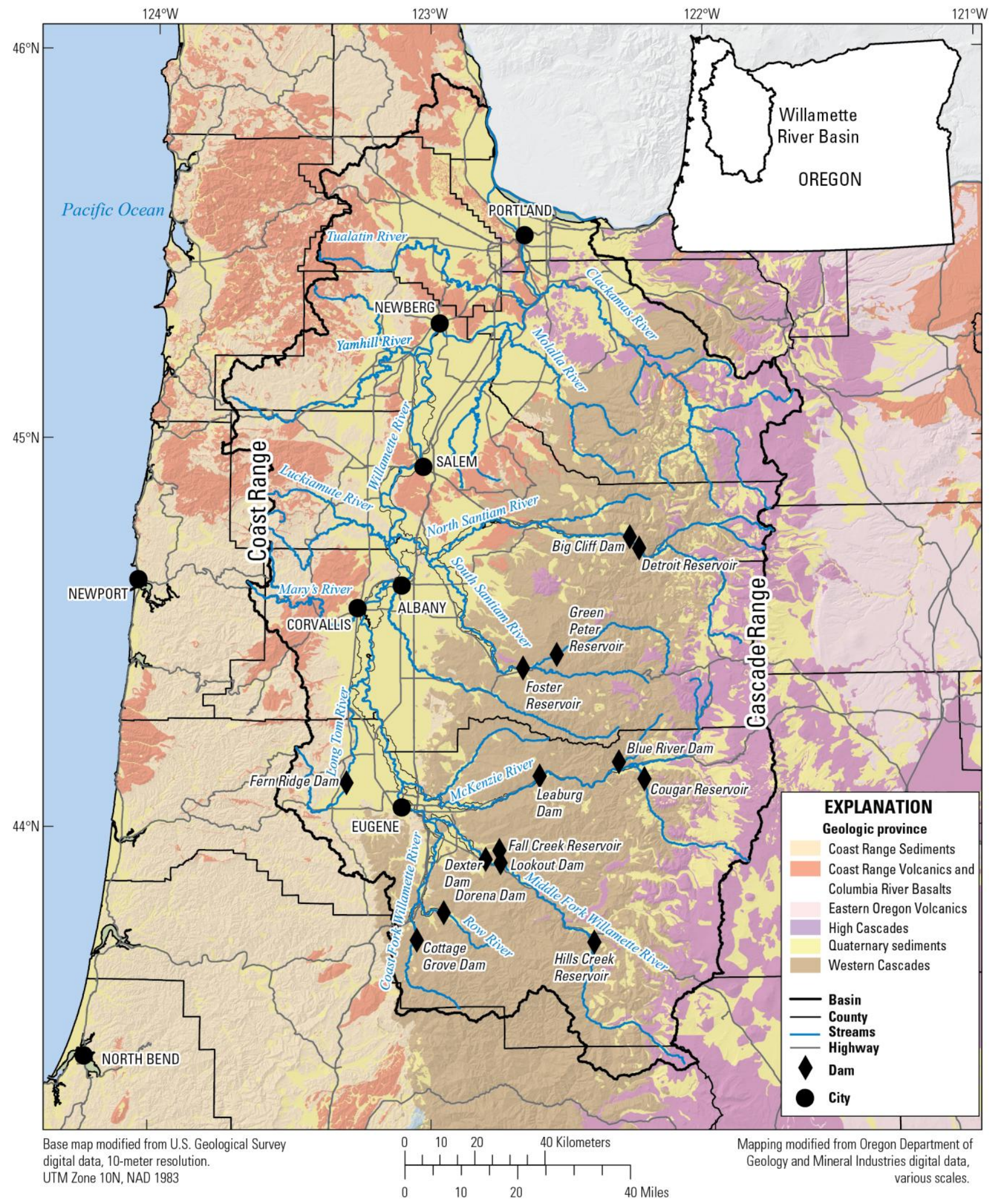

Figure 1. Map showing geology and topography of Willamette River Basin, Oregon. 


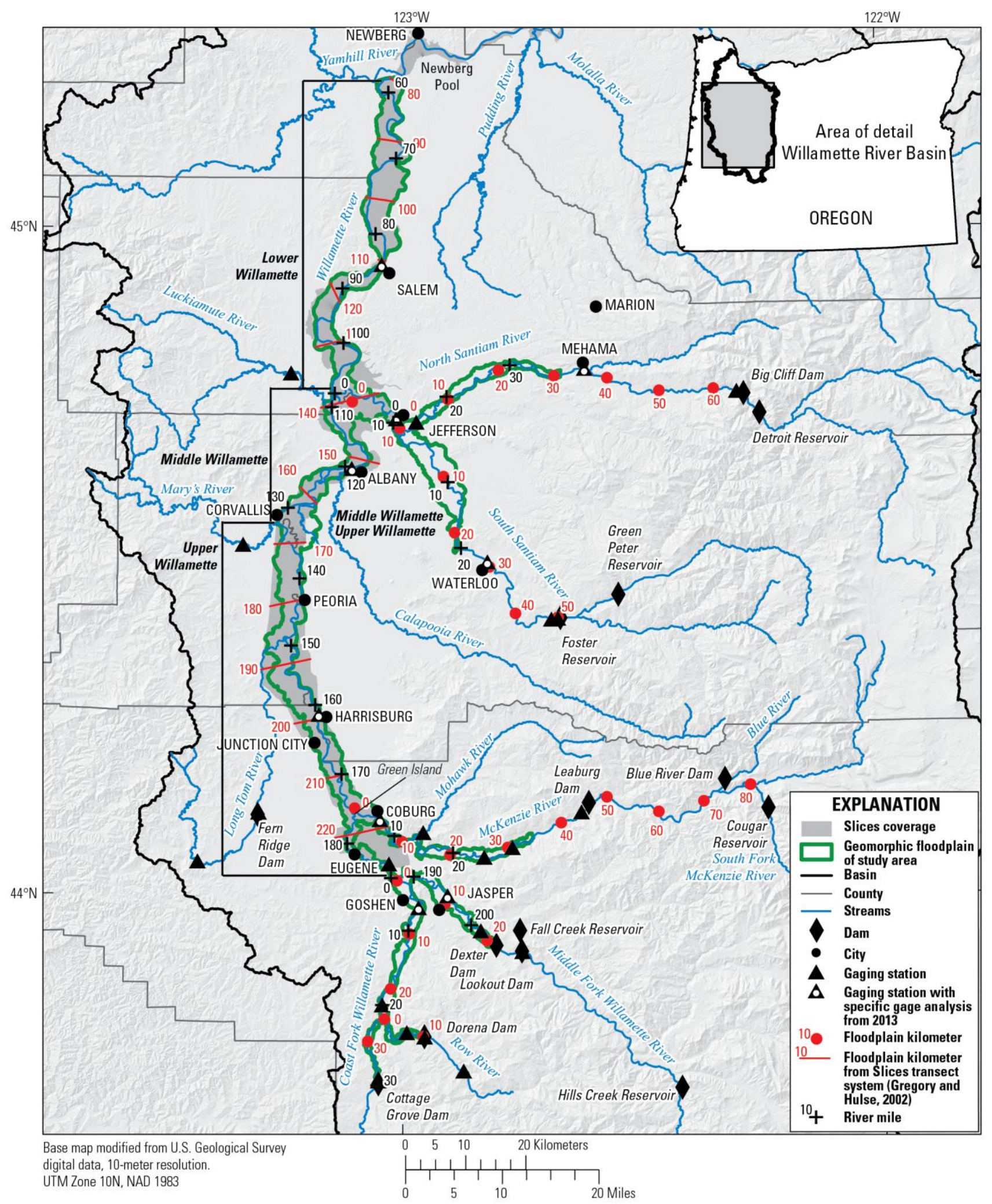

Figure 2. Map showing geomorphic floodplain study area for Willamette River and major tributaries draining the Cascade Range, Oregon. 


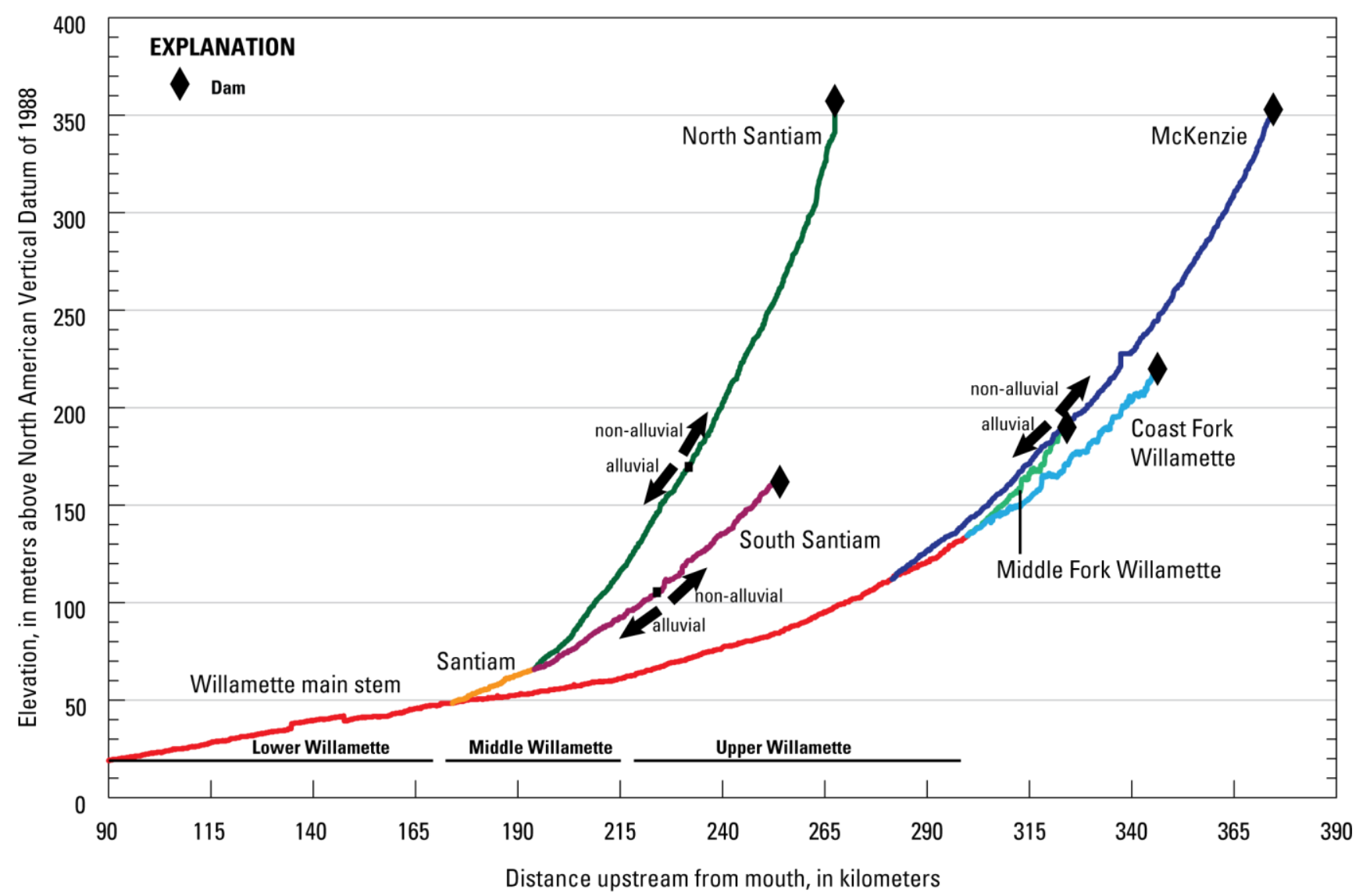

Figure 3. Longitudinal profiles showing Willamette River and major tributaries downstream of U.S. Army Corps of Engineers dams, Oregon. Distance from the mouth refers to river kilometer, as measured along the channel centerlines from Light Detection and Ranging (LiDAR). Elevation data were extracted from LiDAR and reflect water surface elevations at low flows with the exception of upstream of river kilometer 222 on Middle Fork Willamette River and river kilometer 216 on Coast Fork Willamette River where data were derived from U.S. Geological Survey 10-meter digital elevation models. See table 1 for data sources.

\section{Primer on the Willamette River Geomorphic Floodplain}

In this report, we focus on the "geomorphic floodplain" of the Willamette River and its major Cascade Range tributaries. The geomorphic floodplain comprises landforms and resultant physical habitats formed chiefly by fluvial geomorphic processes active during the Holocene climatic regime of the last 10,000 years. This process-based definition of the floodplain is distinct from regulatory definitions based on specific attributes such as inundation frequency and channel migration rates.

\section{Mapping the Geomorphic Floodplain}

We mapped the geomorphic floodplain at a scale of 1:10,000 for the Willamette River and its tributaries within the study area on the basis of high-resolution Light Detection and Ranging (LiDAR) topography, the distribution of Holocene floodplain deposits (O'Connor and others, 2001), floodplain soils (U.S. Department of Agriculture, 2012), and U.S. Geological Survey (USGS) 10-meter digital elevation data. Main stem river locations are referenced to the $1-\mathrm{km}-$ wide Slices transect system (Gregory and Hulse, 2002). Because tributaries presently are not included in the Slices framework, we developed a floodplain kilometer (FPKM) reference system 
for the tributaries by digitizing centerlines along the axis of the geomorphic floodplain and distributing points along the line at every kilometer. Numbering of the tributary FPKM begins at the mouth of each river (fig. 2), as with the Slices transects.

The resulting geomorphic floodplain for the main stem Willamette River closely follows the Holocene floodplain as mapped by O'Connor and others (2001). It is narrower than the floodplain defined by the limits of historical flood inundation (fig. 2) and used in the Slices framework. Some areas outside the geomorphic floodplain were inundated historically by large floods but they are generally underlain by older Pleistocene (more than 10,000 years old) deposits formed during ice-age climatic regimes. These relict features have different characteristics than landforms that are within the geomorphic floodplain and shaped, eroded, and deposited by the historical range of flooding.
Throughout this report, we show several illustrations of active channel and floodplain features. The mapping of these features was drawn from existing datasets, including aerial photographs and LiDAR topography collected during low flows (table 1). In 2012, the USGS developed these preliminary maps as part of a pilot project to develop a geomorphic inventory for Willamette Valley floodplains similar to the Ecosystem Classification completed for the lower Columbia River and floodplain (Simenstad and others, 2011; Lower Columbia Estuary Partnership, 2013). Major mapping units included floodplains and active channel surfaces, which then were separated into multiple levels according to their height above the water surface and topography. The pilot mapping focused on the main stem Willamette River from Corvallis to its confluence with the McKenzie River (approximately FPKMs 168-218) and near Half Moon Bend (FPKMs 159-161).

Table 1. Summary of aerial photography and topography data reviewed in this study and used as a basis for pilot landform mapping for the Willamette River Basin, Oregon.

[1939 aerial photographs were georeferenced for this study. Other spatially-registered aerial photography is publically available. Abbreviations: USACE, U.S. Army Corps of Engineers; UO, University of Oregon; USGS, U.S. Geological Survey; USDA, U.S. Department of Agriculture; LiDAR, Light Detection and Ranging; DEM, digital elevation model; DOGAMI, Oregon Department of Geology and Mineral Industries]

\begin{tabular}{lllll}
\multicolumn{1}{c}{ Data set } & Year & Resolution & Source & Repository \\
\hline Aerial photography & 1939 & $1: 10,200$ & USACE & UO \\
& 1994 & 1 -meter & USGS & USGS \\
& 2000 & 1 -meter & USGS & USGS \\
& 2005 & 1 -meter & USDA & USDA \\
& 2009 & 0.5 -meter & USDA & USDA \\
& 2011 & 1 -meter & USDA & USDA \\
LiDAR survey & 2008 & 1 -meter & DOGAMI & DOGAMI \\
10-meter DEM & Varies & 10 -meter & USGS & USGS \\
\hline
\end{tabular}




\section{Geomorphic Floodplain Components}

A geomorphic floodplain can be divided into two main components: (1) the active channel area with frequent scour, bed-material transport, and sediment deposition during floods and (2) the floodplain area with occasional overbank inundation and mainly fine sediment deposition, but locally subject to avulsions and side-channel incision (figs. 4-6). The boundary between active channel and floodplain surfaces often can be indistinct because the fluvial processes shaping these surfaces and their underlying sediments vary longitudinally and laterally along the main stem Willamette River and its tributaries with modest changes in floodplain elevation.

Active channel features include the primary channel, secondary channel features (such as side channels, alcoves, sloughs, and swales), inchannel elements such as pools and riffles, and in-channel and channel-flanking gravel bars with sparse-to-dense vegetation (figs. 5 and 6). Active channel surfaces can be distinguished by flowmodified surfaces (Church, 1988) and primarily are made of bed-material sediment (sand to cobble-sized particles) transported as bedload during floods. Each of these features has distinct physical characteristics and ecological roles for aquatic, riparian, avian, and terrestrial species (Landers and others, 2002). For example, active channel habitats have coarse bed material and are more frequently disturbed, whereas side channels have finer bed material and often are refuges during high flows for aquatic species. Secondary channel features vary in their connectivity with the primary channel and distribution throughout the study area. Similarly, gravel bars are present throughout the Willamette River and its major tributaries, but vary considerably in area, volume, sediment size, and vegetation cover.

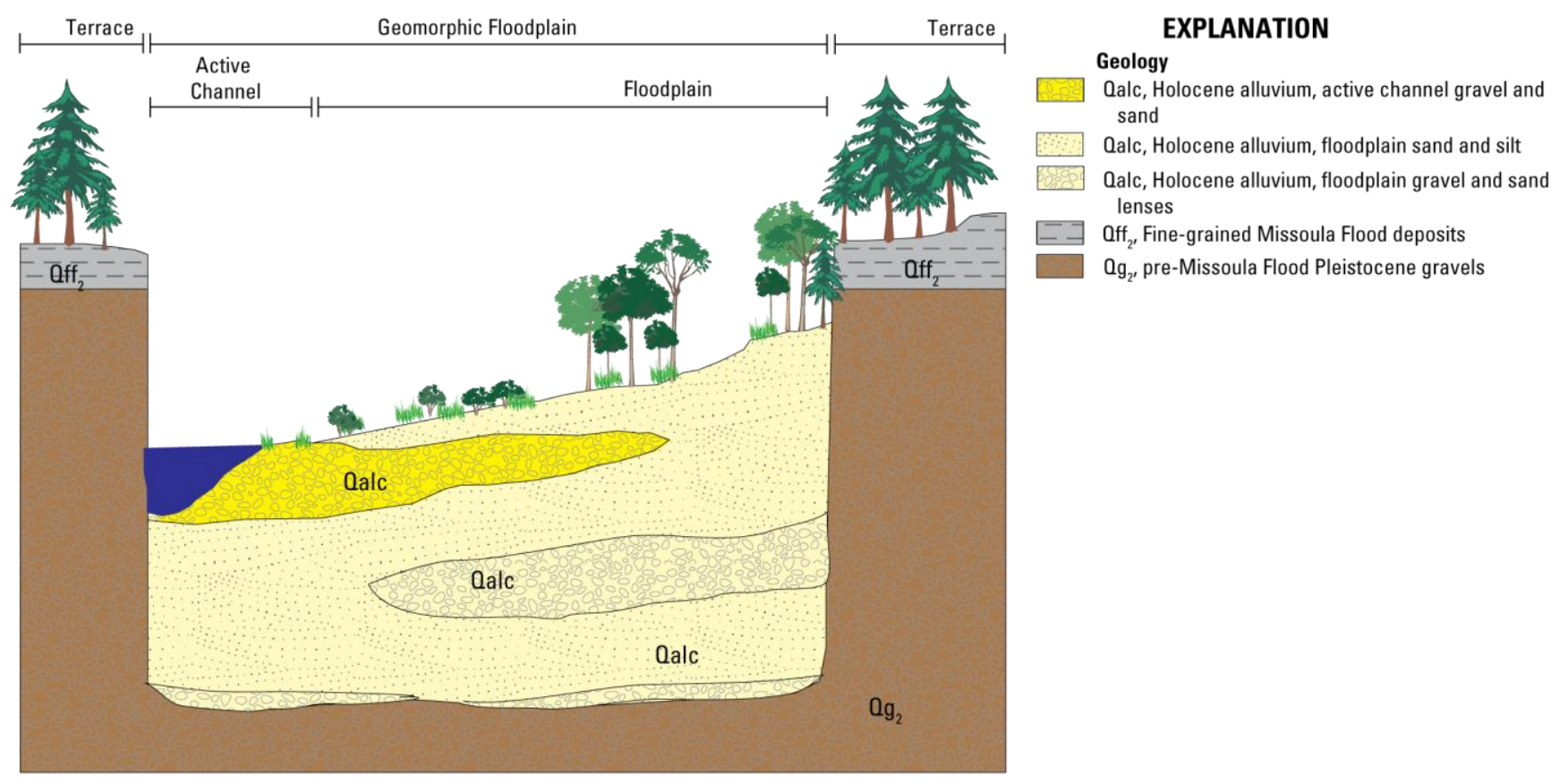

Figure 4. Generalized cross section (not to scale) showing channel features and geological units of the Willamette River Valley, Oregon. Geomorphic floodplain corresponds to Holocene floodplain and is inset within older Pleistocene deposits. Where the river flows along the floodplain margins, it impinges on resistant Pleistocene gravels $\left(\mathrm{Qg}_{2}\right)$ that underlie Missoula Flood deposits (Qff 2$)$. Geological units are from O'Connor and others (2001). 
Floodplain surfaces typically are higher than active channel areas, but include a continuum of secondary channels, including sloughs, swales, and tie channels connecting floodplain lakes to the primary channel. These floodplain channel features are intermixed with natural levees (relatively high elevation sandy deposits near channel margins) and other higher elevation areas, resulting in patchy, diverse riparian habitats (figs. 5 and 6). Floodplain surfaces are mantled

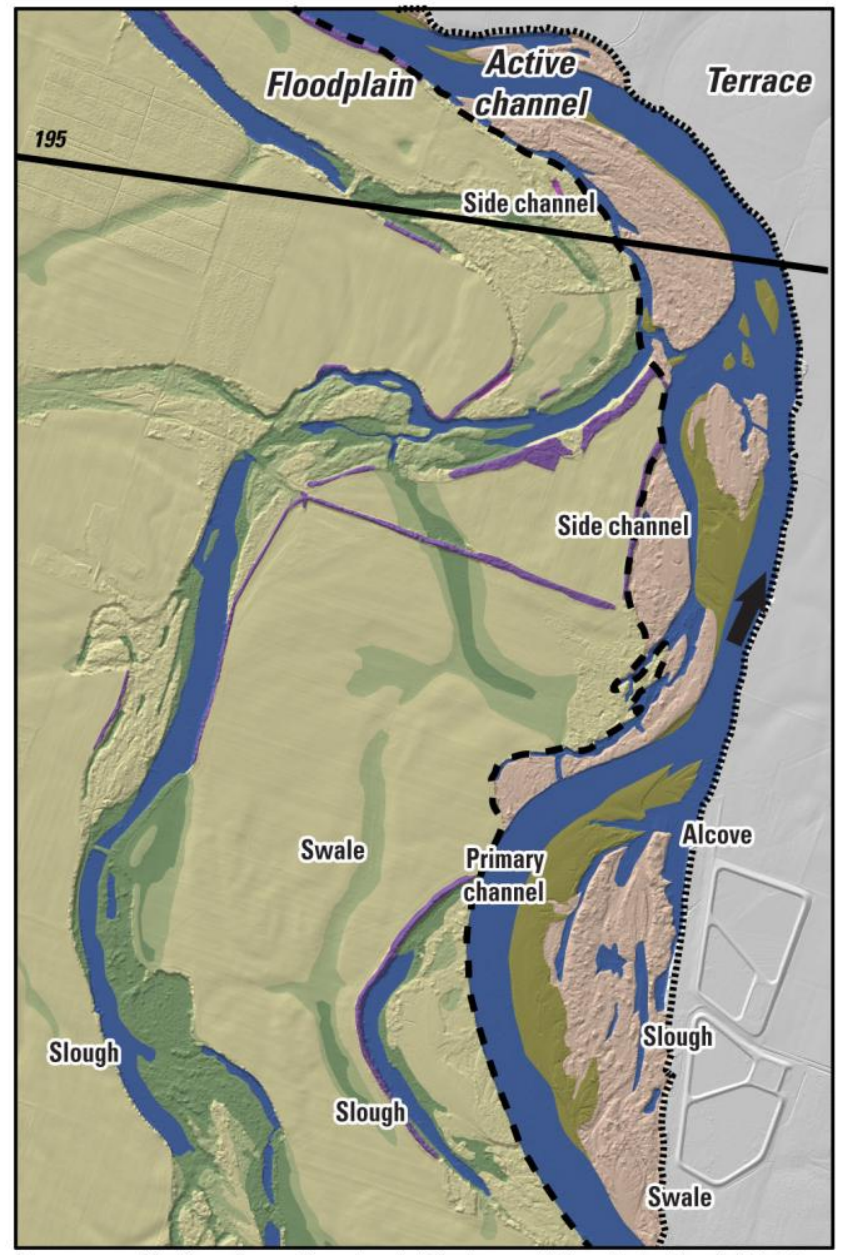

Base map modified from Oregon Department of Geology and Mineral Industries digital data 1-meter resolution. UTM Zone 10N, NAD1983 with finer sand, silt, and clay transported as suspended load and deposited in slower velocity environments. Floodplain swales and sloughs provide high-flow refugia and abundant food resources for juvenile fish (Junk and others, 1989; Sommer and others, 2001; Colvin and others, 2009; Bellmore and others, 2013), and habitat for red-legged frogs, Oregon chub, migratory birds, and waterfowl (Gregory and others, 2007).

Figure 5. Examples of channel and floodplain landforms along the Willamette River near floodplain kilometer 195, Harrisburg, Oregon. 


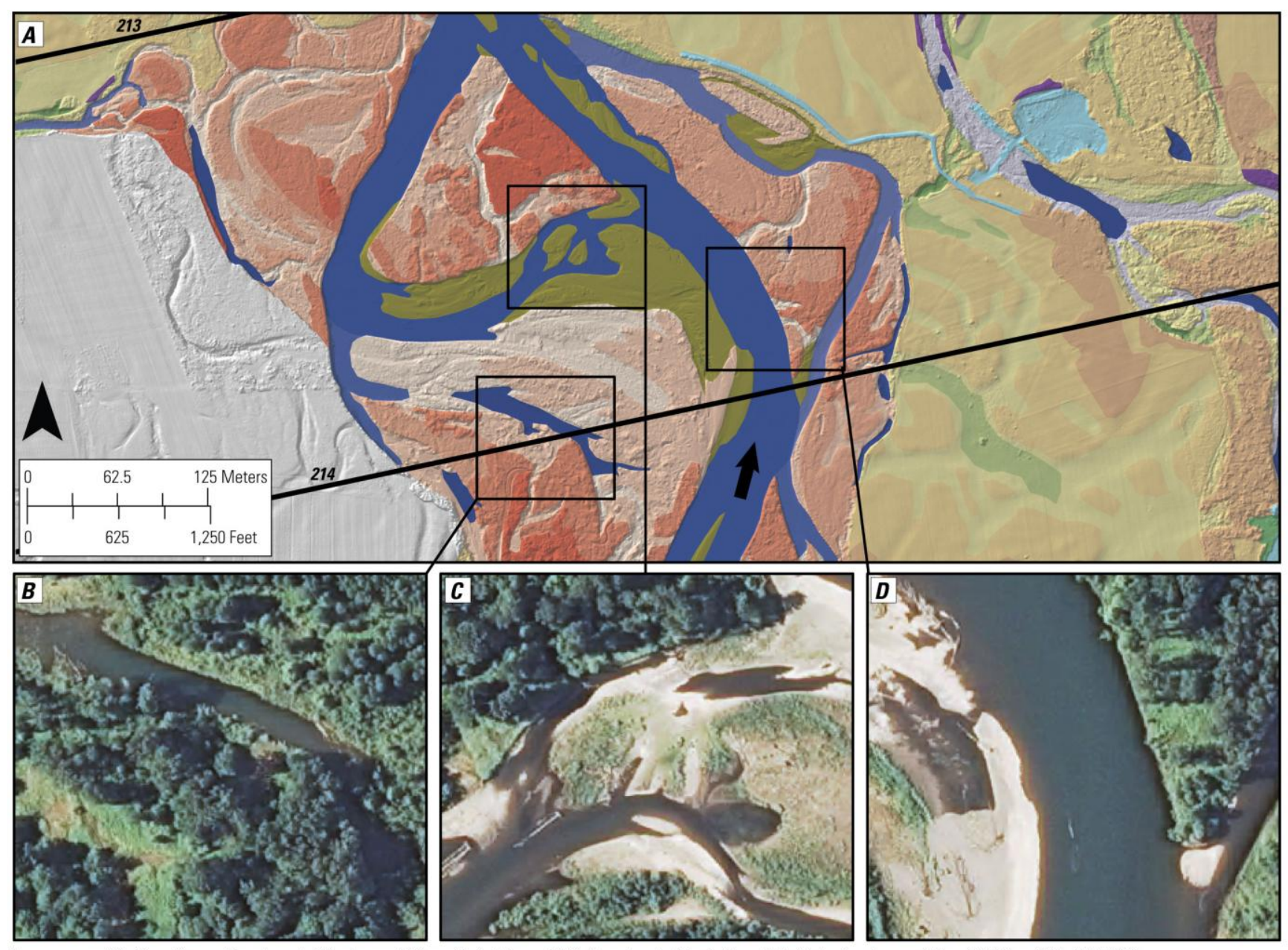

Base maps modified from Oregon Department of Geology and Mineral Industries and U.S. Department of Agriculture digital data, 1-meter resolution. UTM Zone 10N, NAD 1983

\section{EXPLANATION}

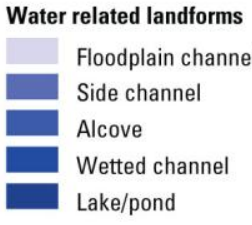

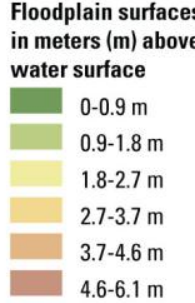

\begin{tabular}{l}
$\begin{array}{l}\text { Gravel bar, } \\
\text { in meters }(\mathbf{m}) \text { above } \\
\text { water surface }\end{array}$ \\
Active bar \\
$0-0.9 \mathrm{~m}$ \\
$0.9-1.8 \mathrm{~m}$ \\
$1.8-2.7 \mathrm{~m}$ \\
$2.7-3.7 \mathrm{~m}$ \\
3.7- \\
\hline
\end{tabular}

Modifier

Modifiered

Artificial

214 Floodplain

kilometer

from Slices

transect system (Gregory and Hulse, 2002)

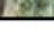


As floods overtop channel banks, stream velocity decreases, allowing fine sediments and other materials to deposit in the low-energy floodplain environment away from the channel. Inundation, deposition, and erosion patterns vary depending on flood magnitude and floodplain characteristics, such as height relative to the active channel, roughness, and topography. These differences, in turn, relate to the variations in density, connectivity, and elevation of secondary channel features on floodplain surfaces throughout the study area.

Maps of the Willamette River floodplain near FPKMs 134 and 208 show some of this var- iation (fig. $7 A-B$ ). Floodplain surfaces near FPKM 134 are mostly 4-6 m higher than the low water surface and rarely inundated (fig. 7A). Here, floodplain secondary channel features are primarily wide swales. By contrast, upstream at FPKM 208, where the floodplain is lower relative to the channel elevation and more frequently inundated, the overall density and diversity of secondary channel features are much greater. Here, numerous side channels, sloughs, and swales are generally less than $2 \mathrm{~m}$ higher than the low water surface (fig. $7 B$ ).

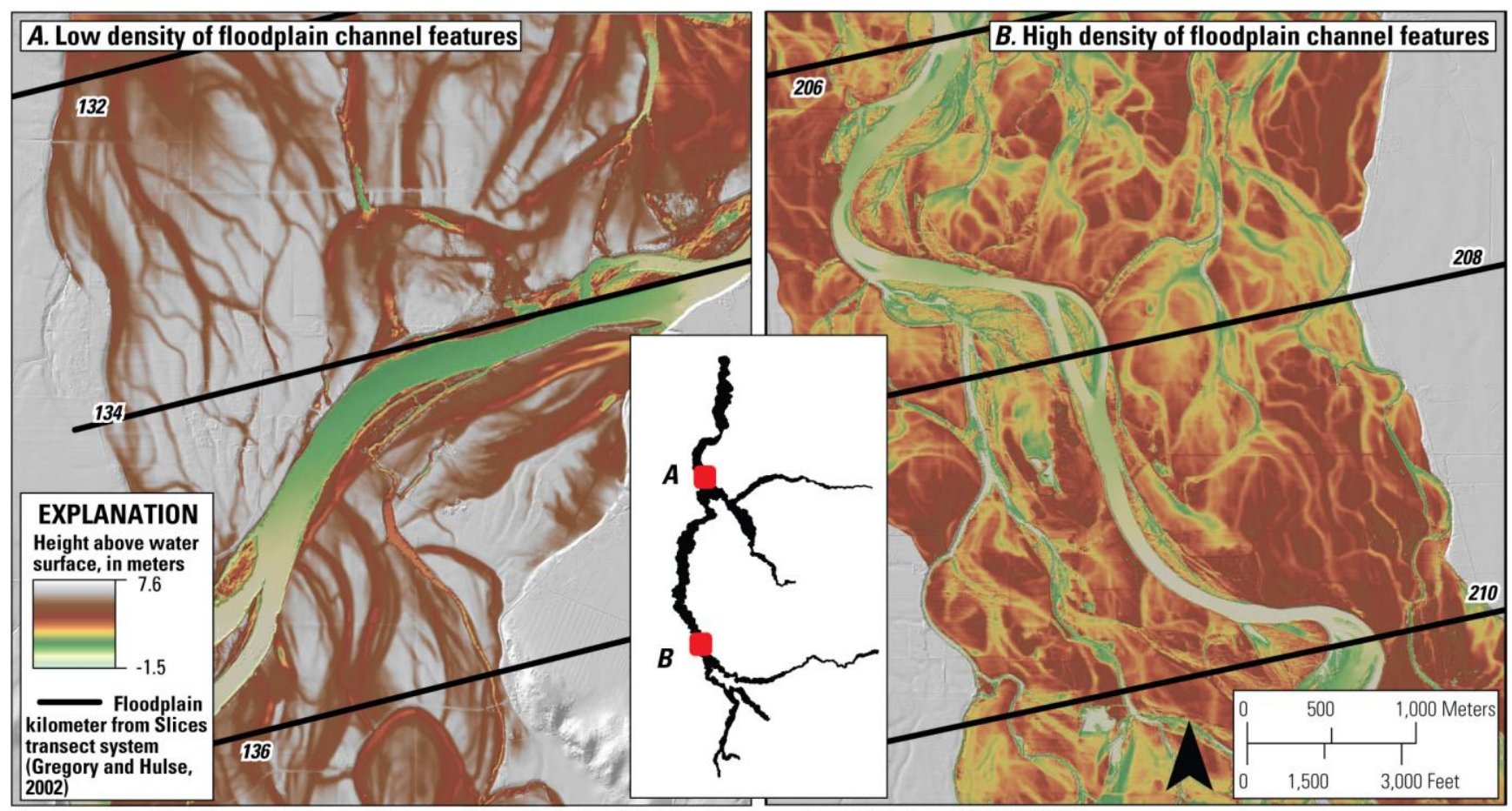

Base map modified from Oregon Department of Geology and Mineral Industries digital data, 1-meter resolution. UTM, Zone 1ON, NAD 1983

Figure 7. Examples of floodplain topography, sloughs, and swales on the Willamette River, Oregon. A. Lower Willamette River near floodplain kilometer 134, Buena Vista, Oregon, has relatively high floodplain elevations relative to water surface and lower density of floodplain channel features. $B$. Upper Willamette River near floodplain kilometer 208, Junction City, Oregon, has low floodplain elevations relative to water surface and high density of floodplain channel features. 
Riparian Vegetation. Many surfaces within the geomorphic floodplain are vegetated with species dependent on fluvial processes and landforms. In this report, we use the term "riparian forest" in referring to galleries of mature trees growing along the rivers and "riparian vegetation" to generally describe herbaceous and woody plants of different age classes in floodplain and active channel areas. Riparian forests increase bank stability, shade streams, and provide large wood and organic matter inputs that are key building blocks of riverine habitats and food webs. Different plants thrive on various active channel and floodplain features because each plant has traits and life histories suitable to the different sediment characteristics and dominant fluvial processes shaping these features. For instance, conifers grow on the Willamette River Basin's uplands and along transition zones between upland and alluvial sections on the tributaries, where channels are more confined and inundation is less frequent. In active alluvial sections, "pioneer" species like black cottonwood, willow, and white alder as well as sedges and rushes can colonize recently deposited, lowelevation gravel bars that lack shade (fig. 8).

Because of the coupling between landforms and stand initiation for some pioneer species, their ages often are positively related (Cline and McAllister, 2012). Sites with younger vegetation generally occur along the upper segment of the

\begin{tabular}{llll}
$\begin{array}{l}\text { Mixed riparian } \\
\text { forest }\end{array}$ & $\begin{array}{l}\text { Cottonwood- } \\
\text { dominated forest }\end{array}$ & Pioneer vegetation & $\begin{array}{l}\text { Mixed riparian } \\
\text { forest }\end{array}$ \\
$\begin{array}{l}\text { Oregon ash, bigleaf } \\
\text { maple, and black } \\
\text { cottonwood }\end{array}$ & $\begin{array}{l}\text { Black cottonwood, } \\
\text { Oregon ash, bigleaf } \\
\text { maple }\end{array}$ & $\begin{array}{l}\text { Black cottonwood, } \\
\text { willow, white alder, } \\
\text { and herbaceous } \\
\text { vegetation }\end{array}$ & $\begin{array}{l}\text { Oregon ash, bigleaf } \\
\text { maple, and black } \\
\text { cottonwood }\end{array}$ \\
\hline $\begin{array}{l}\text { High elevation } \\
\text { floodplain }\end{array}$ & $\begin{array}{l}\text { Low elevation } \\
\text { floodplain }\end{array}$ & Bar & $\begin{array}{l}\text { Wetted } \\
\text { channel }\end{array}$
\end{tabular}

Figure 8. Generalized cross section showing variation in native vegetation with floodplain topography of the Willamette River Basin, Oregon.
Willamette River where freshly formed secondary channel features and gravel bars are more common (Fierke and Kauffman, 2006b). Older, higher-elevation floodplain surfaces tend to have mature black cottonwood, Oregon ash, and bigleaf maple. On these floodplain surfaces, bigleaf maple and Oregon ash vary with site characteristics such as shade and soil moisture.

Vegetation seral stages and patch heterogeneity all vary longitudinally along the presentday floodplains of the Willamette River and its major tributaries (fig. 9). In some reaches such as the Middle Fork Willamette River (fig. 9A), densely vegetated relict gravel bars commonly extend from the low-water line to the floodplain In other areas, such as the upper segment of the Willamette River, short woody vegetation and shrubs occur on some lower-elevation bars, whereas dense mature trees dominate higherelevation bars (fig. 9B). Similar patterns of vegetation occur along the North Santiam River, where recently reworked bars are nearly devoid of vegetation, but older surfaces have varying density and maturity of vegetation based on local site conditions and patterns of historical channel change (fig. 9C). The width of the riparian forest corridor also varies throughout the study area, as nearly every river in the study area has sections flanked by little-to-no riparian forest and other sections where riparian forests extend for more than $1 \mathrm{~km}$ in width (appendix A). 


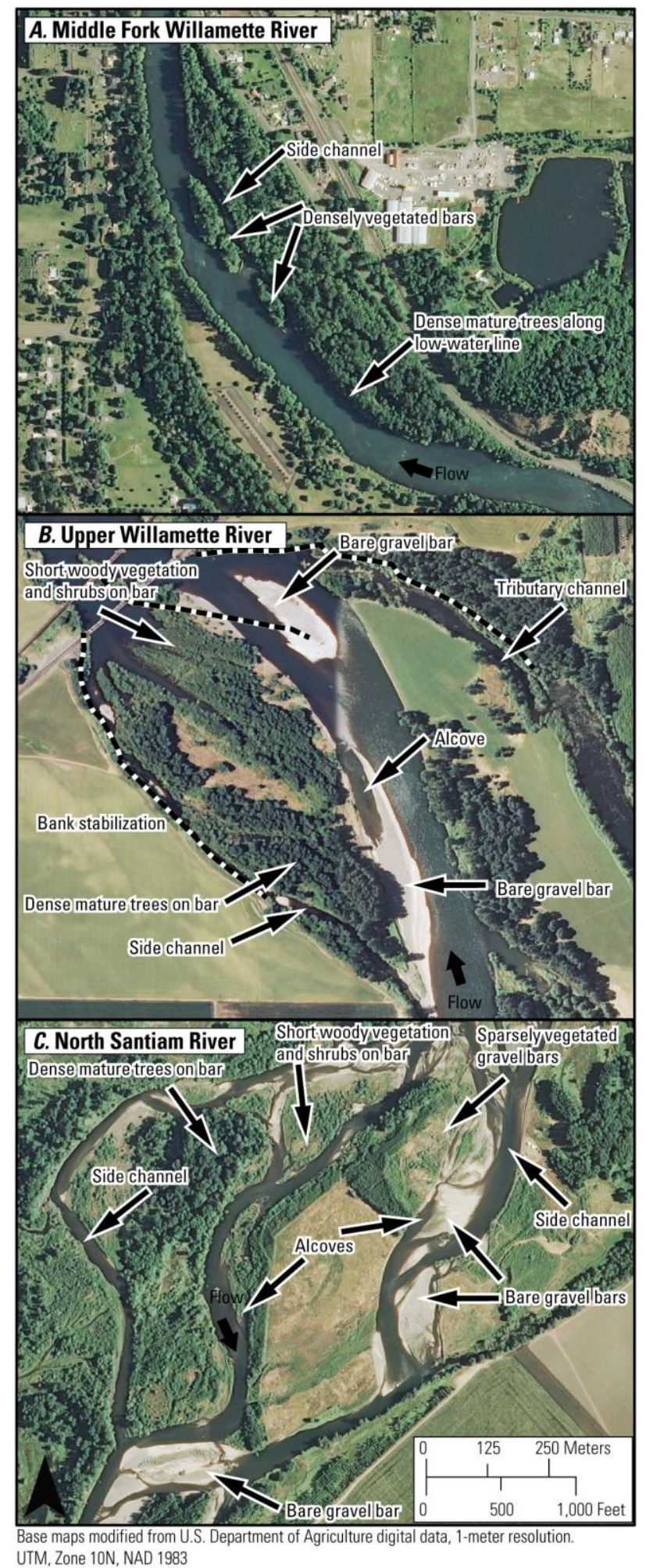

Figure 9. Comparison of active channel features and vegetation in the Willamette River Basin, Oregon. A. Middle Fork Willamette River. B. Upper segment of Willamette River. C. North Santiam River.

\section{Controls and Processes Shaping the Geo- morphic Floodplain and Riparian Vegetation}

The conceptual model guiding our current understanding of floodplain and habitat formation in the Willamette Valley is that inherent factors such as geology, hydrology, physiography, and climate establish first-order controls on landforms, habitats, and vegetation (fig. 10). These overarching controls affect flooding and the transport of sediment and large wood.

\section{Geology}

Two rugged and deeply dissected mountain ranges form the boundaries of the Willamette River Basin. The Cascade Range and its Tertiary and Quaternary volcanic and volcaniclastic rocks form the eastern part of the watershed (fig. 1). The Coast Range and its uplifted Tertiary marine sandstones and volcanic rocks form the western part of the basin and underlie most of the valley itself (fig. 1). The taller and broader Cascade Range contributes most of the flow and sediment, particularly bed material, to the Willamette River, primarily from major tributaries, such as the Middle Fork Willamette, McKenzie, and Santiam Rivers.

The Willamette Valley is a broad alluvial plain composed primarily of Quaternary alluvium and ranges up to $50 \mathrm{~km}$ wide. During the Pleistocene ice ages of the last 2.5 million years, braided rivers emanating from the Cascade Range deposited sands and gravels, forming valley fill sediments and alluvial fans that displaced the river westward (O'Connor and others, 2001). Between 20,000 and 15,000 years ago, dozens of floods from Glacial Lake Missoula backfilled the Willamette Valley from the Columbia River, capping the Pleistocene valley fill with up to 30 $\mathrm{m}$ of sand, silt, and (fig. 1; O'Connor and others, 2001; O'Connor and Benito, 2009). 

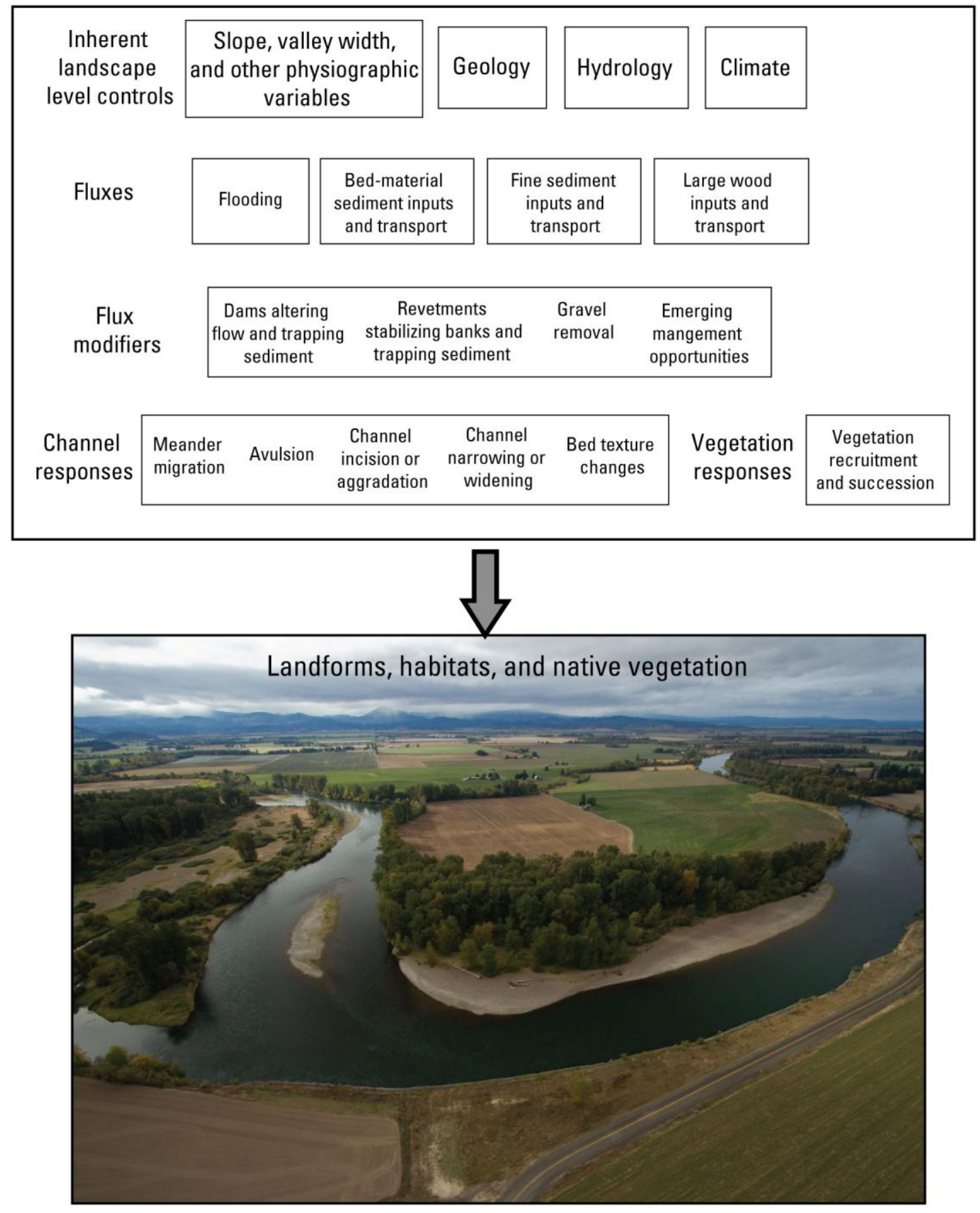

Figure 10. Conceptual model of dominant processes shaping landforms and habitats of Willamette River Basin, Oregon, floodplains. Photograph of the Willamette River provided by Freshwaters Illustrated. 
Since the Missoula Floods, the Willamette River has incised through these deposits and older Cascade Range sands and gravels, forming a Holocene (less than 10,000 years old) floodplain that is up to $2 \mathrm{~m}$ wide and inset 3-35 m below the Pleistocene deposits underlying much of the main valley floor (fig. 4; O'Connor and others, 2001). The Holocene floodplain has many channel and floodplain features, ranging from recent point-bar and active channel deposits to forested floodplains. This Holocene floodplain essentially constitutes the geomorphic floodplain.

The location of the Willamette River and its major tributaries relative to the Holocene floodplain and older terraces has implications for bank stability and channel change (Wallick and others, 2006). The Willamette River and its major tributaries are mostly flanked on both sides by Holocene alluvium (O'Connor and others, 2001). Because these sediments are easily erodible, channels can adjust their depths and locations. Locally, however, channels abut older and more indurated bank materials along the floodplain margins that are naturally resistant to lateral channel migration (fig. 4). The most extensive of these are the consolidated Pleistocene gravels that underlie Missoula Flood sediments. Other resistant geological units include Tertiary marine sandstones that border the Willamette River near Albany (FPKM 110), and Tertiary volcanic deposits that form steep hillslopes along the Willamette River near Salem (FPKM 70) and various sections of the tributaries (appendix A).

\section{Hydrology}

The Willamette Valley has a Mediterranean climate, with cool, wet winters and warm, dry summers. The valley floor receives $1,000 \mathrm{~mm} / \mathrm{yr}$ of precipitation, mainly as rainfall during the winter. Headwater reaches in the Cascade Range receive as much as 2,600 mm/yr of precipitation, which falls as rain and snow (Oregon State University, 2013a), also mainly in the winter. Peak flows generally are in winter, with major floods typically resulting from basinwide rain-on-snow events (Harr, 1981). Although precipitation is greatest along the crest of the Cascade Range, in this area rainfall and snowmelt infiltrate through the young, porous volcanic rocks of the High Cascades geologic province, supporting steady year-round discharge at large spring complexes in this region (Stearns, 1928; Tague and Grant, 2004; Jefferson and others, 2006). In contrast, the older, less-permeable Western Cascades are steep and highly dissected, causing stream discharge to be much more responsive to storm runoff than in the High Cascades. Streamflows are measured throughout the basin at several USGS gaging stations (fig. 2; table 2).

Streamflows in the Willamette River Basin are regulated by the 13 USACE dams constituting the Willamette Valley Project. Twelve of these dams and reservoirs are at key locations on Western Cascades tributaries to minimize peak flows (fig. 1). The 13th dam is on the Long Tom River, a tributary draining the Coast Range. Dam construction was completed between 1942 and 1969 on the Western Cascades tributaries and in 1941 on the Long Tom River (Oregon Water Resources Department and U.S. Army Corps of Engineers, 1998). These projects are primarily operated for flood control, but other authorized uses include irrigation, recreation, water supply, and in some cases, hydropower (U.S. Army Corps of Engineers, 1969). These flood-control operations reduce the frequency and magnitude of flood peaks and increase summer flows (U.S. Army Corps of Engineers, 1969; Gregory and others, 2007; Risley and others, 2010, 2012). Many smaller dams and projects impound and divert flow throughout the Willamette River Basin (Payne, 2002), but they generally do not substantially affect streamflows.

Peak flows may also be affected by urbanization and timber harvest. Relative to the river regulation imposed by the USACE Willamette Project, however, flow changes related to land uses are probably minor (Grant and others, 2008). Recent trends of decreasing peak flows also are attributable to declining snowpack (Luce and Holden, 2009; Jefferson, 2011) and dimin- 
Table 2. Key U.S. Geological Survey streamflow gaging stations for Willamette River and major tributaries, Oregon.

[Years of record may include periods where no data was recorded. Abbreviations: ID, identification; FPKM, floodplain kilometer from 2008 centerline; --, gage is not used in specific gage analysis]

\begin{tabular}{|c|c|c|c|c|c|}
\hline Gage name & Gage ID & Record period & $\begin{array}{l}\text { Years of } \\
\text { record }^{*}\end{array}$ & FPKM & $\begin{array}{c}\text { Specific gage } \\
\text { analysis }\end{array}$ \\
\hline \multicolumn{6}{|c|}{ Main-stem Willamette River } \\
\hline Willamette River at Springfield & 14158000 & $1911-1957$ & 46 & 226 & -- \\
\hline Willamette River at Harrisburg & 14166000 & $1944-2012$ & 68 & 199 & Figure $22 G$ \\
\hline Willamette River at Corvallis & 14171600 & 2009-2012 & 3 & 165 & -- \\
\hline Willamette River at Albany & 14174000 & $1892-2012$ & 120 & 151 & Figure $22 H$ \\
\hline Willamette River at Salem & 14191000 & 1909-2012 & 103 & 110 & Figure $22 I$ \\
\hline \multicolumn{6}{|c|}{ North, South, and main-stem Santiam River Basins } \\
\hline North Santiam River near Mehama & 14183000 & 1905-2012 & 107 & 35.4 & Figure $22 A$ \\
\hline North Santiam River at Greens Bridge, near Jefferson & 14184100 & 1964-2012 & 48 & 3.6 & -- \\
\hline South Santiam near Foster & 14187000 & $1973-2012$ & 39 & 48.8 & -- \\
\hline South Santiam River at Waterloo & 14187500 & $1905-2012$ & 107 & 29.1 & Figure $22 B$ \\
\hline Santiam River at Jefferson & 14189000 & $1907-2012$ & 105 & 8.0 & Figure $22 C$ \\
\hline \multicolumn{6}{|c|}{ McKenzie River Basin } \\
\hline McKenzie River below Leaburg Dam, near Leaburg & 14163150 & 1989-2012 & 23 & 44.3 & -- \\
\hline McKenzie River near Walterville & 14163900 & 1989-2012 & 23 & 30.8 & -- \\
\hline McKenzie River near Springfield & 14164000 & $1905-1915$ & 10 & 25.7 & -- \\
\hline McKenzie River above Hayden Bridge, at Springfield & 14164900 & $2007-2012$ & 5 & 13.8 & -- \\
\hline McKenzie River near Coburg & 14165500 & $1944-2011$ & 67 & 4.5 & Figure $22 F$ \\
\hline \multicolumn{6}{|c|}{ Coast and Middle Fork Willamette River Basins } \\
\hline Middle Fork Willamette River near Dexter & 14150000 & $1946-2012$ & 66 & 18.1 & -- \\
\hline Middle Fork Willamette River at Jasper & 14152000 & $1905-2012$ & 107 & 9.7 & Figure $22 D$ \\
\hline Coast Fork Willamette River below Cottage Grove Dam & 14153500 & 1939-2012 & 73 & 37.1 & -- \\
\hline Coast Fork Willamette River near Saginaw & 14157000 & $1925-1951$ & 26 & 22.8 & -- \\
\hline Coast Fork Willamette River near Goshen & 14157500 & $1905-2012$ & 4.8 & 9.3 & Figure $22 E$ \\
\hline
\end{tabular}


ished frequency and magnitude of extreme precipitation events (Mass and others, 2011).

\section{Flooding}

Flooding shapes landforms, habitat, and vegetation patterns along river corridors in the Willamette River Basin (fig. 10). The capacity of floods to form and modify channels and floodplains is dictated largely by interactions between flood magnitude and channel geometry, and resulting local hydraulics and patterns of sediment erosion and deposition. Stream velocity and sheer stress can be highly variable, but generally increase with channel slope and water depth. Complicating the relations between floods and geomorphic consequences is the nonlinear behavior of erosion and sediment transport in relation to stream velocity and sheer stress.

The effectiveness of floods to modify channels and floodplains is undefined for the study area, but, in other Pacific Northwest gravel-bed rivers, geomorphically effective flows are those that attain bankfull levels and typically have recurrence intervals exceeding 1 year (Andrews, 1983, 1984).

\section{Bed-Material Sediment Inputs and Transport}

Bed material - sand, gravel, and cobbles - is a primary building block of active channel features in the Willamette River Basin. Bed material is supplied to channels from hillslopes and local bank erosion. As a river transports gravel and other bed material, these particles fracture, lose mass, and become smaller by attrition, resulting in downstream fining of bed material. Attrition also reduces overall bed-material flux because it converts some bed material to fine sediment that is then transported as suspended load higher in the water column.

In the main stem Willamette River, the ultimate source of most bed-material sediment is from the major tributaries draining the Western Cascades (O'Connor and others, in press). Bedmaterial supply is greatest immediately downstream of the main stem confluences with the
McKenzie and Santiam Rivers, and then diminishes downstream because of attrition. Large amounts of bed material also are produced by the tributaries draining the Coast Range, but little of this enters the main stem Willamette River as bed material because this material is chiefly soft sandstone clasts, which rapidly degrade to sand and silt after travelling short distances

(O'Connor and others, in press).

In river channels, bed-material erosion, transport, and deposition strongly influence landforms, habitats, and vegetation (fig. 10). Bedmaterial particles are transported along the channel bed during high flows and locally build riffles and bars. Bed-material transport is determined by the relative balance between a river's bed-material sediment supply and its transport capacity, or the "maximum load a river can carry" (Gilbert and Murphy, 1914, p. 35). Transport capacity is determined by channel hydraulics and sediment size, and generally increases with water depth, channel slope, and discharge (Wilcock and others, 2009). Reaches where bed-material inputs are greater than transport capacity have greater areas of gravel bars and higher rates of lateral migration (Church, 2006; O'Connor and others, in press). Reaches where bed-material supply is less than transport capacity tend to have fewer gravel bars, lower rates of lateral migration, and fewer secondary channels, and may locally flow on bedrock (O'Connor and others, in press).

\section{Large Wood Delivery and Transport}

Large wood affects channel and habitat conditions at multiple scales, ranging from forming individual habitat patches to controlling broadscale channel and floodplain patterns at reach scales (Keller and Swanson, 1979; Sedell and Froggat, 1984; Harmon and others, 1985; Gregory and others, 2002a; Collins and others, 2012). This is true especially for streams in the temperate Pacific coastal region, where interactions between transported wood, riparian forests, and channel and floodplain dynamics influence phys- 
ical and biological processes at different temporal and spatial scales.

As summarized by Collins and others (2012), in Pacific Northwest river systems, large wood jams serve as hard points in an otherwise erodible, alluvial floodplain. They can help stabilize bars and islands, enabling riparian forests to be established. Channel-spanning blockages of large wood and sediment also redirect flow toward the floodplain, triggering avulsions and amplifying lateral migration that recycles and modifies adjacent floodplain surfaces. Together, these processes can create a "patchwork floodplain" of bars, islands, secondary channels, and floodplains of varying elevation and vegetation assemblages (Montgomery and Abbe, 2006). At finer scales, individual wood pieces provide substrates for benthic macroinvertebrates and cover for fishes and other aquatic organisms. Large wood pieces can also focus scour and deposition, create variable hydraulic and substrate environments, and increase the diversity and complexity of local habitats.

\section{Alluvial Channel Reponses to Flooding and Sedi- ment Transport}

Alluvial channels respond to flooding and bed-material fluxes by adjusting their geometry, substrates, and styles and rates of channel migration. Geometry changes can include adjustments in channel width and depth as well as aggradation and incision. Substrate changes can include overall bed coarsening, fining, or armoring (in which a coarse surface layer of bed-material sediment develops). All these adjustments, in turn, can occur locally or at the reach scale and may affect active channel and floodplain landforms, their connectivity with main and secondary channels, and associated habitats.

The Willamette River and its major tributaries draining the Cascade Range move laterally across their floodplains by gradual lateral meander migration and abrupt channel avulsions. Lateral meander migration owes to progressive growth and translation of meander bends, resulting from gravel bar expansion on one bank and erosion on the opposite bank (Dietrich and Smith, 1983). Meander migration increases with

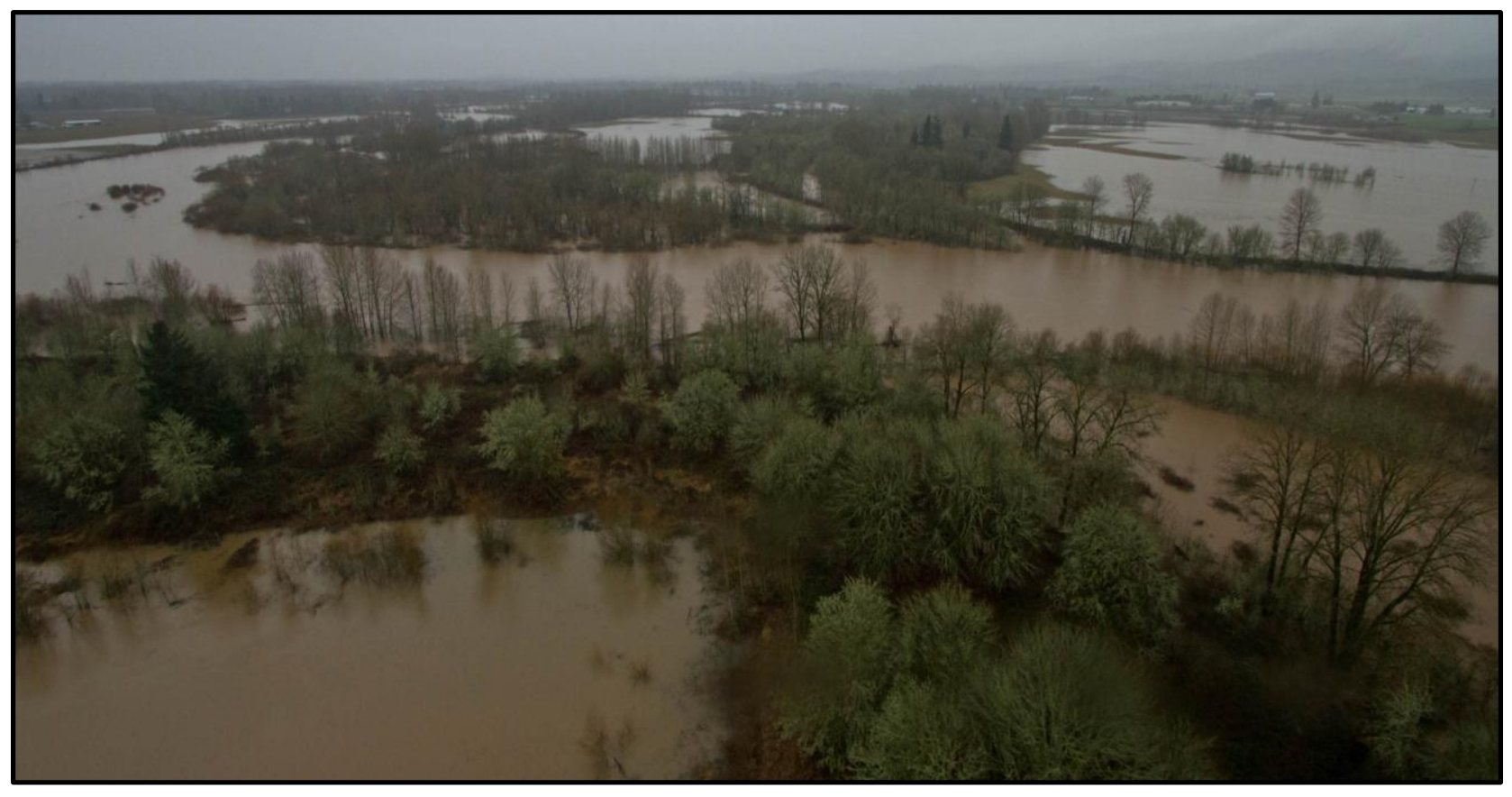

Middle segment of the Willamette River between Corvallis and Albany at high flow, January 2012. Photograph courtesy of Freshwaters Illustrated. 
coarse sediment supply and the frequency of small floods (up to bankfull discharge) where stream power is concentrated within the primary channel (Hickin and Nanson, 1984). Avulsions are abrupt shifts in channel location, such as new chute cutoffs along the inside of meander bends or main channels capturing former side channels. Along gravel-bed rivers in the Pacific Northwest, avulsions typically are driven by large floods and channel-spanning blockages of large wood and gravel, which divert erosive flows toward overbank areas (O'Connor and others, 2003). Examples of recent meander migration and avulsions along the upper Willamette River and North Santiam River are shown in figures 11 and 12.

Rates of channel migration are affected by the nature of the bank materials. Along the Willamette River, indurated Pleistocene gravels (unit $\mathrm{Qg}_{2}$ ) are about 2-5 times more resistant to erosion than Holocene alluvium, whereas revetments are at least 10 times more resistant to lateral channel erosion than Pleistocene gravels (Wallick and others, 2006).
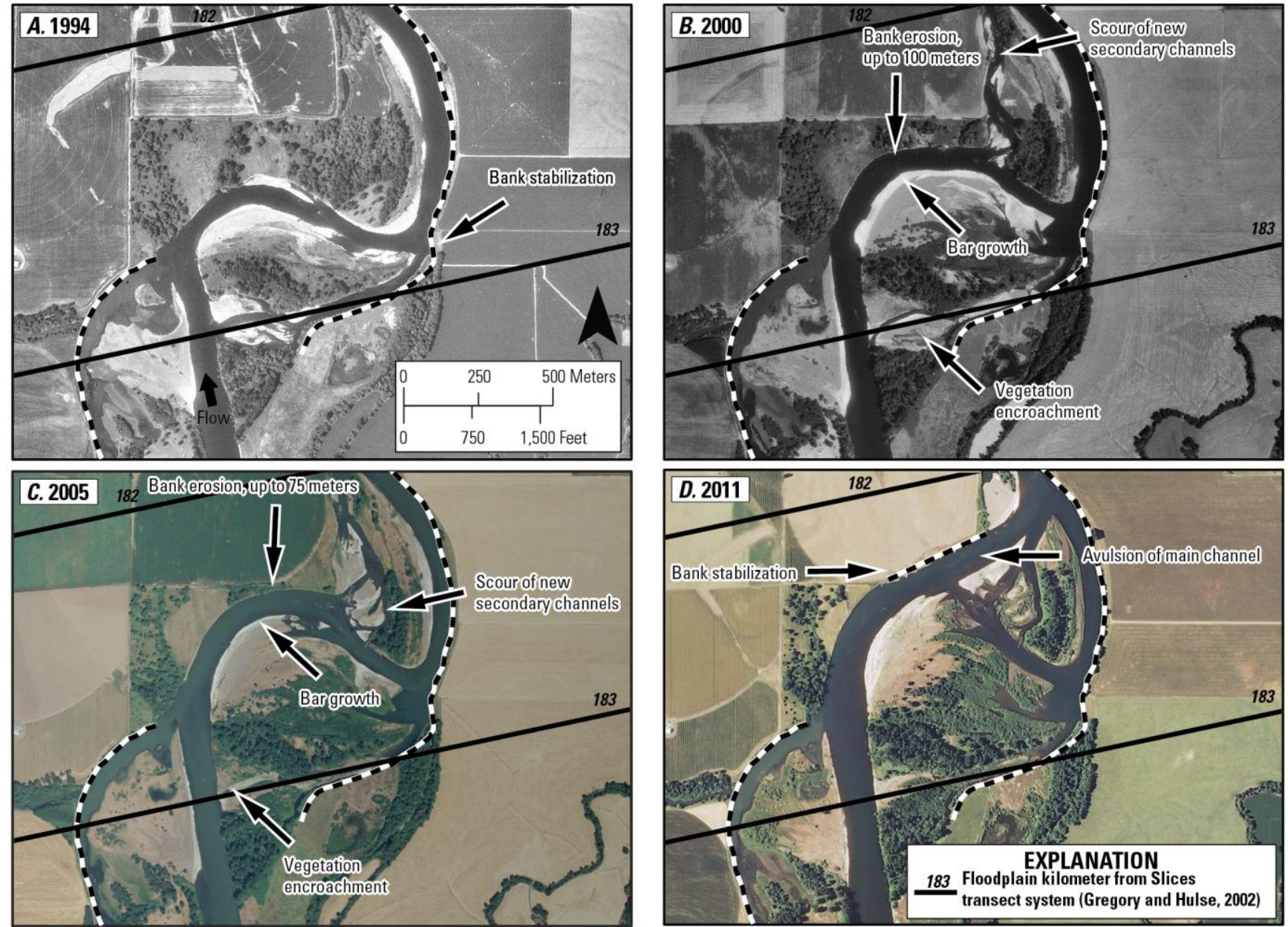

Base maps modified from U.S. Geological Survey and U.S. Department of Agriculture digital data, 1-meter resolution. UTM Zone 10N, NAD 1983

Figure 11. Examples of meander migration and avulsion on upper Willamette River near floodplain kilometer 183, Peoria, Oregon, 1994-2011. A. 1994. B. 2000. C. 2005. D. 2011. 

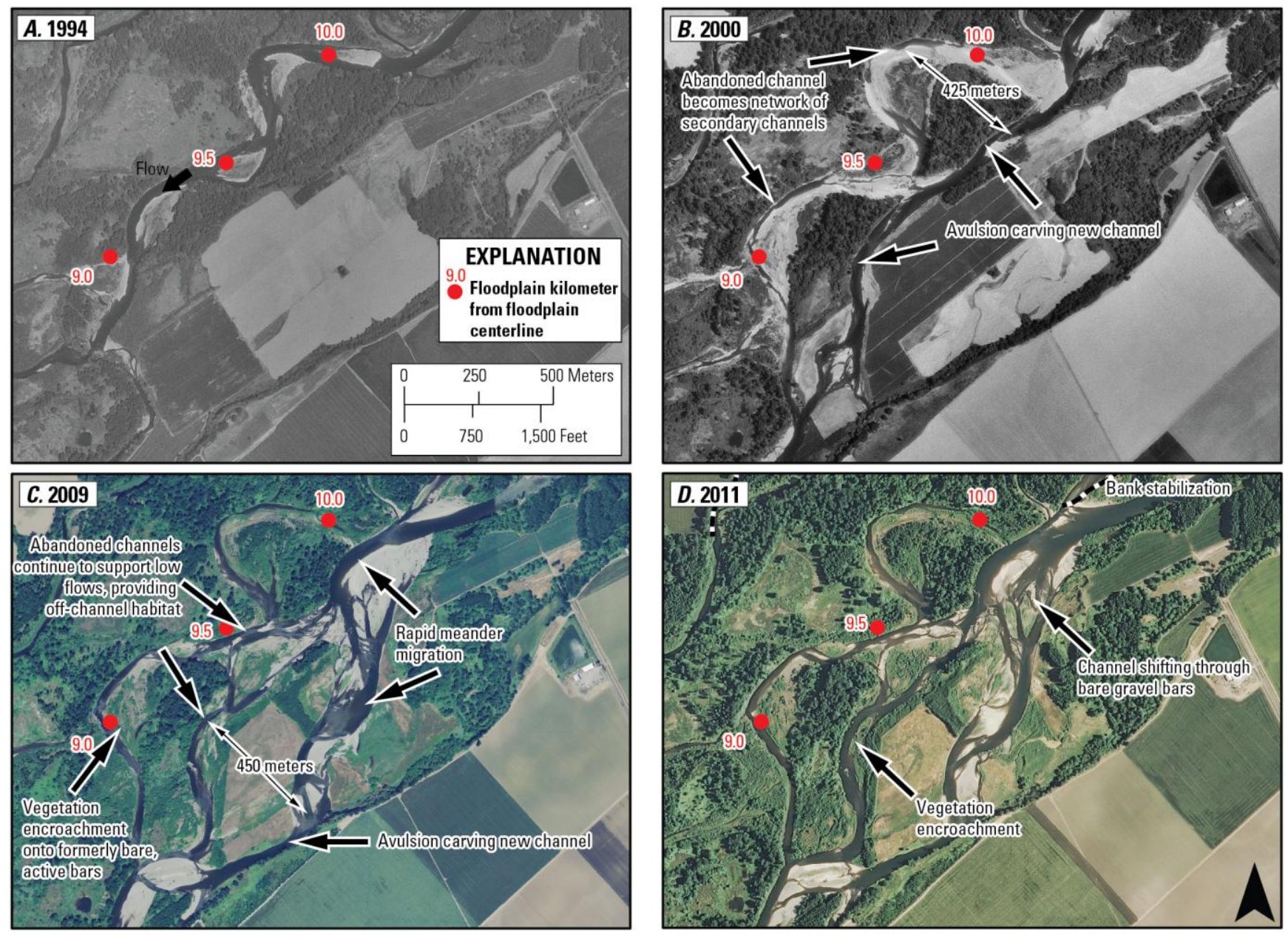

Base maps modified from U.S. Geological Survey and U.S. Department of Agriculture digital data, 0.5- to 1-meter resolution. UTM Zone 10N, NAD 1983

Figure 12. Examples of meander migration and avulsions on North Santiam River near floodplain kilometer 9 , Marion, Oregon, 1994-2011. A. 1994. B. 2000. C. 2009. D. 2011.

Changes in channel depth are another common response of alluvial channels to changes in streamflow and bed-material sediment. When transport capacity exceeds bed-material supply, an alluvial channel may incise, lowering its elevation relative to the flanking floodplain. Conversely, when transport capacity is exceeded by bed-material supply, an alluvial channel will aggrade, increasing its bed elevation. Incision and aggradation can result from individual floods, or can be the persistent response to basin-wide changes in streamflow and sediment inputs. Incision and aggradation also can vary spatially along the length of a river as a consequence of local factors such as bedrock outcrops, resistant
Pleistocene gravels, and revetments as well as sediment inputs from tributaries, bank erosion, and avulsions.

Because incision and aggradation reflect the balance between bed-material supply and transport capacity, adjustments in channel depth often are accompanied by channel width changes. Aggrading reaches are prone to channel widening because deposition of mid-channel gravel bars can trigger bank erosion. In contrast, incising reaches where peak flows are concentrated into a deeper channel may be prone to channel narrowing. 


\section{Vegetation Reponses to Flooding and Sediment} Transport

Composition and succession of riparian vegetation reflect the disturbance history and present-day conditions at a site. The current understanding (and some key uncertainties) of vegetation succession along the Willamette River (a change in species across time in response to site conditions and disturbance history) is shown in figure 13. After a high-flow, a recently deposited or reactivated gravel bar will generally lack vegetation. The moist sediment and open canopy of these bars are ideal for stand initiation by shade- intolerant pioneer species like black cottonwood, willow, and white alder. Seed release and germination of these plants are particularly tied to streamflow. For instance, seed release and germination coincide with the falling limb of the unregulated hydrograph for black cottonwood and willow and when moist and unvegetated gravel bars historically were exposed (fig. 14; Gregory and others, 2007). If a gravel bar remains relatively stable and accretes fine sediment, then it can support vegetation succession, which leads to bar stabilization, more fine sediment accretion, and possibly the merging of the vegetated bar with adjacent floodplain surfaces.

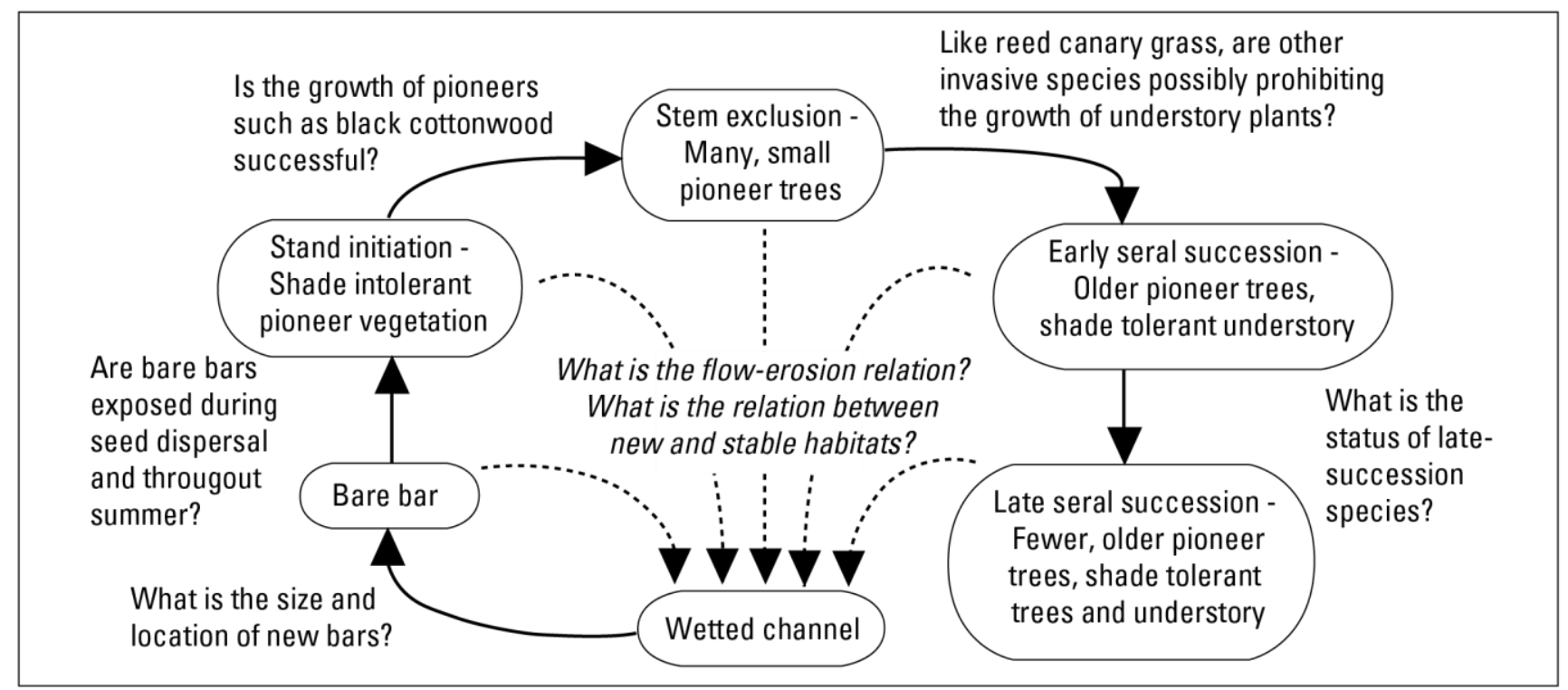

Figure 13. Conceptual model of native vegetation succession for Willamette River, Oregon, floodplains, developed from Fierke and Kauffman $(2005,2006 a, 2006 \mathrm{~b})$ and Naiman and others (2010). About 5-10 years after stand initiation, vegetation enters a stem exclusion phase where many small pioneer trees dominate a landform and their canopies limit understory growth. About 12-15 years after stand initiation, stands enter the early seral succession stage and thin as some willows and black cottonwood die, leaving few older pioneer trees. Tree canopy gaps during this stage permit the growth of understory vegetation, including Indian plum, Oregon ash, and bigleaf maple. As landforms and stands age, black cottonwood gives way to late-succession trees such as bigleaf maple and Oregon ash. In the succession cycle, species diversity and richness tend to be greatest at stand initiation sites. The pool of species during all successional stages, however, may include introduced species, such as reed canary grass, Himalayan (or Armenian) blackberry, and climbing nightshade. 


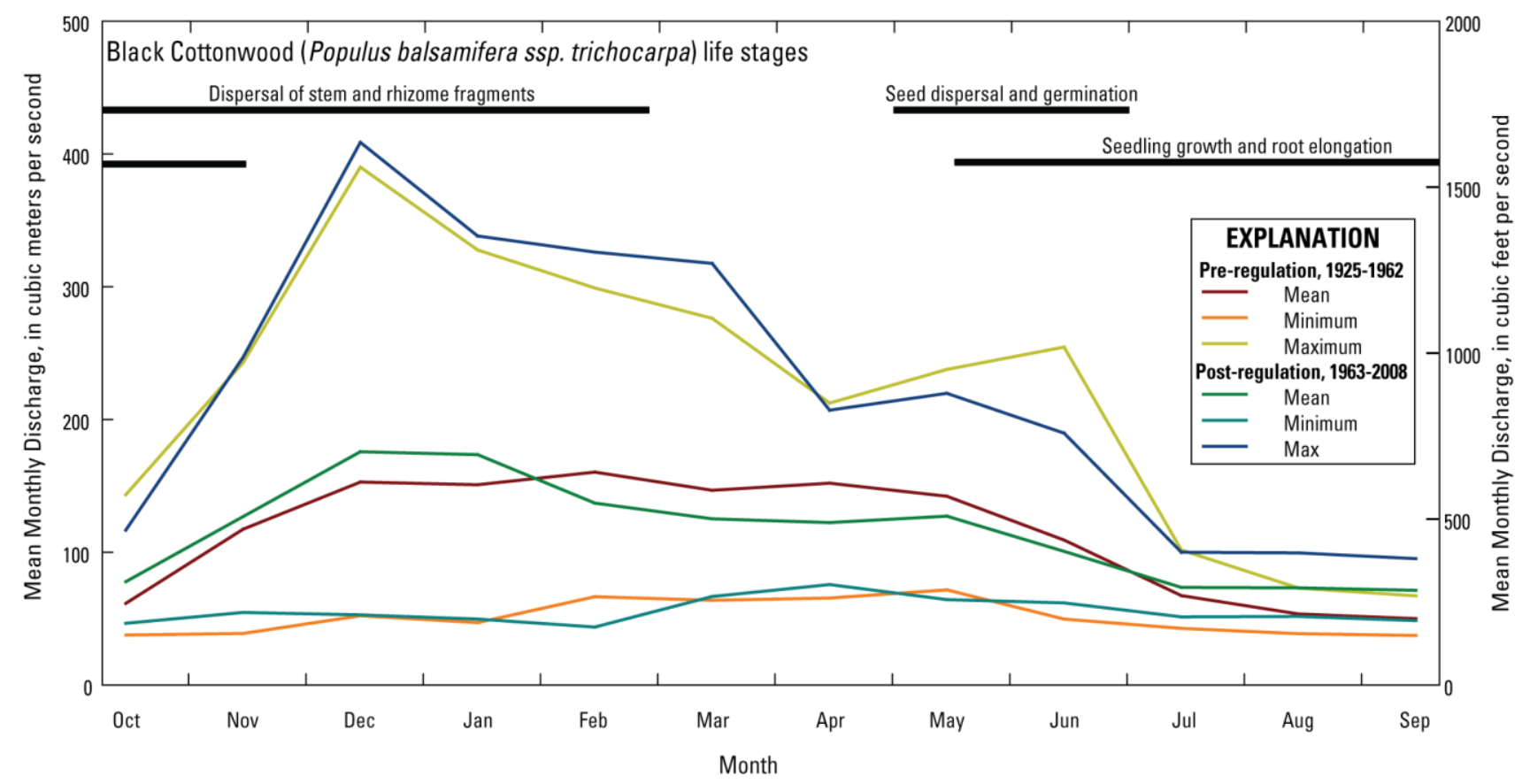

Figure 14. Graph showing example of natural and regulated mean monthly flows for the McKenzie River at Vida, Oregon, and implications for stand initiation. Modified after Gregory and others (2007) and Risley and others (2010).

Throughout succession, vegetation responds to interactions between streamflow and sediment deposition and erosion (fig. 15). These interactions may support stand initiation when gravel bars expand over time because of lateral meander migration (fig. 15A). Interactions between streamflow and sediment deposition and erosion also may reset succession when bars are scoured or reshaped by floods (fig. 15B) or when new surfaces are created by sediment deposition or channel avulsion (fig. $15 B-C$ ). In areas where channels migrate laterally, cyclic sediment deposition and successful stand initiation create patches of similarly aged cottonwoods (Everitt, 1968; Noble 1979). Bands of young, similarly aged woody vegetation are evident along the upper Willamette River in aerial photographs from 1939 (for example, near FPKMs 207 and 205 on the upper segment of the Willamette River; fig. $16 A$ ). Channels abandoned by avulsion, such as those on the upper Willamette and North Santiam Rivers (figs. 11 and 12), typically have moist sediment and open canopies. These abandoned channels potentially provide spatially large, but temporally infrequent, opportunities for pioneer stand initiation (Stella and others, 2011). In basins where flows are comparable to historical flows and channels can migrate freely, erosion and scour of bar and floodplain surfaces can liberate sediment, organic matter, and large wood at any point in the succession cycle. These materials are then transported downstream, where they can help create new bars, riffles, pools, and floodplain surfaces and enter the food web. 

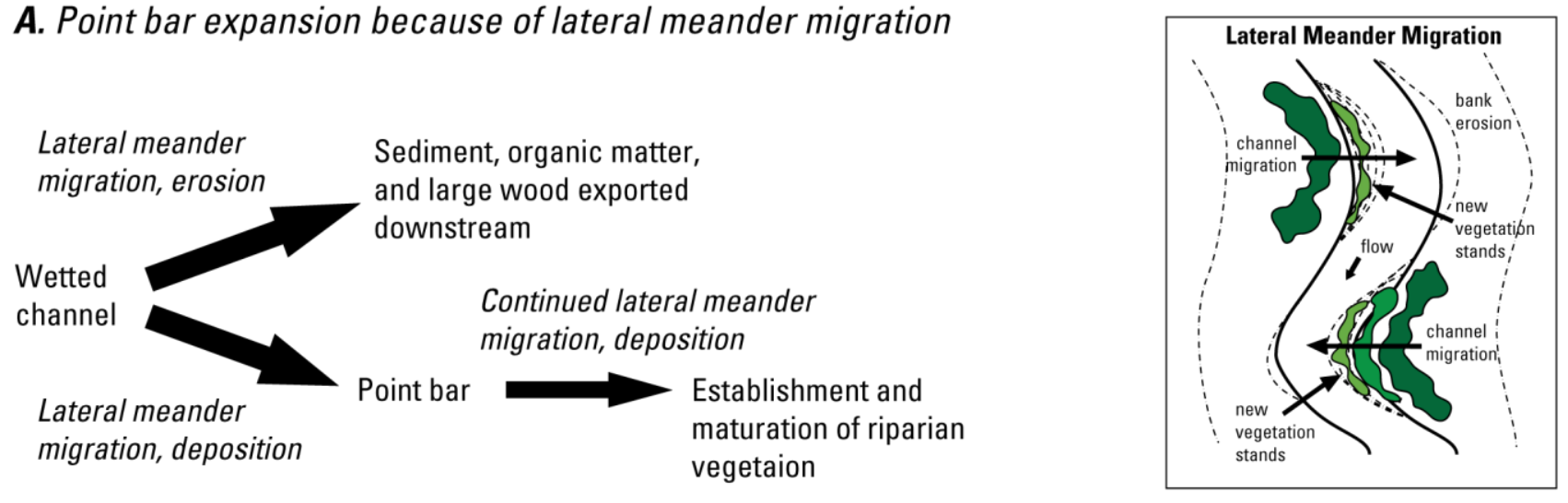

\section{B. Bar resetting because of high flows}
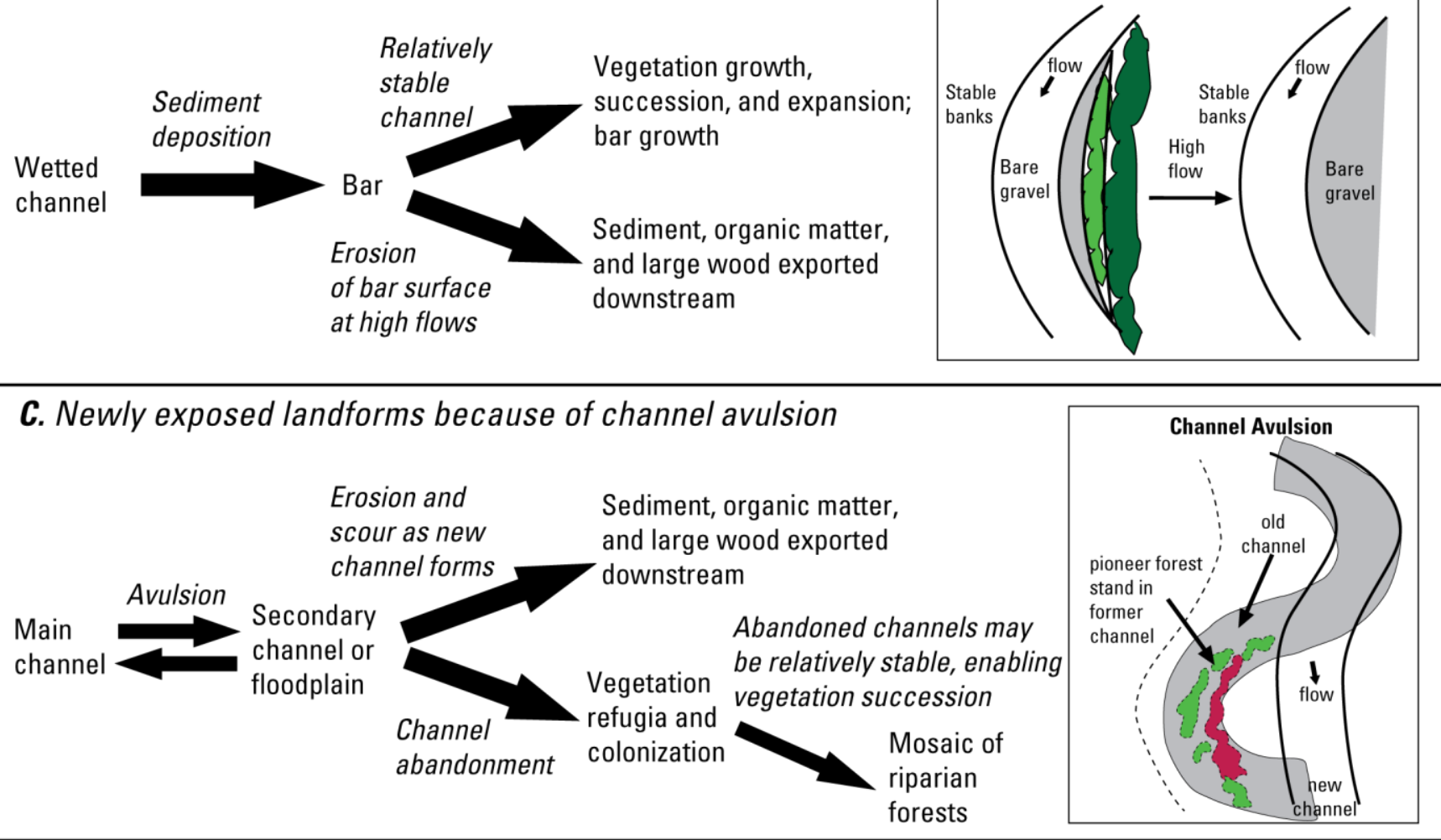

Figure 15. Diagrams showing relationships between channel change and vegetation succession. $A$. Point bar expansion because of lateral meander migration. $B$. Bar resetting because of high flows. $C$. Newly exposed landforms because of channel avulsion. Insets $A$ and $C$ modified from Stella and others (2011). 


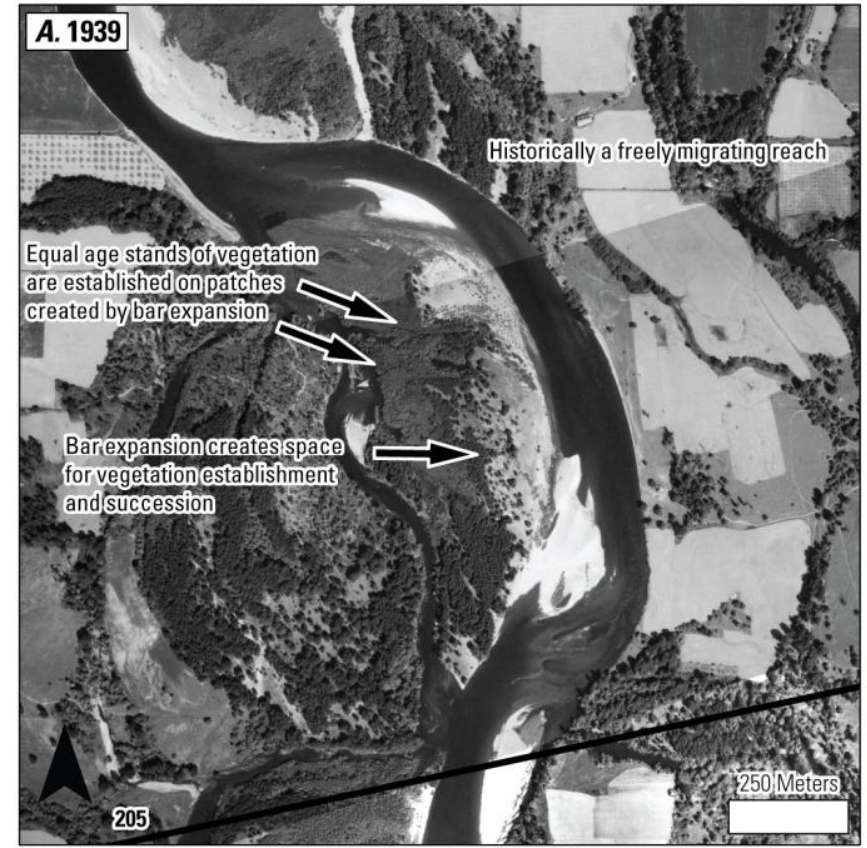

Base maps modified from U.S. Army Corps of Engineers and U.S. Department of Agriculture digital data, various resolutions. UTM, Zone 10N, NAD 1983

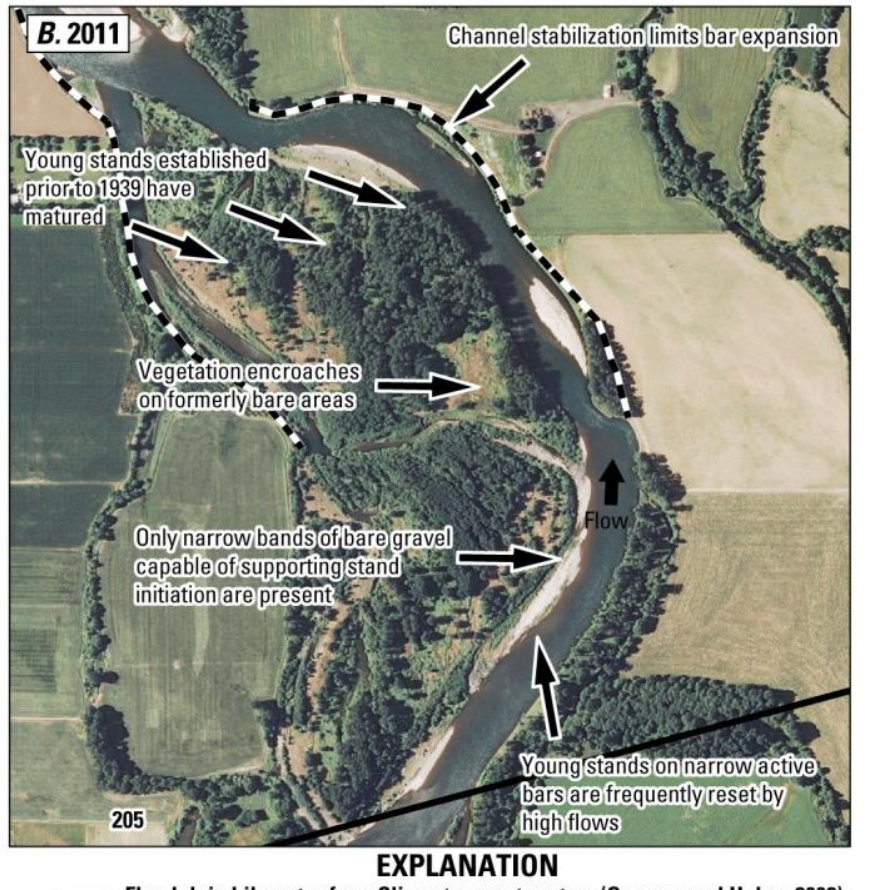

_ Floodplain kilometer from Slices transect system (Gregory and Hulse, 2002)

Figure 16. Historical changes to riparian forests along the upper segment of Willamette River near floodplain kilometer 205, Junction City, Oregon, 1939-2011. A. In 1939, unrestricted meander migration supported immature stands of even-aged vegetation on higher bar surfaces. B. By 2011, young stands of vegetation present in 1939 photographs had matured while channel stabilization limited bar growth and recruitment of new vegetation patches.

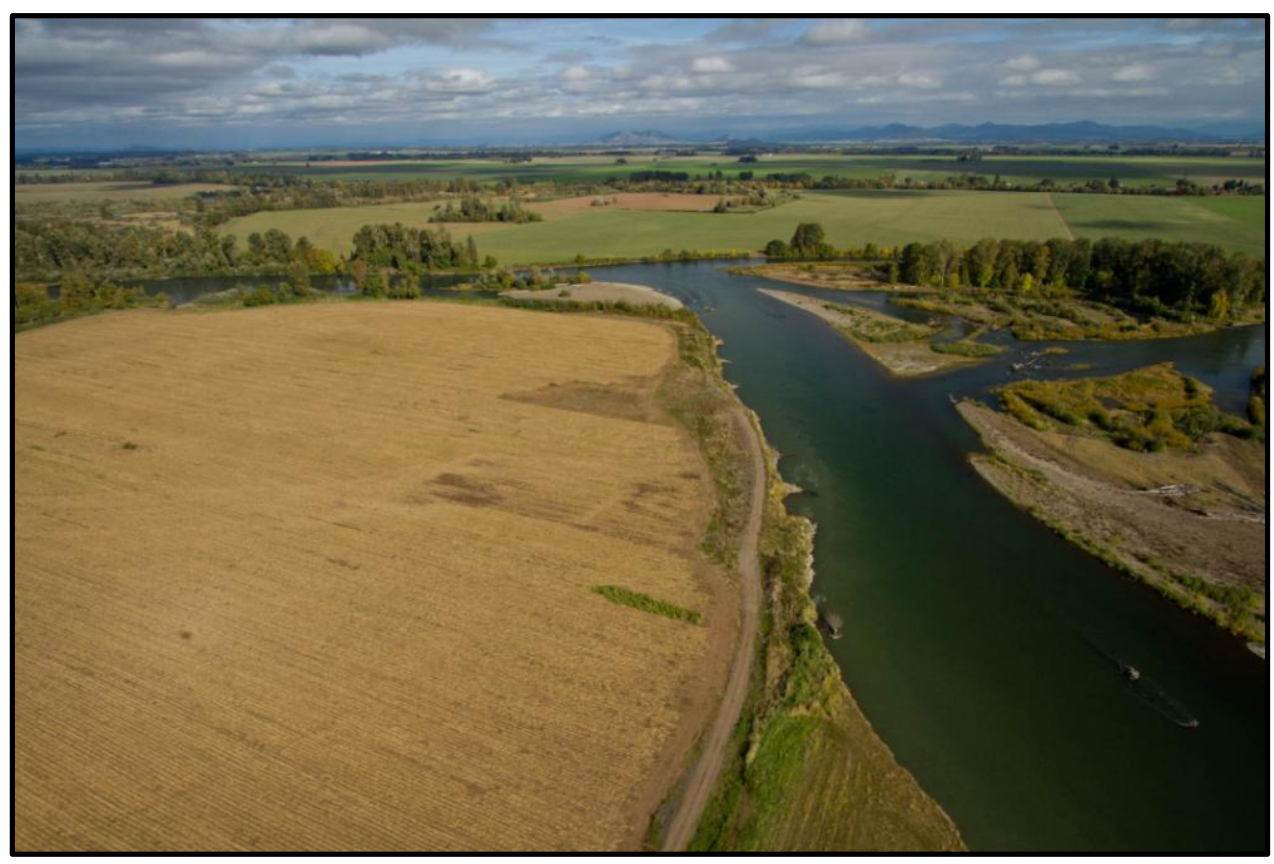

Upper segment of the Willamette River near Monroe, October 2011. Photograph courtesy of Freshwaters Illustrated. 


\section{Transformation of the Willamette Geomorphic Floodplain}

The rivers and floodplains in the Willamette River Basin have changed fundamentally since Euro-Americans first settled in the Willamette Valley in the mid-19th century (fig. 17).

Knowledge of these changes provides a basis for establishing linkages between key processes and geomorphic and ecologic effects. Moreover, historical changes have led to the present condition, which frames possible future geomorphic and ecological trajectories.

\section{Key Alterations to the Geomorphology of the Willamette River Basin}

Historically, the Willamette River was flanked by a broad, forested floodplain and had a complex assemblage of habitats and landforms that were created and maintained by the interactions between large floods, easily erodible bank materials, and substantial inputs of large wood and coarse sediment (Sedell and Frogatt, 1984;
Benner and Sedell 1997; Gregory and others, 2002b; Wallick and others, 2007; Gregory, 2008). Particularly along the upper Willamette River between Eugene and Harrisburg, streamflow was divided among multiple channels commonly separated by large, forested islands and shifting gravel bars.

During the past 150 years, flood control, bank stabilization, large-wood removal, conversion of riparian forests to agriculture, and other large-scale alterations have substantially changed the basin's flow, sediment, and large-wood regimes. These changes are reflected in a narrower floodplain corridor and a less complex assemblage of landforms in the present-day floodplain (fig. 17). In this section we highlight some of the broadscale geomorphic modifications in the Willamette basin and some consequences for landforms, habitats, and vegetation relevant to ongoing management, restoration, and conservation.

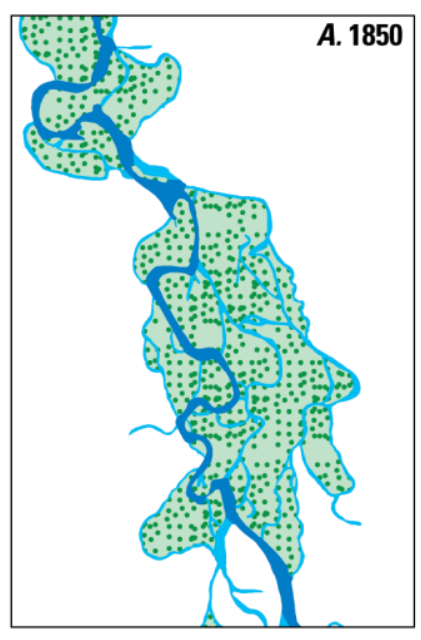

EXPLANATION Active channel feature Primary channel

Secondary water feature

: Island

_ Floodplain kilometer from Slices

transect system (Gregory and Hulse, 2002)

.... U.S. Army Corps of Engineers revetments
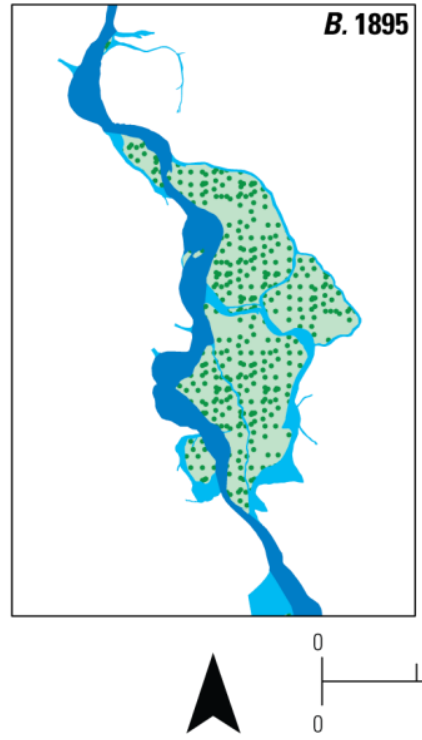

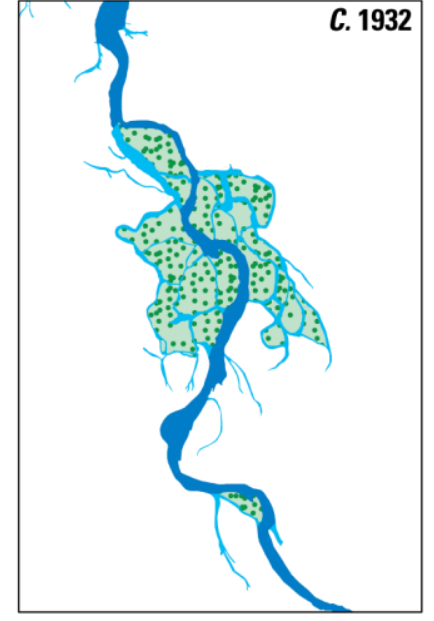

3 Kilometers

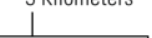

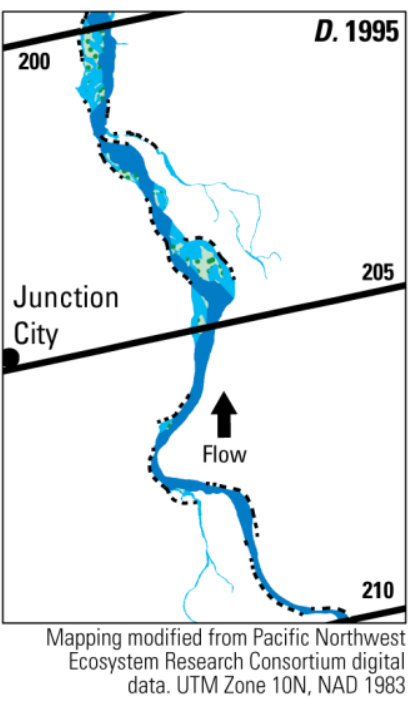

Figure 17. Maps showing historical channel change in the upper valley segment of Willamette River near floodplain kilometers 200-210, Junction City, Oregon, 1850-1995. A. 1850. B. 1895. C. 1932. D. 1995. 


\section{Reductions in Floods and Bed-Material Sediment by Dams}

Flood-control operations in the Willamette River Basin generally aim to confine peak flows to the bankfull channel. As a result, large floods (recurrence interval greater than 10 years before the fully operational USACE Willamette Valley Project) nearly have been eliminated. Also, the magnitude and frequency of small floods (recurrence intervals of 2-10 years before the fully operational USACE Willamette Valley Project) have been reduced substantially (fig. 18; Risley and others, 2010, 2012; Gregory and others, 2007). High-flows up to bankfull discharge still occur frequently, but extend later into the spring and have longer durations than pre-dam condi- tions. For the study area, bankfull discharge is defined by the National Weather Service based on flood hazard, and is slightly smaller than the 1.5 year unregulated discharge (Risley and others, 2010; 2012). Although all valley segments in the study area have had flood peaks reduced, the magnitude of reduction varies between basins and longitudinally with tributary inputs. For example, flood reduction on the Middle Fork Willamette River is more pronounced than on the lower sections of the North Santiam and McKenzie Rivers, which receive comparatively more flow from unregulated Western Cascades tributaries.

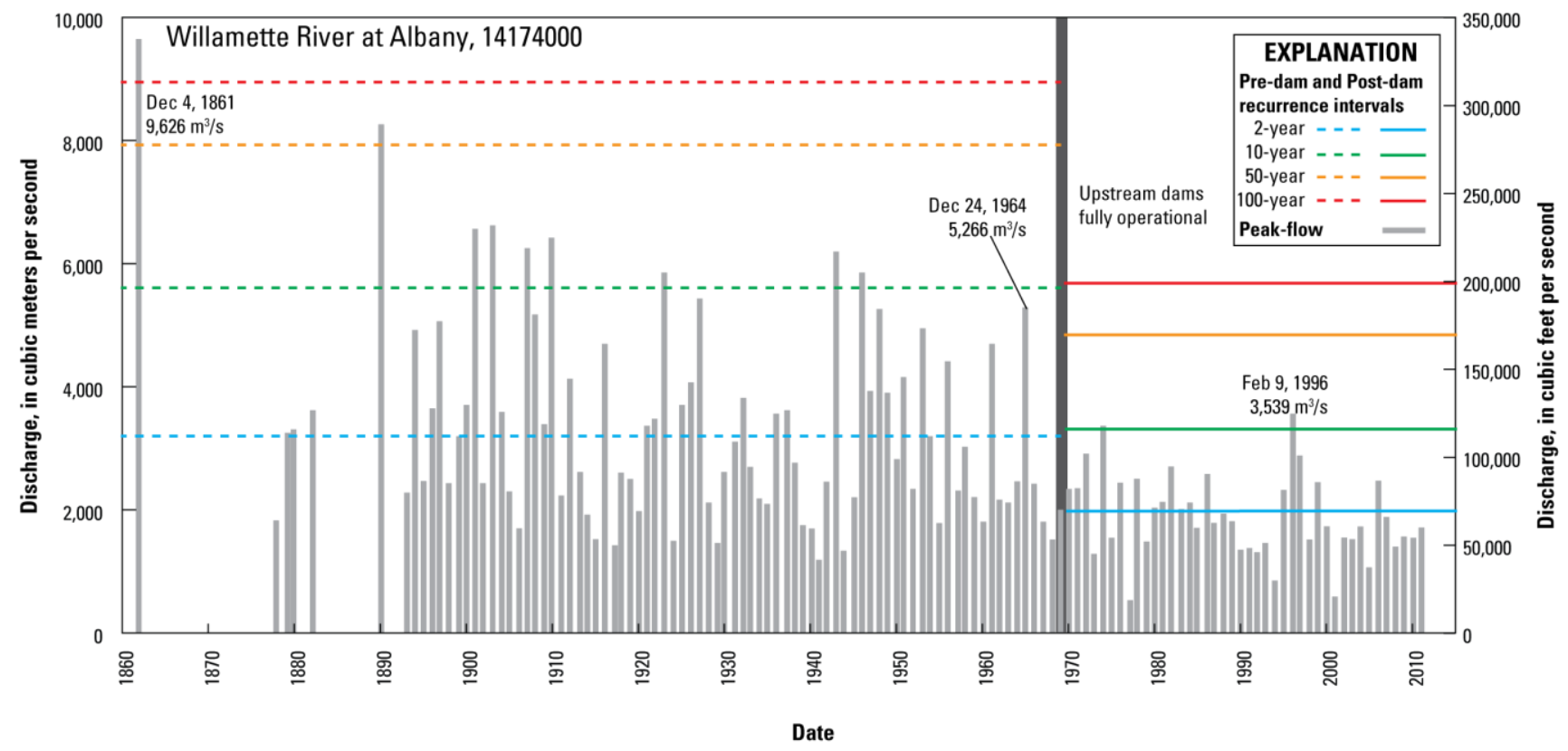

Figure 18. Graph showing peak annual discharge for U.S. Geological Survey streamflow-gaging station Willamette River at Albany, Oregon, (14174000), 1861-2012. Recurrence interval data from Gregory and others (2007). 
Reductions in flood magnitude affect patterns of floodplain inundation and hydraulics within the active channel. The elimination of large-magnitude floods has caused many areas of the historical floodplain to no longer be influenced by occasional inundation and sedimentation, and has reduced geomorphic processes like meander migration and avulsion. Although areas of the floodplain still experience occasional inundation during the present-day 2-year recurrence-interval flow (River Design Group, Inc., 2012a, 2012b), two-dimensional hydraulic modeling on the upper Willamette River shows that stream power resulting from these small floods is mostly concentrated in the active channel (Wallick and others, 2007). This contrasts with the historical regime of large floods occasionally inundating overbank areas with great depths and velocities, leading to floodplain scouring and the creation and renewal of secondary channels (Wallick and others, 2007).

In addition to changing inundation patterns, the reduced peak flows resulting from dams also diminish downstream sediment transport capacity. These decreases can be particularly significant in alluvial rivers like the Willamette River and its major tributaries because most bedload transport is during the few days of the year of highest flows (Klingeman, 1987). For example, flow regulation on the South Santiam River has reduced annual bedload transport capacity by about 80 percent (Fletcher and Davidson, 1988).

Flood-control dams also are physical barriers, trapping bed-material sediment, which would otherwise be transported downstream. Preliminary estimates are that dams trap more than 80 percent of bed-material sediment that historically entered the lower, alluvial segments of the Middle and Coast Fork Willamette Rivers and the South Santiam River (fig. 19). The lower sections of the McKenzie and North Santiam Rivers likely are less affected because they receive coarse sediment from unregulated tributaries. Upstream dams may trap about two-thirds of the bed-material sediment that otherwise would have travelled to the Willamette River at Salem prior to dam construction (O'Connor and others, in press).

\section{Bank Stabilization by Revetments}

The USACE, private landowners, and others have built bank stabilization structures to prevent erosion and to stabilize channels. These structures include placed and dumped rock, wood pilings, asphalt, and concrete. In 1932, nearly 80 percent of the Willamette River between Harrisburg and its confluence with the McKenzie River (FPKMs 200-215) had banks formed of erodible Holocene alluvium. By 1995, only about 25 percent of this reach was able to migrate freely through Holocene alluvium, whereas about 45 percent was constrained by revetments and the remaining 30 percent abutted naturally erosionresistant Pleistocene gravels (Wallick and others, 2007). Revetments are most extensive on the upper Willamette, South Santiam, and McKenzie Rivers (appendix A). Between Eugene and Portland, 26 percent of banks along the main stem Willamette River have revetments, with most revetments on the outside of meander bends (Gregory, 2008; Gregory and others, 2002c).

Because revetments inhibit lateral erosion, they reduce the supply of bed material entering rivers from previously deposited sand and gravel accumulations within the floodplain. These local sources of bed material may now have heightened but unquantified importance because of the diminished upstream supplies (Klingeman, 1987). 


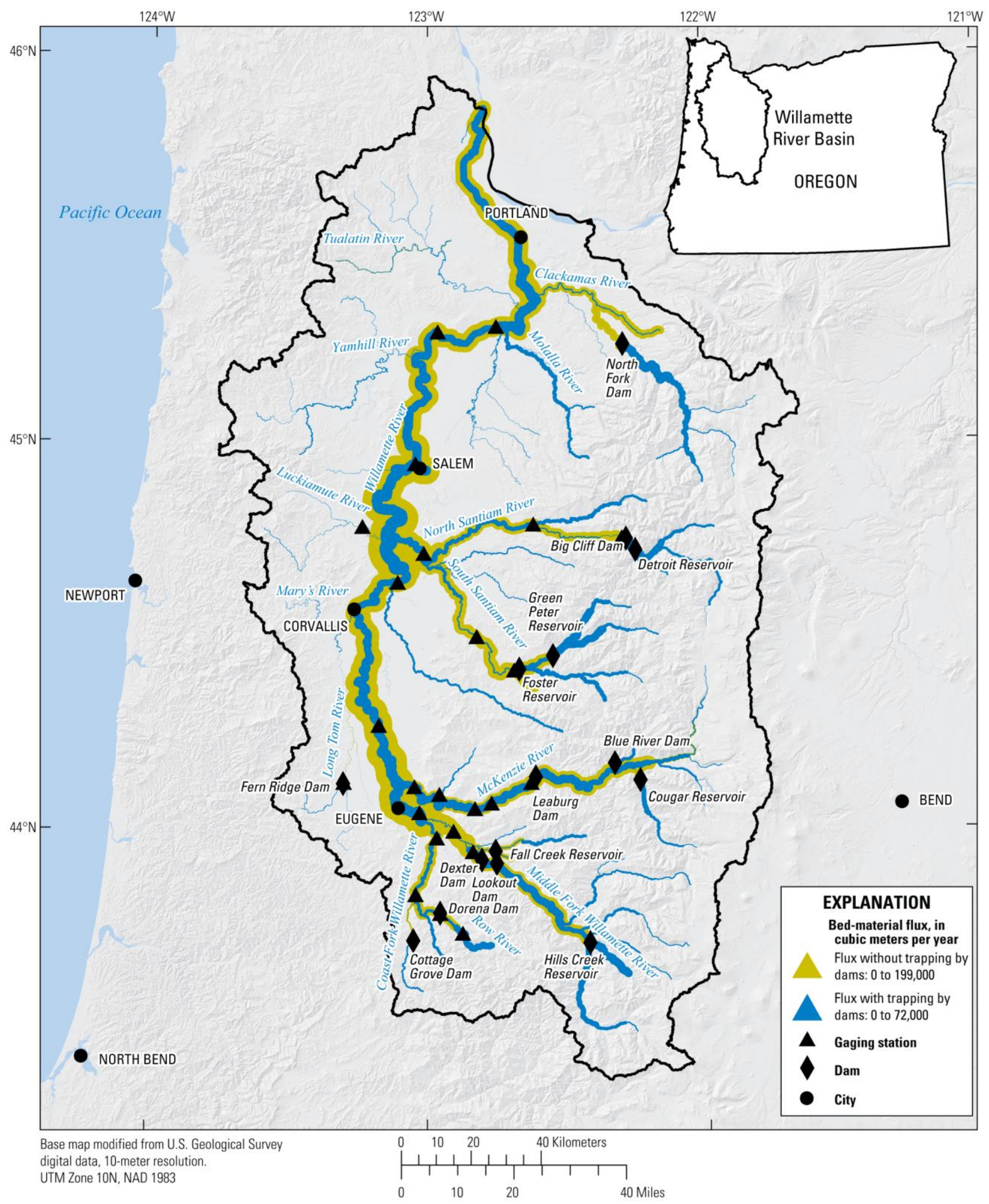

Figure 19. Bed-material flux estimates from O'Connor and others (in press). These estimates account for hillslope bed-material production (on the basis of geology and slope) and downstream fining by attrition, but do not account for sediment supplied or lost to channels from local erosion and deposition. Calculated bed-material flux with dams accounts for coarse sediment trapping by major dams. 


\section{Sediment Removal by Gravel Mining}

Mining of sand and gravel from channels and floodplains also has reduced the volume of bed material in the Willamette River Basin. Peak extraction was during the 1950s through the 1970s (Klingeman, 1973; Achterman and others, 2005). Possible effects of in-stream gravel mining include lowering of the streambed, changes in cross sections, increased turbidity, armoring of bar surfaces, and decreases in downstream bedmaterial transport rates (Kondolf, 1994).

Today, most gravel is mined from numerous floodplain pits in the geomorphic floodplain of the Willamette River Basin. Achterman and others (2005) reported that there were 69 current gravel mining sites covering 2,410 ha $(5,960$ acres) within the 500-year floodplain of the Willamette River. Active and historical mining typically results in water-filled floodplain depressions or pits, even after reclamation. Floodplain mining also can affect channel condition and bed-material transport. The active channel near floodplain mining sites commonly is channelized, leveed, and armored to prevent avulsions into floodplain excavations, which can result in a pit capture and local channel incision (Kondolf and others, 2002).

\section{Reduced Large Wood Inputs and Transport}

Systemwide changes in large wood inputs and transport have fundamental consequences for channel morphology. Historical changes in the Willamette River helped spur global recognition of the role of wood transport and accumulation in controlling channel patterns for large floodplain rivers (Sedell and Frogatt, 1984). As described by the U.S. Army Corps of Engineers, (1875, p. 766), the rich mosaic of Willamette River landforms in the mid-19th century was created partly by an abundance of large wood within the channel and floodplain:

"Each year new channels opened, old ones closed; new chutes cut, old ones obstructed by masses of drift; sloughs become the main bed, while the latter assume the characteris- tics of the former; extensive rafts are piled up by one freshet only to be displaced by a succeeding one; the formation of islands and bars is in constant progress," (U.S. Army Corps of Engineers, 1875, p. 766)

Large wood, however, was systematically removed from the Willamette River to improve navigation in the mid-19th century (Sedell and Frogatt, 1984; Benner and Seddell, 1997).

Wood recruitment also decreased with forest harvesting along the Willamette River and major tributaries in the 19th and 20th centuries and land conversion for other uses (Gregory and others, 2002a). A narrow corridor of mature forest borders some present-day channels, but this wood probably has little interaction with the channels because of lateral channel stability imposed by bank protection and flow and sediment decreases.

The diminished volume of large wood has promoted conversion of historically multi-thread channel reaches like the upper Willamette River to single-thread channels (fig. 17; Sedell and Frogatt, 1984; Gregory, 2002b; Wallick and others, 2007). Restoring multi-thread channels in the upper Willamette River reach will be challenging without the reintroduction of large wood, an important building block for avulsions and for patchy, spatially diverse floodplain forests.

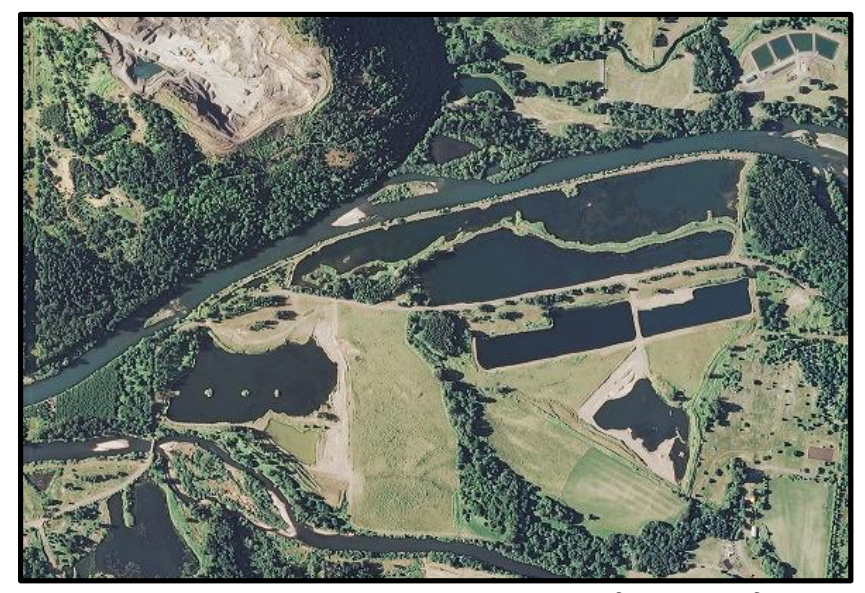

Former gravel extraction site at the confluence of the Coast and Middle Fork Willamette Rivers undergoing aquatic and riparian habitat enhancement by The Nature Conservancy, 2011. NAIP aerial imagery. 


\section{Consequences of Changes in Floods, Sedi- ment Fluxes, and Bank Stability}

Gravel-bed rivers within the Willamette River Basin can, over time, adapt to changes in sediment and wood supply, flow, and bank stability through adjustments in channel geometry and bed texture. Typical responses of gravel-bed rivers to upstream dams and revetments include narrowing and deepening of the channel and coarsening of bed sediment. Long-term consequences of in-stream and floodplain gravel mining are likely similar because they reduce the overall sediment supply in the channel and lead to changes in channel width and depth and, in some cases, increases in channel stability to prevent pit captures. Likewise, reduced wood supply may lessen avulsion and meander migration rates and cause changes in channel depth and width.

The overall magnitude of channel adjustments to changes in flow, sediment, wood, and bank stability will vary longitudinally depending on variation in sediment particle sizes, local hydraulic conditions, tributary inputs of flow and sediment, and the types and distribution of bank materials. Complex interactions among these processes can also influence the magnitude and rate of channel adjustments, For example, bed armoring can inhibit incision (Grant, 2012). Channel adjustments, in turn, have implications for aquatic and riparian ecosystems dependent on a more dynamic river and floodplain system.

\section{Coarsening of the Channel Bed Downstream of Dams}

One implication of reduced bed-material supply is coarsening (or armoring) of the streambed. For instance, most areas immediately downstream of the flood-control dams now have transport capacities far exceeding the supply of bed material, resulting in pronounced bed armoring and skeletal boulder bars devoid of cobble and gravel. Although coarsening and armoring has not been systematically evaluated, these effects may extend far downstream from dams. For example, bed sediment evaluations for the Willamette and McKenzie Rivers indicate bed coarsening on both rivers during the 20th century (Klingeman, 1987; Minear, 1994).

Downstream conditions may be ameliorated by tributary sediment inputs. Additionally, the reduced transport capacity resulting from diminished flood peaks may also create situations of finer-textured beds and more gravel bars, such as locally the case for the McKenzie and Santiam Rivers (Risley and others, 2010, 2012).

A consequence of these longitudinal bedtexture patterns is that the distribution of gravel and locations of salmon-spawning areas generally do not coincide. For example, spawning of spring Chinook Salmon is concentrated directly downstream of the dams on the South Santiam and Middle Fork Willamette Rivers, where suitable gravels for redd building are now sparse (National Marine Fisheries Service, 2008; Greg Taylor, U.S. Army Corps of Engineers, oral commun., September 20, 2012). Likewise, on the McKenzie River, bed coarsening has reduced the availability of suitable spawning habitat (Lignon and others, 1995).

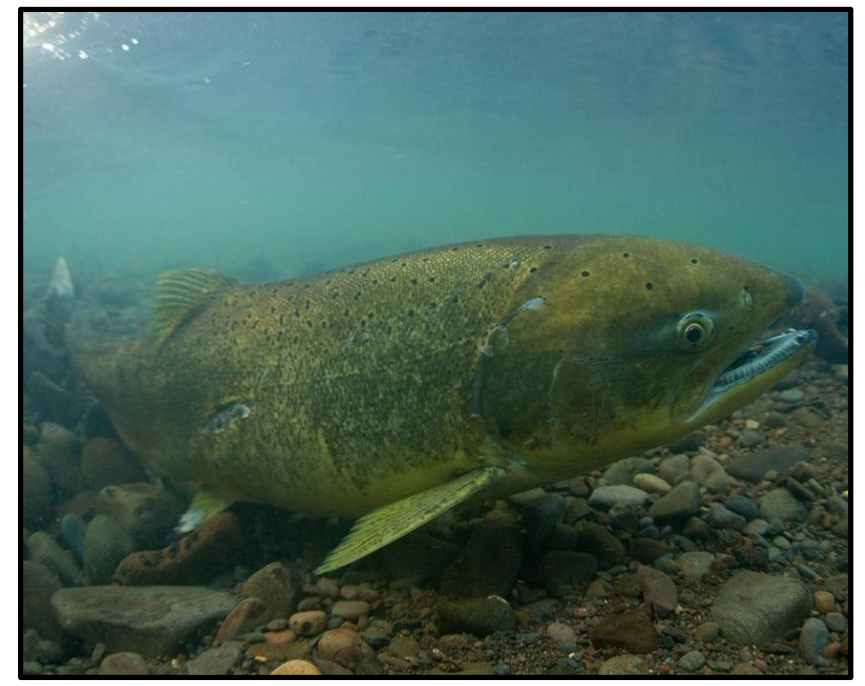

Spring Chinook Salmon over spawning redd, South Santiam River, September 2012. Photograph courtesy of Freshwaters Illustrated. 
Widespread Loss of Side Channels, Islands, and Unvegetated Gravel Bars

In conjunction with reduced sediment and wood inputs, and decreased peak flows, the number of side channels, islands, and gravel bars has declined substantially throughout the study area during the 20th century (figs. 20 and 21). On the Willamette River, the area of islands and river channels decreased by 63 and 22 percent, respectively, between 1850 and 1995 (Gregory and others, 2002a). On the McKenzie River, the area of unvegetated gravel bars decreased 60 percent between 1939 and 2005 (Risley and others, 2010). Similar findings have been reported for the South Santiam River and the Coast and Middle Forks of the Willamette River (Fletcher and Davidson, 1988; Dykaar, 2005).

The diminished area of bare gravel bars on the upper Willamette River and on the Coast and Middle Forks of the Willamette River is largely the result of flood control and bank stabilization decreasing the frequency of gravel entrainment and deposition (figs. 20 and 21D). Consequent vegetation colonization and overbank sedimentation has allowed these former bar surfaces to gradually coalesce with adjacent floodplains (Dykaar and Wigington, 2000; Gutoswky, 2000; Dykaar, 2008a; Gregory, 2008).
Fewer side channels, islands, and unvegetated gravel bars has consequences for aquatic habitats and vegetation. For instance, coldwater refugia have been identified as a limiting factor for migrating salmon in the Willamette River Basin (Hulse and others, 2007; National Marine Fisheries Service, 2008). Coldwater refugia commonly result from hyporheic exchange, where river water flows into shallow, alluvial aquifers (the gravel on and beneath the channel bed) and transfers heat to the surrounding sediment before returning to the river. Depending on the length of time water moves through the subsurface and other factors, returning water can be substantially cooler than ambient water temperatures in summer (Poole and others, 2008). In alluvial rivers, complex channel geometry and a diversity of channel features create high and low elevation points, or hydraulic gradients, which in turn drive hyporheic exchange. One implication of this is that channels with greater geomorphic complexity tend to have greater rates of hyporheic exchange (Poole and others, 2006), whereas stabilized channels tend to have reduced geomorphic diversity and less hyporheic exchange (Fernald and others, 2001; Burkholder and others, 2008), thereby reducing coldwater refugia and thermal buffering (Hulse and others, 2007; Burkholder and others, 2008).

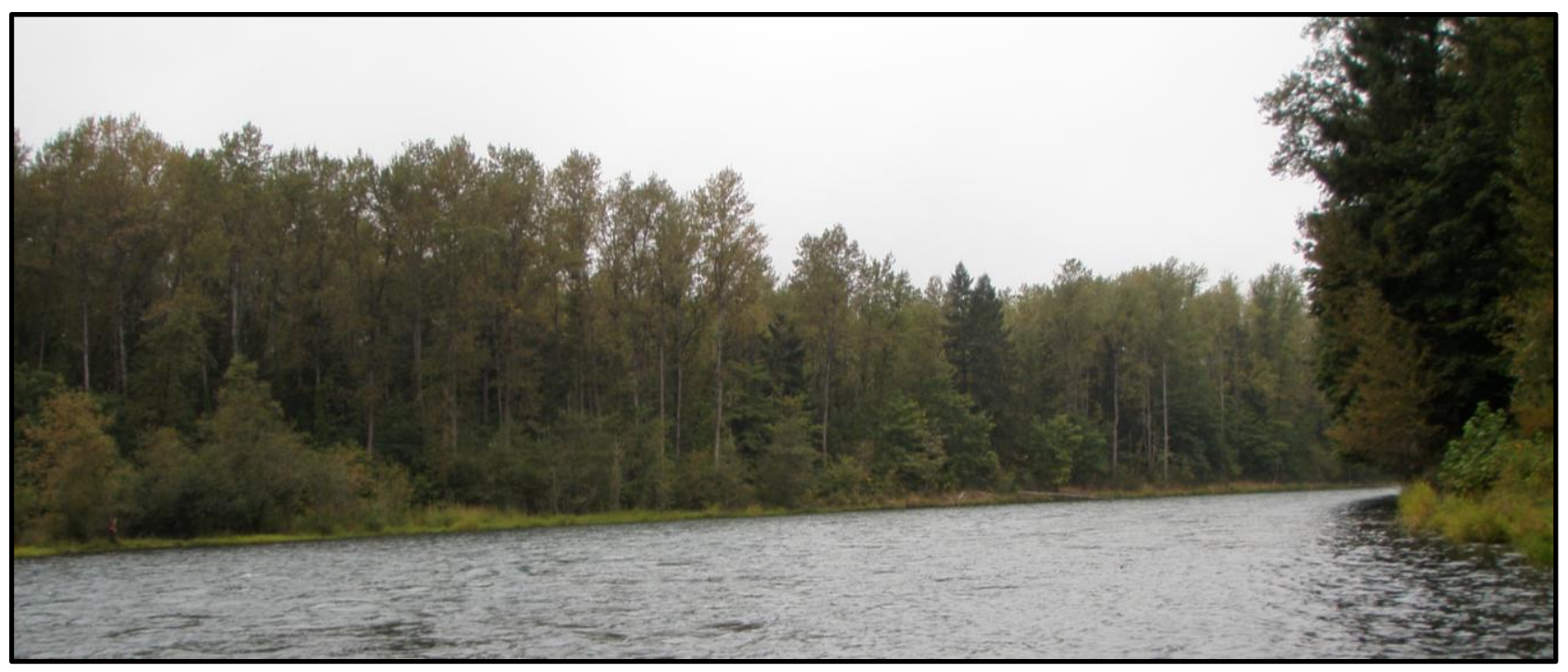

Reach of the Middle Fork Willamette River near Dexter with few bare gravel bars and mature forest, September 2012. 

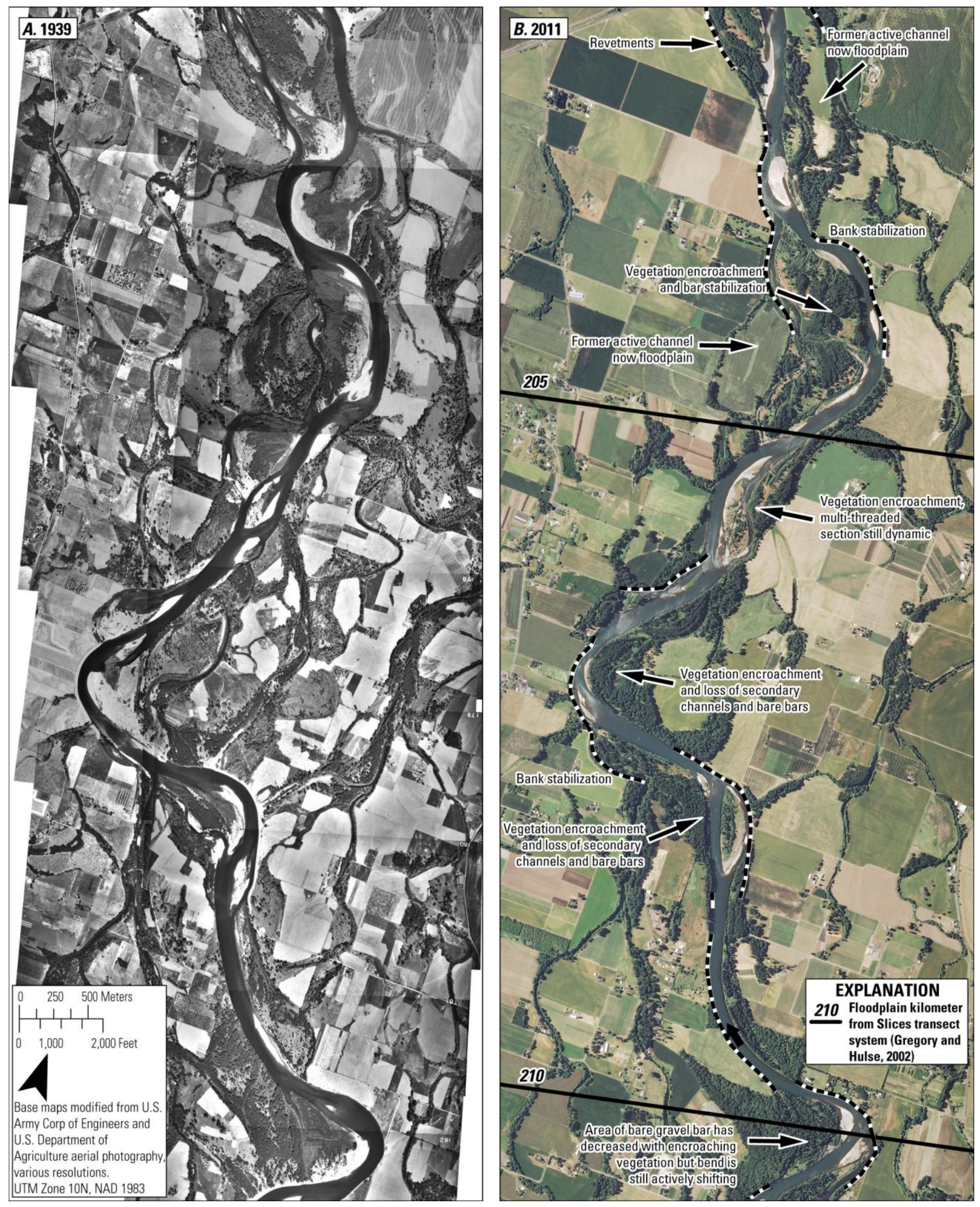

Figure 20. Aerial photographs showing changes in the upper valley segment of the Willamette River near floodplain kilometers 205-210, Junction City, Oregon, 1939-2011. 

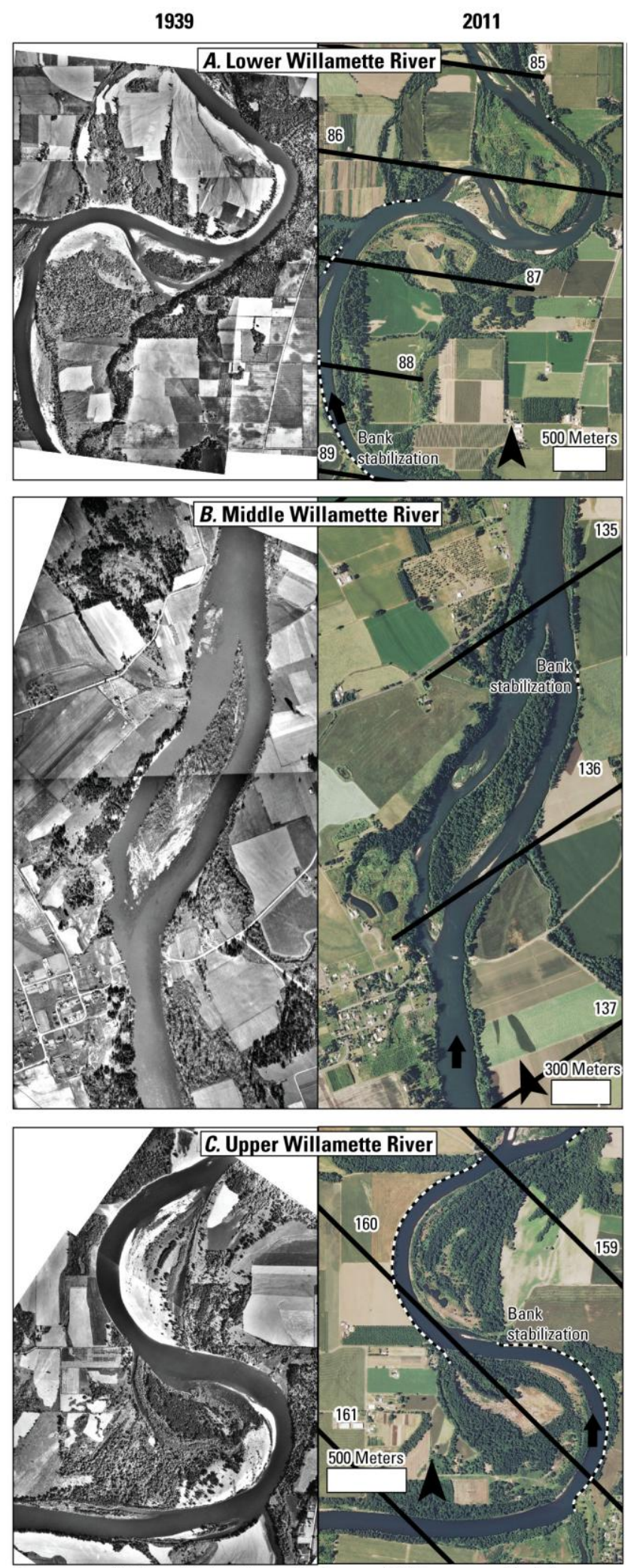

Base maps modified from U.S. Army Corps of Engineers and U.S. Department of Agriculture aerial photography, various resolutions. UTM Zone 10N, NAD 1983

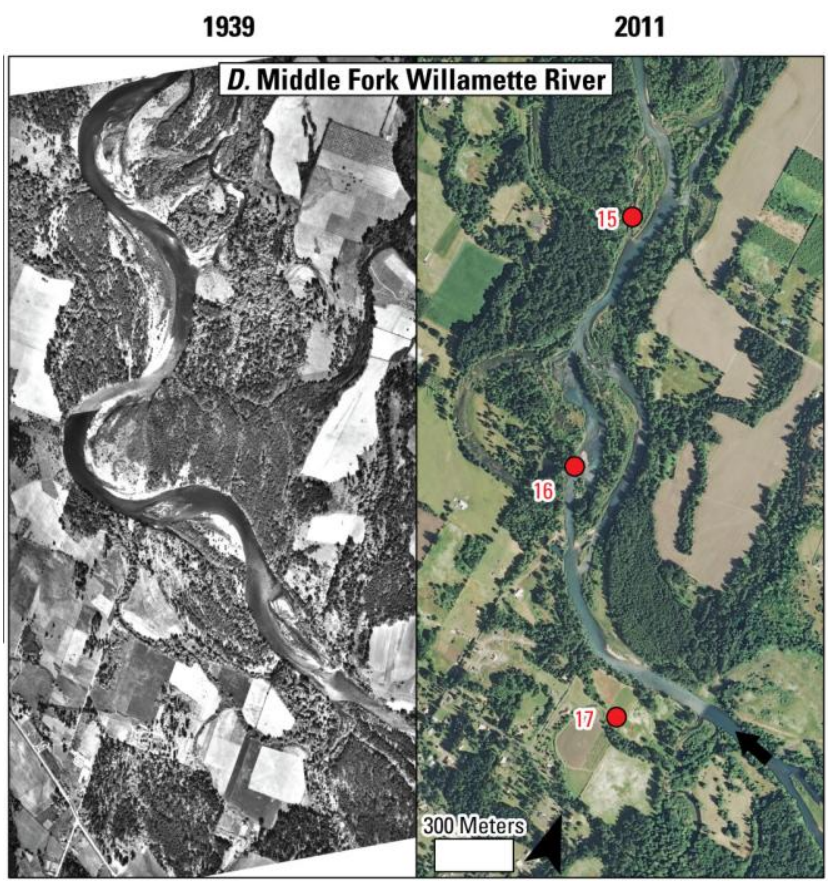

\section{EXPLANATION}

137 Floodplain kilometer from Slices transect system (Gregory and Hulse, 2002) 160 Floodplain kilometer from floodplain centerline

Figure 21. Aerial photographs showing changes in the Willamette River and Middle Fork Willamette River, Oregon, 1939-2011. A. Lower segment of Willamette River near Dayton (floodplain kilometers 85-89). $B$. Lower segment of Willamette River near Buena Vista (floodplain kilometers 135-137). C. Middle segment of Willamette River near Half Moon Bend (floodplain kilometers 159-161). D. Middle Fork Willamette River near confluence with Fall Creek (floodplain kilometers 15-17). 


\section{Channel Width and Depth Changes}

Channel morphology has also evolved as sediment and flow conditions have changed. In many locations the channel has narrowed; as much as 10-20 percent along three Willamette River reaches between Newberg Pool and the McKenzie confluence from 1932 to 1995 (Wallick and others, 2007). Even greater narrowing has been measured for sections of the South Santiam River and Coast and Middle Fork Willamette Rivers (Fletcher and Davidson, 1988; Dykaar, 2005).

Channels have also incised in some locations. On the basis of gaging station measurements from water years 1935-1965, Klingeman (1973) reported 0.3-1 m of incision at USGS gaging stations on the Willamette River, Coast and Middle Fork Willamette Rivers, Santiam River, and McKenzie River, which was attributed to in-stream gravel mining and other factors.

We have updated seven of Klingeman's (1973) gaging station analyses within the basin. For this report, we also analyzed gaging stations on the Coast and Middle Fork Willamette Rivers. Our methods are similar to more recent analyses in other basins in western Oregon (Jones and others, 2012).

These specific-gage analyses evaluate changes in streambed elevation by assessing changes in water elevation (stage) across time for specific discharge values. Our analyses emphasize flow stages associated with low flows (the 95- and 75-percent flow exceedance values depicted by the black and blue lines, respectively, in fig. 22) because they are more sensitive than high flows to changes in bed elevation. The records at all of the Willamette Basin analysis locations are discontinuous because of station moves, datum shifts, and absent records; and results may not be reflective of entire river segments because stream locations are preferentially located in areas of channel stability. Nevertheless, periods of sustained measurements showing persistent trends in channel elevation likely indicate reachscale channel behavior.
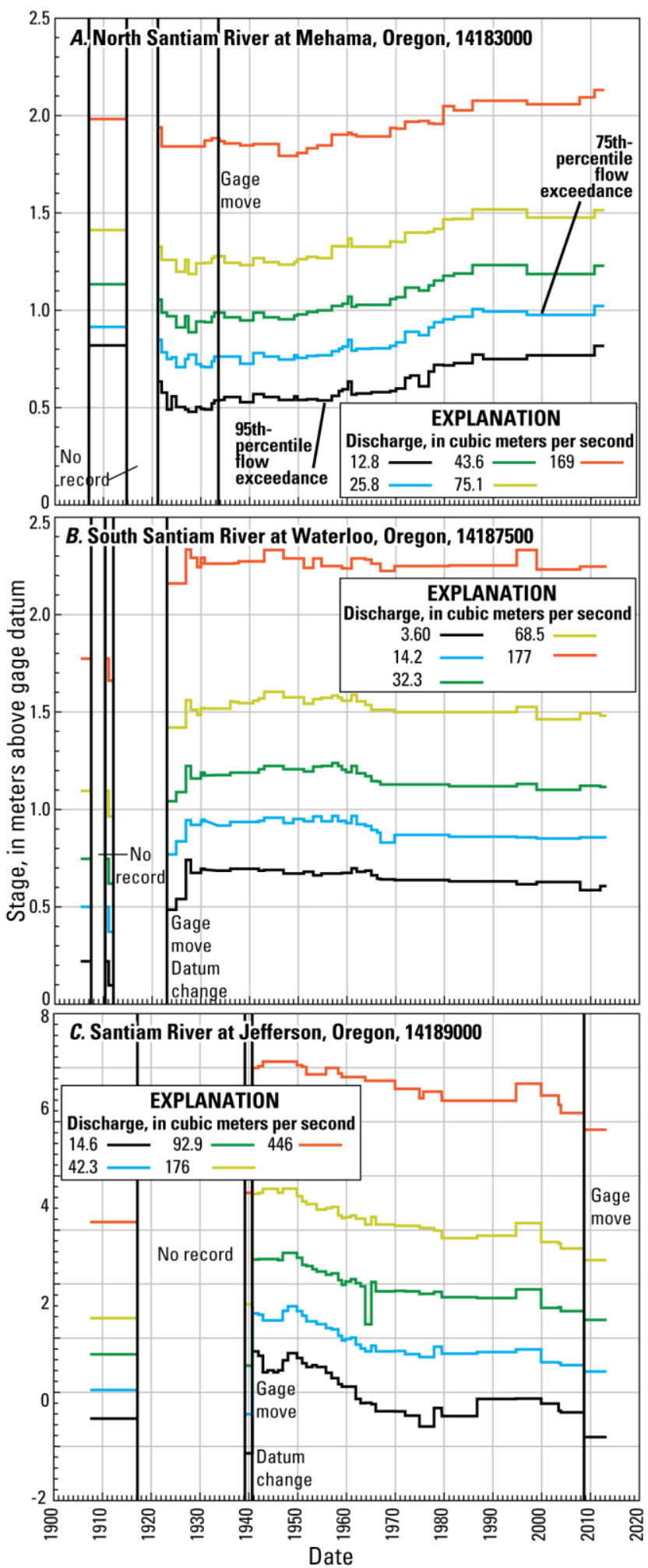

Figure 22. Specific gage analyses for the North, South, and main stem Santiam Rivers, Oregon. 

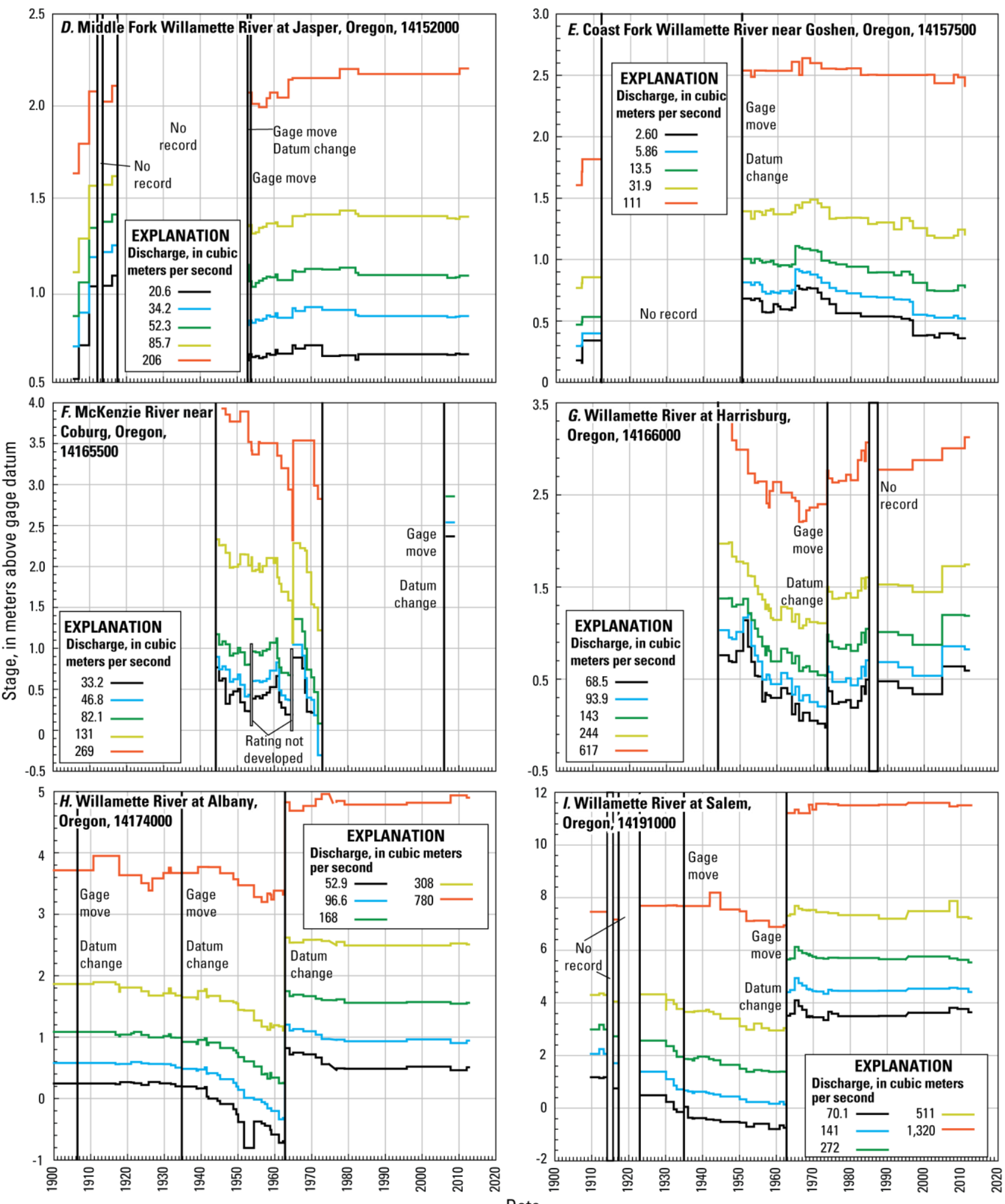

Figure 22-continued. Specific gage analyses for main stem, Coast Fork, and Middle Fork of the Willamette River, and the McKenzie River, Oregon. 
The specific-gage analyses for the seven stations within the study area all indicate channel incision of $0.3-1.3 \mathrm{~m}$ prior to water year 1975 (fig. 22; table 3). Bed-lowering continued through 2012 at three of these seven stations (Santiam River at Jefferson, Coast Fork Willamette River near Goshen, and Willamette River at Salem). Incision prior to 1975 was followed by relative stability through 2012 at two other stations (Middle Fork Willamette River at Jasper and Willamette River at Albany). The Willamette River at Harrisburg incised until 1973, and then aggraded a net $0.3 \mathrm{~m}$ by 2012 . The McKenzie River near Coburg incised through 1972 when measurements ceased. Although this measurement location was discontinued, no recent variations in bed elevation were observed from limited measurements collected from 2007 to 2012 at a new site. The channel aggraded $0.3 \mathrm{~m}$ between 1965 and 2012 at the North Santiam station while the South Santiam station remained largely stable from 1927 to 2012. These stations, however, are upstream of the study area, and probably not representative of conditions along the downstream alluvial segments.

Considered as a group, the updated specific gage analyses for the nine USGS streamflowgaging stations in general indicate that most historical incision was prior to 1965 (fig. 22). Between 1965 and 2012, changes in bed elevations varied substantially among the measurement sites, but incision has slowed or stopped at most measurement sites.

The specific causes for incision are unclear. As Klingeman (1973) noted, 1940s-1960s incision predates full implementation of the Willamette Valley Project and may owe to instream gravel mining. Gradual slowing of incision and more stable channel-bed elevations in recent decades may reflect overall channel stabilization resulting from reduced transport capacity and bed armoring, which has been inferred to limit incision on other regulated gravel-bed rivers (Grant, 2012). Better understanding of the causes of incision and subsequent channel be- havior in the Willamette Basin requires more detailed analyses of individual reaches, including assessment of other sources of channel elevation information and investigation of local causes for changes in bed-material transport rates and changes in channel morphology.

\section{Decreased Channel Mobility}

Rates of meander migration and the frequency of channel avulsions have decreased substantially throughout the study area in the 20th century because of reduced flood peaks, diminished wood and bed-material fluxes, and bank stabilization (Fletcher and Davidson, 1988; Dykaar and Wigington, 2000; Dykaar, 2005, 2008a, 2008b; Wallick and others, 2007). In particular, bank protection structures reduce bank erosion rates and meander migration, especially along extensively revetted river segments, such as the South Santiam, upper Willamette, and McKenzie Rivers.

Bank erosion and lateral meander migration also are reduced by decreased bar growth and increased establishment of vegetation on formerly active bars. Bar growth helps steer high-velocity flows toward opposite channel banks, promoting lateral meander migration. For other western Oregon rivers, active bar area correlates with channel migration rates ( $\mathrm{O}^{\prime}$ Connor and others, in press); consequently, channels lacking numerous bars are likely to be less dynamic and to have more simplified flow patterns. Establishment of vegetation on formerly active gravel-bar surfaces also slows bank erosion by increasing flow resistance and bank cohesion (Thorne, 1990; Thorne and Furbish, 1995; Micheli and Kirchner, 2002; Simon and Collison, 2002).

Avulsions are abrupt channel shifts across the floodplain without substantially eroding or reforming the intervening flood-plain surface. They are now much less common than historically; on the upper Willamette River, the frequency of avulsions in 1972-2000 was 70 percent less than in 1850-1895 (Wallick and others, 2007). Similarly, no avulsions occurred between 1979 
and 2008 along the historically dynamic sections of the lower Coast Fork and Middle Fork Willamette Rivers (Dykaar, 2008a) despite the 1996-97 flood.

Fewer avulsions are the consequence of (1) the present-day absence of large channelblocking wood jams, particularly in the Upper Willamette River, and (2) few large floods with sufficient stream power to carve cut-off channels across overbank areas. Since dam construction, the largest floods, such as those in 1996-1997, may inundate floodplain areas, but they only have the stream power to trigger avulsions at low elevation, former channels or easily erodible, sparsely vegetated gravel bars (fig. $11 D$; Wallick and others, 2007). Other factors limiting avulsions are revetments blocking connections with former side channels and incision limiting the ability of small floods to inundate overbank areas and scour cut-off channels.

Avulsions are associated with several key habitat formation processes. Erosion of a new floodplain channel introduces sediment and wood into the channel, where they may promote downstream channel dynamics, including bar building, bank erosion, and lateral channel migration (O'Connor and others, 2003; Collins and others, 2012). Additionally, introduced wood and sediment provides in-channel cover and diverse substrates. Channel shifting associated with avulsions also results in a variety of floodplain features, such as floodplain lakes (including oxbows), secondary channels, and alcoves. Although to our knowledge no comprehensive studies have examined the relation between avulsion frequency and these habitats in the Willamette River floodplain, it is likely that decreased avulsion (and overall channel migration) has affected the distribution, abundance, and extent of such habitats.

\section{Changes in Vegetation Succession Patterns}

Historically, the Willamette River and its tributaries were flanked by broad, forested floodplains. The total area and species composi- tion of these forests, however, changed substantially during the 20th century. For example, along the Willamette River between Eugene and Newberg, the area of riparian forests decreased by about 60 percent between 1850 and 1990 (Gregory and others, 2002a). These forests were replaced with agricultural lands and developed areas, which now border about one-half of the main stem Willamette River. Similar transformations occurred on the tributaries (Gregory and others, 2002a) and along the main stem Willamette River in recent decades (David Hulse, University of Oregon, unpub. data).

Stand composition also has changed from hardwood forests bordering 75 percent of the length of the Willamette River in 1850 to hardwood and mixed forests each bordering less than 20 percent in 1990 (Gregory and others, 2002a). Other composition changes are related to introduced plant species. For instance, introduced plants now constitute more than one-third of the species at sites on the McKenzie and Willamette Rivers (Planty-Tabacchi and others, 1996; Fierke and Kauffman, 2006a; Cline and McAllister, 2012).

Within the geomorphic floodplain, streamflow changes, bank protection, and the resulting channel stability likely have benefited latesuccession plants over early pioneer plants. Largely uninterrupted by scouring during annual high flows, late-succession plants have successfully established themselves on formerly active gravel bars on river corridors throughout the study area during the mid-to-late 20th century (figs. 16, 20, and 21; Dykaar and Wigington, 2000; Gutowsky, 2000; Dykaar, 2005, 2008a, 2008b; Risley and others, 2010, 2012). 


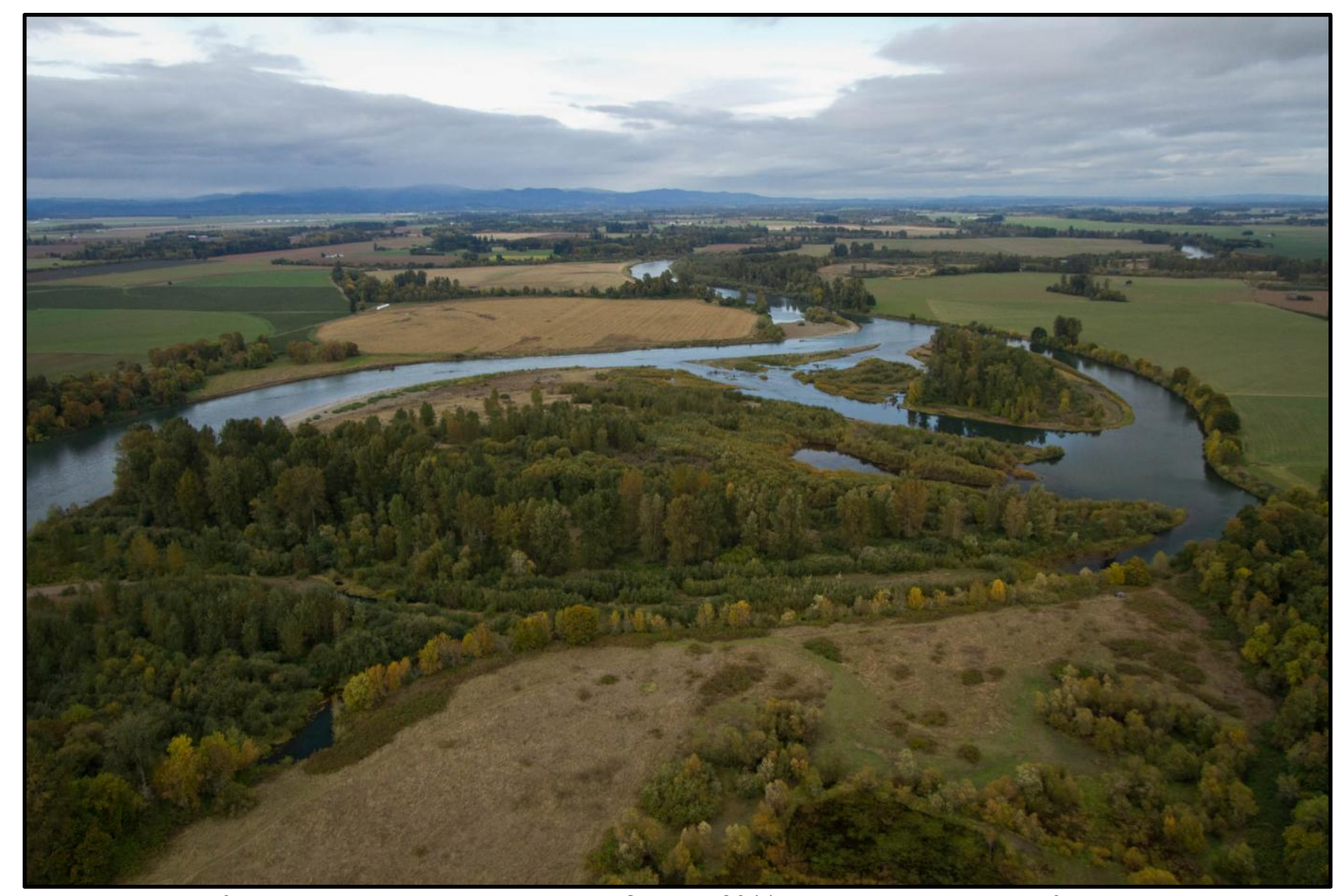

Upper segment of the Willamette River near Peoria, October 2011. Photograph courtesy of Freshwaters Illustrated.

Although riparian forests increased between 1990 and 2010 in the area inundated by the 2year recurrence interval flood (David Hulse, University of Oregon, unpub. data), there also have been areas of loss in the active channel area. A comparison of LiDAR data from 2008 with aerial photographs from 2012 shows decreases in forest area totaling 30 ha ( 75 acres) adjacent to the active channel in southern reaches of the Willamette River main stem.

Shade-intolerant pioneer plants such as black cottonwood, willow, and Oregon ash likely have limited germination sites because of the reduction in bars and islands, meander migration, and avulsions throughout the study area (figs. 11 and 12). As a result, stands of floodplain forest from 2011 appear less spatially diverse than forest stands from the mid-19th century and early 20th century (Gregory and others, 2002a; figs.16, 20, and 21). A qualitative review of aerial photographs taken in 2011 indicates fewer spatially diverse patches along the present-day floodplain (figs. 16B, 20, and 21; appendix A). Furthermore, although black cottonwood germination is successful along some existing active low-elevation gravel bars, frequent erosion of these bars during annual high flows prevents successful stand establishment (Cline and McAllister, 2012). Frequent scour of these bars and their early pioneer plants will likely continue as long as flows are concentrated within confined, incised, or single-thread reaches.

Flood-control operations that alter the magnitude, timing, and duration of flows also have implications for shade-intolerant pioneer plants throughout their life cycles (fig. 14). During seed 
dispersal in May, the regulated stage is lower on the Middle Fork Willamette and McKenzie Rivers than it was historically (Dykaar, 2008b; Risley and others, 2010), allowing seedlings to grow on low-elevation bars that are submerged later in summer. Between May and September, regulated flow recession is faster than unregulated conditions, corresponding to more days when flow recession rates may be lethal for black cottonwood because their roots cannot keep pace with the receding water levels (Dykaar, 2008b). Other hydrologic alterations that potentially hinder the growth of early-succession plants include (1) regulated summer flow that tends to be greater than unregulated summer flow, and may lead to prolonged inundation (Dykaar, 2008b; Risley and others, 2010), affecting the health and survival of black cottonwood seedlings growing on low-elevation bars; (2) peak-flow reduction, which decrease the transfer of nutrients between rivers and their floodplains; and (3) reduced hyporheic exchange, which can affect the survival of plants like black cottonwood, white alder, and forbs including sedges and rushes that derive their water from the shallow groundwater.

Altered flow and sediment regimes in the Willamette River Basin also can benefit some introduced species, such as reed canary grass and Japanese knotweed, which compete with native species for space and resources. These two species can reproduce from plant fragments, grow rapidly to prevent the growth of native plants, and thrive in a wide range of habitats (Gregory and others, 2007). Within the basin, introduced species are common in the alluvial valleys of the McKenzie and Willamette Rivers (Tabacchi and others, 1998) and are probably widespread in the alluvial valleys of other tributaries. Plants like reed canary grass, Himalayan blackberry, and climbing nightshade grow anywhere from bars to mature floodplain landforms on the main stem Willamette River (Fierke and Kauffman, 2006b).

\section{Geomorphic stability regimes}

The landforms and habitats of the presentday Willamette River floodplain reflect geological controls, historical conditions, anthropogenic alterations, and ongoing floodplain processes. Considering these influences and their implications for current and future riparian habitats, we have identified three categories related to channel stability: (1) geologically stable reaches, (2) artificially stable reaches, and (3) dynamic reaches. The descriptions below use examples from the nine valley segments (tables 3 and 4; Appendix A).

Geologically stable reaches occur throughout the study area where geologic features such as bedrock outcrops and Pleistocene terraces stabilize channel depth and position. Examples of geologically stable reaches are the main stem Willamette River flowing through the Salem Hills (near FPKM 115) and McKenzie River at Hayden Bridge, where the channel flows over and against bedrock outcrops (FPKM 14). At a broader scale, the middle and lower segments of the Willamette River are also considered geologically stable because the gradient in these segments is relatively low, and the river becomes increasingly entrenched between resistant Pleistocene terraces (tables 3 and 4; appendix A).

In comparison with more dynamic reaches, geologically stable segments have historically displayed lower rates of channel change, less complex channel planforms, and fewer side channels, gravel bars and islands. This is because the position of the river channel and gravel bars in these geologically stable reaches is largely fixed by valley physiography. Within geologically stable reaches, depositional zones have historically been key areas of channel shifting because they contain bars and floodplain surfaces that are more erodible than resistant Pleistocene terraces flanking the channel. For example, large bars and adjacent floodplain surfaces immediately up- 


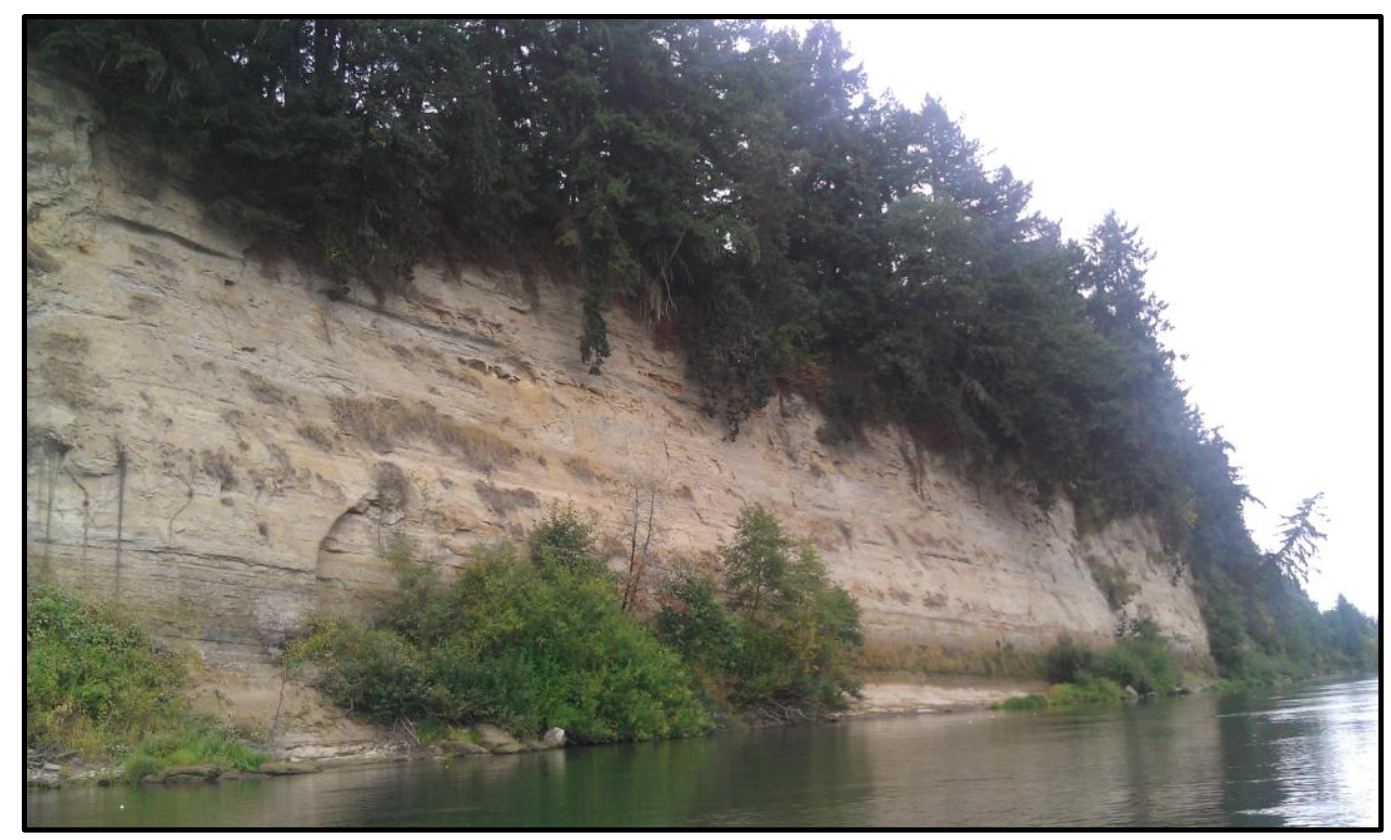

Missoula Flood deposits over resistant Pleistocene gravel $(\mathrm{Qg} 2)$ along the lower segment of the Willamette River near Buena Vista.

stream of Salem (FPKM 115) and the Newberg Pool (FPKM 80) have likely been depositional areas throughout the Holocene. As a result, depositional zones, together with tributary confluences, provide the greatest diversity of offchannel habitats and coldwater refugia in these predominantly single-thread reaches (Gregory and others, 2002b; Hulse and others, 2007; Wallick and others, 2007).

Artificially stable reaches were historically dynamic but have been stabilized, either directly by revetments or indirectly by substantially reduced flood peaks. The Santiam and South Santiam River segments are examples of reaches stabilized by extensive revetments, which limit meander migration, avulsions, bar growth, and overall channel complexity (table 4; appendix A; Fletcher and Davidson, 1988; Risley and others, 2012). The Middle Fork of the Willamette River has been locally stabilized by revetments but also because of reduced flood peaks and sediment supply, allowing vegetation succession on lowelevation bar surfaces (fig. 21; appendix A).

The imposed stability of these reaches influences the creation and maintenance of off- channel habitats like sloughs and side-channels created by channel shifting. For example, on the Middle Fork Willamette River sloughs that currently provide habitat for Oregon Chub were created in the historically more dynamic flow and sediment regime, but are now largely relict features that are filling with fine sediment.

Dynamic reaches are those that were historically dynamic and continue to have active meander migration and avulsions despite the effects of upstream dams and local bank stabilization. Dynamic reaches in general provide the greatest diversity of aquatic and riparian habitats under the current flow, sediment, and bank-stability regimes compared to the geologically or artificially stable reaches (for example, Gregory and others, 2002d). The upper segment of the Willamette River and the North Santiam River are the two reaches that most clearly retain dynamic characteristics (figs. 11 and 12; tables 3 and 4; appen$\operatorname{dix}$ A). These reaches, along with portions of the McKenzie River have long ( $>2 \mathrm{~km}$ ) sections of the channel flanked by erodible Holocene alluvium, bare gravel bars and low elevation floodplains. 
Table 3. Summary descriptions of channel characteristics for Willamette River, Oregon, and major salmon-bearing tributaries downstream of the U.S. Army Corps of Engineers dams-

[Descriptions are based on previous studies and qualitative assessments of aerial photographs, LiDAR, and maps of geology and USACE revetments (see table 1 for data sources). Abbreviations: FPKM, floodplain kilometer; USACE, U.S. Army Corps of Engineers; USGS, U.S. Geological Survey; m, meters; $\mathrm{m}^{2}$, square meters]

\begin{tabular}{|c|c|c|c|c|}
\hline Valley segment & FPKM & $\begin{array}{l}\text { Spatial extent of } \\
\text { alluvial, gravel bed } \\
\text { valley segment }\end{array}$ & $\begin{array}{l}\text { Water surface } \\
\text { slope }^{1} \\
\text { (percent) }\end{array}$ & Active channel description ${ }^{2}$ \\
\hline $\begin{array}{l}\text { Upper segment of } \\
\text { Willamette River }\end{array}$ & $168-228$ & $\begin{array}{l}\text { Corvallis to conflu- } \\
\text { ence of Coast and } \\
\text { Middle Fork } \\
\text { Willamette Rivers }\end{array}$ & 0.086 & $\begin{array}{l}\text { Predominantly single thread with some multi-thread sections. Numerous } \\
\text { actively shifting bars and side channels. }\end{array}$ \\
\hline $\begin{array}{l}\text { Middle segment } \\
\text { of Willamette } \\
\text { River }\end{array}$ & $166-138$ & $\begin{array}{l}\text { Confluence of the } \\
\text { Willamette and San- } \\
\text { tiam Rivers to Corval- } \\
\text { lis }\end{array}$ & 0.029 & $\begin{array}{l}\text { Single thread channel with few actively shifting gravel bars or side chan- } \\
\text { nels. Several large bars near FPKM } 85 \text {. }\end{array}$ \\
\hline $\begin{array}{l}\text { Lower segment of } \\
\text { Willamette River }\end{array}$ & 80-139 & $\begin{array}{l}\text { Upstream end of } \\
\text { Newberg Pool to the } \\
\text { confluence of the } \\
\text { Willamette and San- } \\
\text { tiam Rivers }\end{array}$ & 0.035 & $\begin{array}{l}\text { Single thread channel with more and larger gravel bars than the middle } \\
\text { segment. Large, actively shifting bars are upstream of Salem (FPKM 112- } \\
\text { 119) and the Newberg Pool (FPKM 80-93). Secondary channels abundant } \\
\text { below FPKM 9. }\end{array}$ \\
\hline $\begin{array}{l}\text { Coast Fork } \\
\text { Willamette River }\end{array}$ & $0-14$ & $\begin{array}{l}\text { Confluence with the } \\
\text { Middle Fork } \\
\text { Willamette River to } \\
\text { near Creswell }\end{array}$ & 0.157 & $\begin{array}{l}\text { Single thread, stable channel that is generally narrow and bordered by ma- } \\
\text { ture trees. Few side channels and gravel bars except for FPKMS 4-8. }\end{array}$ \\
\hline $\begin{array}{l}\text { Middle Fork } \\
\text { Willamette River }\end{array}$ & $0-22$ & $\begin{array}{l}\text { Confluence with Coast } \\
\text { Fork Willamette River } \\
\text { to Dexter Dam. }\end{array}$ & 0.219 & $\begin{array}{l}\text { Predominantly stable, single thread channel with some multi-thread sec- } \\
\text { tions (FPKM 15-17, 20-22). Active gravel bars are small and sparse } \\
\text { Densely forested, relict bars are along entire reach. Mature forests on low } \\
\text { bar surfaces. }\end{array}$ \\
\hline McKenzie River & $0-35$ & $\begin{array}{l}\text { Confluence with } \\
\text { Willamette River to } \\
\text { Deerhorn }\end{array}$ & 0.186 & $\begin{array}{l}\text { Predominantly single thread channel with some multi-thread sections. Nu- } \\
\text { merous bare gravel bars and side channels are above Hayden Bridge } \\
\text { (FPKM 14), but are generally smaller and sparser downstream. }\end{array}$ \\
\hline $\begin{array}{l}\text { North Santiam } \\
\text { River }\end{array}$ & $0-30$ & $\begin{array}{l}\text { Confluence with South } \\
\text { Santiam River to con- } \\
\text { fluence with Little } \\
\text { North Santiam River }\end{array}$ & 0.277 & $\begin{array}{l}\text { Channel has single-thread and multi-thread areas and numerous secondary } \\
\text { channels, ranging from recently formed alcoves and side channels to dense- } \\
\text { ly vegetated side channels. Large, actively shifting gravel bars are nearly } \\
\text { continuous between FPKM 5-12. }\end{array}$ \\
\hline
\end{tabular}


Table 3. Summary descriptions of channel characteristics for Willamette River, Oregon, and major salmon-bearing tributaries downstream of the U.S. Army Corps of Engineers dams—continued

[Descriptions are based on previous studies and qualitative assessments of aerial photographs, LiDAR, and maps of geology and USACE revetments (see table 1 for data sources). Abbreviations: FPKM, floodplain kilometer; USACE, U.S. Army Corps of Engineers; USGS, U.S. Geological Survey; m, meters; $\mathrm{m}^{2}$, square meters]

\begin{tabular}{|c|c|c|c|c|}
\hline Valley segment & FPKM & $\begin{array}{l}\text { Spatial extent of } \\
\text { alluvial, gravel bed } \\
\text { valley segment }\end{array}$ & $\begin{array}{l}\text { Water surface } \\
\text { slope }{ }^{1} \\
\text { (percent) }\end{array}$ & Active channel description ${ }^{2}$ \\
\hline $\begin{array}{l}\text { South Santiam } \\
\text { River }\end{array}$ & $0-20$ & $\begin{array}{l}\text { Confluence with North } \\
\text { Santiam River to Leb- } \\
\text { anon }\end{array}$ & 0.131 & $\begin{array}{l}\text { Channel is predominantly single thread with a few secondary channels and } \\
\text { gravel bars. More bars near confluence of Crabtree and Thomas Creeks } \\
\text { (FPKM 5-6). Large, densely vegetated relict bars are along entire valley } \\
\text { segment. }\end{array}$ \\
\hline $\begin{array}{l}\text { Main stem } \\
\text { Santiam River }\end{array}$ & $0-10$ & $\begin{array}{l}\text { Confluence of } \\
\text { Willamette River to } \\
\text { confluence of North } \\
\text { and South Santiam } \\
\text { Rivers }\end{array}$ & 0.087 & $\begin{array}{l}\text { Predominantly single thread channel except for short sections with second- } \\
\text { ary channels and large, active gravel bars (FPKM 0-7). Large, densely veg- } \\
\text { etated relict bars are along nearly the entire channel. }\end{array}$ \\
\hline
\end{tabular}

${ }^{1}$ Channel bed slope derived from water surface profile extracted from 2011 LiDAR (source information provided in table 1).

${ }^{2}$ See Appendix A for more complete descriptions and maps of valley segments.

Table 4. Summary descriptions of lateral and vertical stability for Willamette River, Oregon, and major salmon-bearing tributaries downstream of the U.S. Army Corps of Engineers dams.

[Descriptions are based on previous studies and qualitative assessments of aerial photographs, LiDAR, and maps of geology and USACE revetments (see table 1 for data sources). Abbreviations: FPKM, floodplain kilometer; USACE, U.S. Army Corps of Engineers; USGS, U.S. Geological Survey; m, meters; ${ }^{2}$, square meters]

\begin{tabular}{|c|c|c|c|}
\hline $\begin{array}{l}\text { Valley } \\
\text { segment }\end{array}$ & FPKM & Lateral stability trends & $\begin{array}{l}\text { Incision and aggradation trends near USGS streamflow-gaging } \\
\text { stations (from specific gage analyses) }\end{array}$ \\
\hline $\begin{array}{l}\text { Upper } \\
\text { segment of } \\
\text { Willamette } \\
\text { River }\end{array}$ & $168-228$ & $\begin{array}{l}\text { Dynamic segment that still displays } \\
\text { lateral migration and short avul- } \\
\text { sions despite extensive revetments. }\end{array}$ & $\begin{array}{l}\text { Channel incised a net } 0.75 \mathrm{~m} \text { between } 1945 \text { and } 1973 \text { and aggraded a net } 0.3 \mathrm{~m} \text { between } \\
\text { 1973-2012 (Harrisburg gage, fig. } 22 G \text { ). }\end{array}$ \\
\hline $\begin{array}{l}\text { Middle } \\
\text { segment of } \\
\text { Willamette } \\
\text { River }\end{array}$ & $166-138$ & $\begin{array}{l}\text { Geologically stable with historical- } \\
\text { ly low rates of meander migration } \\
\text { and avulsions. }\end{array}$ & $\begin{array}{l}\text { Channel was relatively stable between } 1879 \text { and } 1941 \text {, incised a net } 0.8 \mathrm{~m} \text { between } 1942- \\
1962 \text {, incised nearly } 0.5 \mathrm{~m} 1963-1975 \text {, and was relatively stable } 1976-2012 \text { (Albany gage, } \\
\text { fig. } 22 H \text { ). }\end{array}$ \\
\hline
\end{tabular}


Table 4. Summary descriptions of lateral and vertical stability for Willamette River, Oregon, and major salmon-bearing tributaries downstream of the U.S. Army Corps of Engineers dams—continued

[Descriptions are based on previous studies and qualitative assessments of aerial photographs, LiDAR, and maps of geology and USACE revetments (see table 1 for data sources). Abbreviations: FPKM, floodplain kilometer; USACE, U.S. Army Corps of Engineers; USGS, U.S. Geological Survey; m, meters; ${ }^{2}$, square meters]

\begin{tabular}{|c|c|c|c|}
\hline $\begin{array}{l}\text { Valley } \\
\text { segment }\end{array}$ & FPKM & Lateral stability trends & $\begin{array}{l}\text { Incision and aggradation trends near USGS streamflow-gaging } \\
\text { stations (from specific gage analyses) } \\
\end{array}$ \\
\hline $\begin{array}{l}\text { Lower } \\
\text { segment of } \\
\text { Willamette } \\
\text { River }\end{array}$ & 80-139 & $\begin{array}{l}\text { Geologically stable with historical- } \\
\text { ly low rates of meander migration } \\
\text { and avulsions. }\end{array}$ & $\begin{array}{l}\text { Channel incised a net } 1 \text { m between } 1909 \text { and 1962, aggraded about } 0.3 \text { m between } 1962 \text { and } \\
1965 \text { (probably due to } 1964 \text { flood, incised } 0.3 \text { m between } 1965 \text { to 2012, overall resulting in } \\
\text { very little net overall change from } 1962 \text { to } 2012 \text { (Salem gage, fig. 22I). }\end{array}$ \\
\hline $\begin{array}{l}\text { Coast Fork } \\
\text { Willamette } \\
\text { River }\end{array}$ & $0-14$ & $\begin{array}{l}\text { Stable because of geology and re- } \\
\text { vetments. }\end{array}$ & $\begin{array}{l}\text { Channel aggraded about 0.1-0.2 m between } 1905 \text { and } 1912 \text {. Gage discontinued 1912-1950. } \\
\text { Channel lowered about a net } 0.3 \mathrm{~m} \text { between } 1950 \text { and } 2012 \text { (Goshen gage, fig. 22E). }\end{array}$ \\
\hline $\begin{array}{l}\text { Middle Fork } \\
\text { Willamette } \\
\text { River }\end{array}$ & $0-22$ & $\begin{array}{l}\text { Artificially stable due to revetments } \\
\text { and reductions in floods and coarse } \\
\text { sediment. }\end{array}$ & $\begin{array}{l}\text { Channel aggraded about } 0.5 \mathrm{~m} \text { between } 1905 \text { and 1916, incised about } 0.5 \mathrm{~m} \text { from } 1916 \text { to } \\
\text { 1952, and was relatively stable } 1952-2012 \text { (Jasper gage, fig. } 22 D \text { ). }\end{array}$ \\
\hline $\begin{array}{l}\text { McKenzie Riv- } \\
\text { er }\end{array}$ & $0-35$ & $\begin{array}{l}\text { Valley segment with dynamic sec- } \\
\text { tions, geologically stable sections, } \\
\text { and areas stabilized with revet- } \\
\text { ments. }\end{array}$ & $\begin{array}{l}\text { Channel incised a net } 0.5 \mathrm{~m} \text { from } 1944 \text { through autumn } 1964 \text {, and aggraded about } 0.7 \mathrm{~m} \text { dur- } \\
\text { ing December } 1964 \text { flood. Between } 1965 \text { and } 1972 \text {, channel incised about } 1.3 \mathrm{~m} \text {. Gage dis- } \\
\text { continued October } 1972 \text { through } 2006 \text {. Measurements at new location show no change in } \\
\text { bed elevation from } 2007 \text { to } 2008 \text { (Coburg gage, fig. } 22 F \text { ). }\end{array}$ \\
\hline $\begin{array}{l}\text { North } \\
\text { Santiam River }\end{array}$ & $0-30$ & $\begin{array}{l}\text { Dynamic valley segment with areas } \\
\text { of active migration and avulsions. } \\
\text { Few revetments. Locally, the chan- } \\
\text { nel flows against resistant Pleisto- } \\
\text { cene terraces and bedrock outcrops }\end{array}$ & $\begin{array}{l}\text { Channel was stable from } 1907 \text { to } 1914 \text {. Gage discontinued 1914-1921. Between } 1921 \text { and } \\
1956 \text {, bed elevations show little net change. Channel aggraded about a net } 0.2 \mathrm{~m} \text { between } \\
1956 \text { and } 1985 \text { and } 0.1 \mathrm{~m} \text { from } 1985 \text { to } 2012 \text {. Gage is located about } 5 \mathrm{~km} \text { upstream of the al- } \\
\text { luvial portion of North Santiam River in a reach confined by Pleistocene terraces. Trends } \\
\text { may not be representative of unconfined segments downstream (Mehama gage, fig. } 22 \mathrm{~A} \text { ). }\end{array}$ \\
\hline $\begin{array}{l}\text { South } \\
\text { Santiam River }\end{array}$ & $0-20$ & $\begin{array}{l}\text { Artificially stable mainly because } \\
\text { of extensive revetments. }\end{array}$ & $\begin{array}{l}\text { Channel was very stable between } 1923 \text { and } 2012 \text {. Channel at this site is likely controlled by } \\
\text { in-channel bedrock. Trends are probably not representative of historically meandering (but } \\
\text { extensively revetted) segments downstream (Waterloo gage, fig. 22B) }\end{array}$ \\
\hline $\begin{array}{l}\text { Main stem } \\
\text { Santiam River }\end{array}$ & $0-10$ & $\begin{array}{l}\text { Artificially stable mainly because } \\
\text { of extensive revetments. }\end{array}$ & 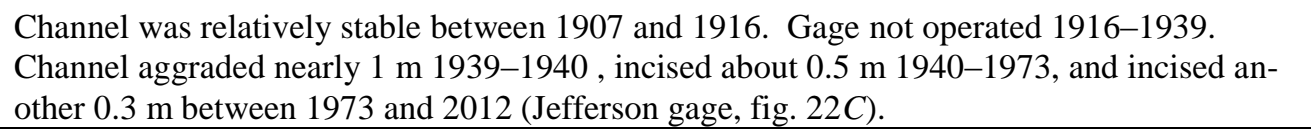 \\
\hline
\end{tabular}

${ }^{1}$ Specific gage analysis summary taken primarily from stage changes at low flows (95 and 75 percent exceedence flows); see figure 22 for data

${ }^{2}$ See Klingeman (1973) for discussion and interpretation of bed level changes at all sites prior to 1970s. Risley and others (2010) provides more in-depth descriptions for sites in the McKenzie Basin. 


\section{The Future Willamette River Floodplain}

Alterations to the geomorphology of the Willamette River Basin and the historical and ongoing responses of the channel and vegetation to those alterations have established trajectories of channel and floodplain change that will continue to affect the Willamette River system in the future. Some trajectories are probably ubiquitous throughout the entire river system because of the fundamental changes in flow and sediment transport. Other changes will vary among reaches because of characteristics like channel stability, which limit channel adjustments to changes in flow, sediment, and bank stability.

For certain aspects of the Willamette River and its tributaries, we can predict future conditions on the basis of historical conditions, trends, and understanding of key processes. Other aspects will require better understanding of the consequences of altered sediment, wood, and flow regimes, as well as the outcomes of management and policy actions that affect channels and floodplain processes and conditions. Efficient and effective restoration and conservation will benefit from full and comprehensive understanding of present trajectories and their relation to past, present, and future process regimes.

\section{A Smaller "Functional Floodplain"}

One outcome of the changed hydrologic and sediment regime is a reduced aerial extent of active channel and floodplain processes. This diminished area affected by hydrologic and geomorphic processes of the present fluvial regime can be termed the "functional floodplain" (Opperman and others, 2010). Whereas the geomorphic floodplain reflects historical sediment, wood, and water conditions, the functional floodplain reflects the current flow and sediment regime. The functional floodplain is inset within the much broader geomorphic floodplain, so both contain active channel areas of bed-material transport, as well as flanking floodplain areas dominated by overbank deposition of suspended

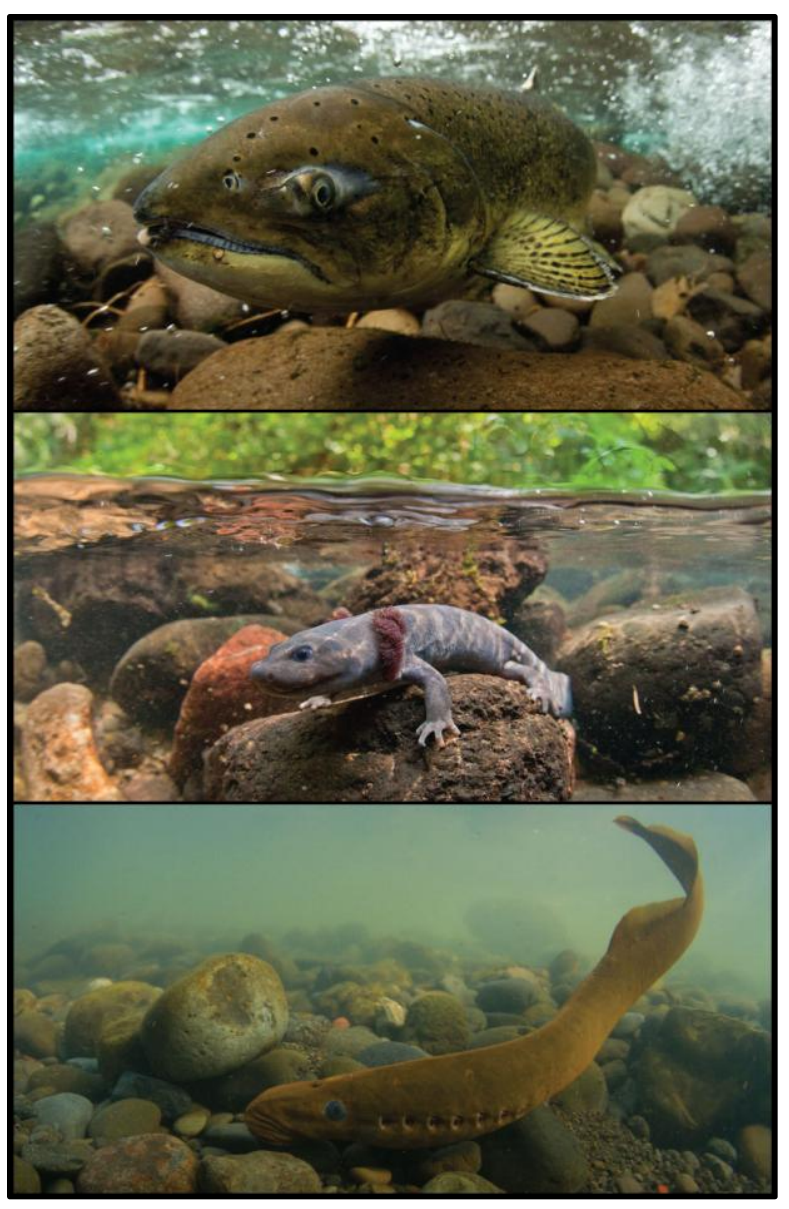

Examples of aquatic species residing in the rivers and floodplains of Willamette River Basin. From top to bottom: Spring Chinook Salmon in South Fork McKenzie River above Cougar Reservoir, September 2012; Larval Pacific Giant Salamander, Moose Creek, September 2012; Pacific Lamprey in spawning habitat, Thomas Creek, May 2012. Photographs courtesy of Freshwaters Illustrated.

sediment. However, because the inundation extent of modern floods is much more limited than historical (pre-dam) floods, the functional floodplain is much narrower (fig. 23).

Implications of a reduced functional floodplain may include adjusting restoration frameworks to identify where processes are active today. The first step would be defining the functional floodplain from existing datasets (fig. 23). A second implication is that channel and floodplain features evolve over time and will continue to do so within and outside of the current func- 
tional floodplain. Within the functional floodplain, landforms and habitats may become less diverse over time because of the overall decrease in the intensity of fluvial processes. Areas historically affected by Holocene geomorphic processes (but now bordering the functional floodplain) may transition to stable floodplain surfaces mainly affected by overbank deposition.

Farther away from the functional floodplain, posed largely of relict features that are not affected by modern fluvial processes. These areas probably will continue to evolve mainly through terrestrial processes and vegetation succession, depending on the extent and frequency of nowrare overbank flooding. It is unlikely that these relict areas will contribute substantially to future riparian and aquatic habitats without significant alteration to overall river conditions. the remaining geomorphic floodplain is com-

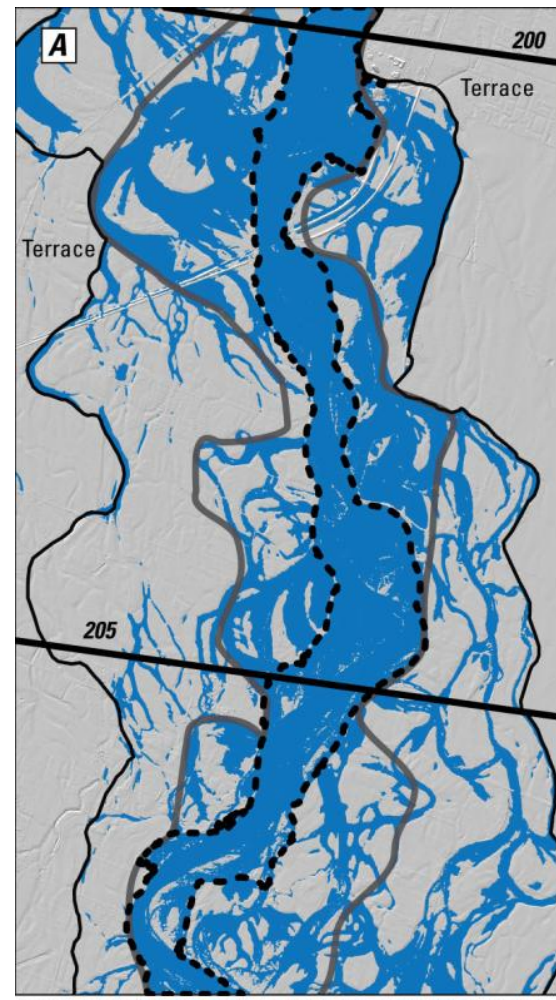

Base map modified from Oregon Department of Geology and Mineral Industries, River Design Group, U.S. Geological Survey, and U.S. Department of Agriculture, digital data, various scales. UTM Zone 10N, NAD 1983
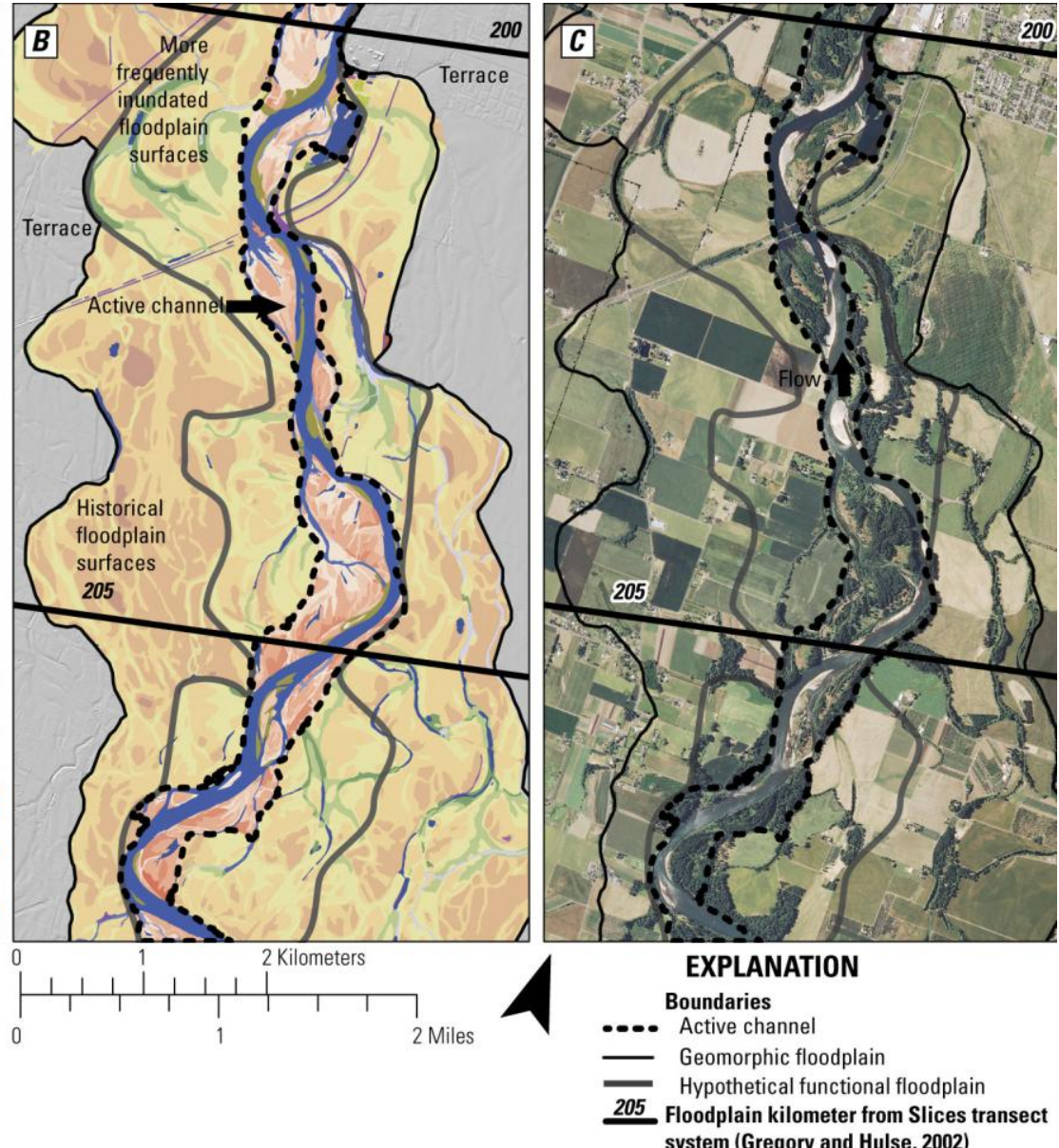

Figure 23. Relations among major floodplain elements reflecting dominant historical and current process regimes on the upper segment of the Willamette River, Oregon, near floodplain kilometer 205. The geomorphic floodplain is the product of historical sediment and flow conditions and its boundary coincides approximately with the Holocene floodplain (after O'Connor and others, 2001). The functional floodplain is inset within the geomorphic floodplain and is actively shaped and modified by current flow and sediment transport conditions. Here, the limits of functional floodplain are not known but are speculatively represented. The active channel is the area of frequent bed-material transport and its boundary is based on the 2012 geomorphic mapping pilot study by the U.S. Geological Survey (USGS). A. Two-year recurrence interval flood inundation from River Design Group, Inc. (2012b). B. Active channel and floodplain landforms from 2012 pilot study of detailed geomorphic mapping by USGS (see figure 5 for explanation of map units). C. Aerial photographs from 2011. 


\section{Variation in Responses at the Reach Scale}

Although the spatial extent and diversity of landforms within the functional floodplain probably have decreased and will continue to do so in all reaches, specific conditions will depend on specific reach characteristics. For most responses, however, the overarching controls likely will owe to channel stability.

Geologically stable reaches will likely have minimal vertical and lateral adjustments because of the resistant materials forming their beds and banks. Consequently, these reaches are probably less sensitive to changes in flow and sediment regimes. Artificially stable reaches are also likely to have few morphological changes in coming decades in the absence of changes in bank stabilization, flow, or sediment supply. Without such changes, we may expect the longterm decline of features like off-channel habitats that were created by the historical flow and sediment regime.
Dynamic reaches will likely continue to provide the greatest diversity of aquatic and riparian habitats under the current flow and sediment regime. Dynamic reaches may have areas where revetments or geology impose local restrictions on channel migration but are generally unconfined and flanked by erodible bank materials. Past work shows these reaches are more responsive to flow and sediment changes than geologically stable reaches. For example, the dynamic, upper segment of the Willamette River has had greater historical decreases in side channels, islands, and overall rates of channel change compared to the more stable, middle and lower segments of the Willamette River (Gregory and others, 2002b; Wallick and others, 2007; Gregory, 2008). Because the morphology of these reaches can dynamically adjust to changes in flows, sediment supply, and bank erodibility, they are likely to be most sensitive to future climatic variation or management actions.

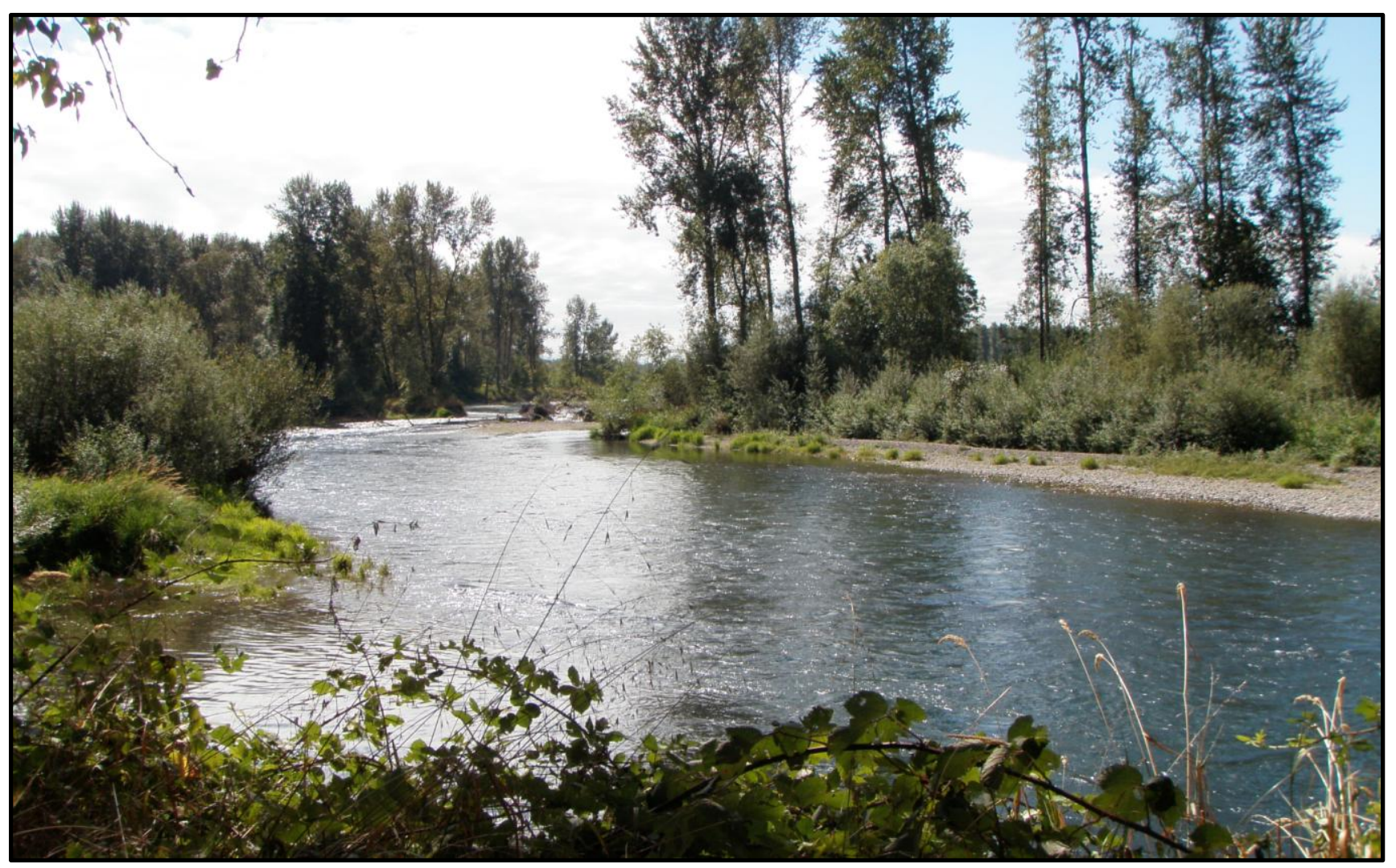

Side channel on upper segment of the Willamette River near Green Island (FPKM 214), August 2012. 


\section{Unknowns and Next Steps}

This report summarizes the state of knowledge about geomorphic processes shaping landforms, habitats, and vegetation along river corridors in the present-day Willamette River Basin. One conclusion from this synthesis is that flow, sediment, and wood regimes have changed fundamentally during the last 150 years, culminating in the emergence of the modern Willamette River channel and floodplain. Some characteristics of the present system are altered streamflows, reduced rates of meander migration and channel avulsion, less input and transport of large wood, and diminished sediment supply. Despite these changes, the modern Willamette River has many of the physical, ecological, and political building blocks for a highly functioning river corridor. Although the legacies of past changes impose constraints, many of these are isolated or can be mitigated by judicious management and use of present resources and opportunities, especially if implemented in accordance with a process-based understanding of river and floodplain function.

Another conclusion is that substantial gaps exist in contemporary understanding of geomorphic processes in the modern Willamette River Basin. Existing analyses of historical channel patterns provide insight into how the river once behaved, but have limited applications in the modern system where flow, sediment, and channel behavior have changed substantially.

\section{Key Questions}

The following four key questions address these knowledge gaps. This list is not exhaustive: it is guided by the current restoration and conservation strategies and opportunities now being implemented or considered in the basin (as described in the Introduction) and the need for focused inquiries on the current status of the floodplain and interactions between streamflow, sediment, and vegetation.

\section{Question 1: What is the distribution and diver- sity of landforms and habitats along the Willamette River and its tributaries?}

While major types of active channel and floodplain features in the Willamette River Basin generally are known, more detailed understanding of these features is lacking. Along the main stem Willamette River, the Slices framework provides maps of some channel features and measures of channel complexity. In addition, this synthesis report has examples of channel and floodplain features from USGS pilot mapping (figs. 5 and 6). Nevertheless, still largely unknown is the full distribution and diversity of specific landforms and habitats along the channels and floodplains of the present-day main stem Willamette River and its tributaries.

A complete landform and habitat inventory would address this issue by providing a census of present-day conditions. This would be similar to the ecosystem classification mapping for the lower Columbia River and floodplain (Simenstad and others, 2011). Such mapping could be readily integrated into the existing Slices framework, and would facilitate expanding the Slices database to the tributaries.

The inventory's objective would be to define spatially discrete landform units with similar geomorphic characteristics and formative processes, and then to relate these features to riparian habitats. In a recent pilot project, the USGS developed Willamette-specific mapping protocols for the geomorphic floodplain of the main stem river (figs. 5 and 6). These protocols are ready for wider implementation and tailoring to the tributaries.

Detailed landform and habitat mapping for the Willamette River main stem and major salmon-bearing tributaries would aid several restoration and conservation activities:

- A completed inventory would be the basis for identifying areas with different active processes, such as channel areas actively shaped by coarse sediment transport and 
channel migration, floodplain areas actively shaped by occasional inundation and fine sediment deposition, or geomorphically stable landforms mainly changing with vegetation succession.

- High resolution geomorphic mapping would facilitate delineation the functional floodplain for the current flow and sediment transport regime.

- A spatial inventory of landforms could support other products such as maps of channel networks, hydrologic connectivity between different habitats, depths to groundwater, and anthropogenic floodplain modifications.

- A comprehensive habitat inventory is a baseline for evaluating and demonstrating restoration success and assessing habitat change. If done at regular intervals (for example, every 5 years) or following large floods, the inventory would be beneficial for tracking and assessing cumulative landform and habitat changes in relation to environmental flow releases and implementation of restoration and conversation strategies.

- A consistent database of landforms and habitats for both the tributaries and main stem would be beneficial for characterizing the broad status and distribution of habitats in the present-day Willamette River Basin and collaboratively evaluating and prioritizing habitat improvements in the basin as a whole.

- A spatially explicit means for linking habitats supporting fish, wildlife, and plants to specific landforms would support process-based restoration actions targeted at specific habitats. For instance, ongoing efforts are identifying "fish catena" using the ecosystem classification for the lower Columbia River to help quantify potential rearing habitat for subyearling Chinook Salmon (University of Washington and others, 2011).

- At the scale of individual restoration projects, detailed mapping of landforms, habi- tats, and vegetation could provide historical and spatial context. The inventory would help with assessing historical trends and identifying and locating habitats and landforms of concern.

\section{Question 2: What is the footprint of today's functional floodplain?}

The functional floodplain is the area where present-day fluvial processes of flooding, sediment and wood transport, and riparian vegetation colonization and succession actively interact to create and refresh habitats. The area of the functional floodplain tends to be greatest in unconfined, low-gradient reaches and lowest in confined, high-gradient reaches. The functional floodplain can contract or expand in response to changes in flow and sediment regimes. For instance, it may become narrower in drier climate periods, when streamflow is less effective at overtopping banks or when stream incision hinders hydrologic connectivity between channels and floodplains.

The information on valley segments presented in appendix A is the first step toward determining the extent of the present-day functional floodplain. Today, the Middle Fork Willamette, Santiam, and South Santiam River segments are expected to have narrower functional floodplains because peak streamflows are especially reduced by dams on the Middle Fork Willamette River, and channel change and bar growth are limited by extensive revetments on the Santiam and South Santiam Rivers. Segments less affected by flow regulation and revetments, like the upper Willamette River, experience more channel change annually as high flows cause meander migration and avulsions.

Moving from these general statements to determining the boundaries of the present-day functional floodplain will require consideration of the landform and habitat inventory (question 1 ), inundation maps and streamflow data (fig. 23 ), and all key processes and conditions presently affecting the fluvial corridors in the 
Willamette Basin. Delineation of the functional floodplain in conjunction with the landform and habitat inventory would be logical approach for developing this information.

Some benefits of defining the functional floodplain are:

- Providing consistent identification of areas where process-based restoration may be most effective in the Willamette River Basin under current flow and sediment regimes. This would be beneficial for focusing restoration activities and for setting realistic restoration expectations given the present-day constraints on habitat-forming processes.

- Providing information on geomorphic and hydrologic processes relevant to site-specific restoration. For instance, identification of areas where restored side channels may be expected to be routinely scoured or, in contrast, will accumulate fine sediment, which may need to be removed to maintain hydrologic connectivity.

- Providing a basis for broadscale monitoring of the active floodplain area and its response to environmental flow releases and revetment modifications.

\section{Question 3: How are landforms and habitats in the Willamette River Basin created and re- shaped by present-day flow and sediment conditions?}

The dominant, large-scale processes shaping the floodplains of the Willamette River and its major tributaries are flooding, coarse sediment transport, and vegetation succession. They, in turn, drive channel avulsion, meander migration, channel incision, and aggradation. All these processes ultimately create and reshape aquatic and floodplain landforms. Although fundamentally altered by dam construction and bank stabilization, these processes still operate in the modern Willamette River Basin. Environmental flow releases and revetment modifications are options under consideration to mitigate the effects of some alterations and to strengthen these natural river processes. A key unanswered question, however, is "what specific landforms and habitats throughout the basin are shaped and refreshed by present-day sediment and flow processes?" This question has many related ones, including "what are effective streamflow targets for maintaining certain habitats of concern?" and "given the sediment trapping by the dams (fig. 19), to what extent is the slowing incision at USGS gaging stations (fig. 22) reflective of overall changes in river bed elevation?"

Answering this question requires desktop analyses and field data collection. Following the approach of prior USGS studies (Wallick and others, 2010, 2011), tasks could include:

- Repeat (or sequential) mapping of vegetation and channel change from aerial photographs that strategically bracket different magnitude high flows. Rates and styles of channel change relative to changes in streamflow and sediment transport are then determined from map results. Such information builds on existing assessments of historical changes in main stem islands from 1850 to 1995 (Gregory, 2008), and is applicable to examining vegetation succession trends relative to channel change and flooding.

- Analyses of repeat channel surveys to assess trends in channel incision and aggradation for valley segments.

- Quantification of longitudinal patterns in bed-material sediment supply and rivers' ability to move sediment. This task may require multifaceted analyses of bed-material characteristics, bed-material transport capacity, and sediment transport rates.

Expected restoration and conservation applications of this information on geomorphic processes active in the modern Willamette River Basin include:

- Quantitative knowledge of habitat-forming processes to support and justify quantitative restoration and conservation objectives. 
- A basis for monitoring strategies to assess restoration effectiveness and habitat status and trends.

- Estimates of changes in transport capacity owing to upstream dams. To date, estimates only have been calculated for the South Santiam River (Fletcher and Davidson, 1988).

- More complete information on channel incision and aggradation trends throughout the basin, including causal mechanisms. At the restoration site scale, such information would help tailor restoration practices to local conditions and expected future trends. For instance, in an incising reach hydrologic connectivity between restored side channels and the main stem may require ongoing maintenance. Alternatively, aggrading channel segments may be logical candidates for effectively reintroducing channel migration.

- The identification of reaches with different characteristics. For example, maps could be created showing where (1) processes are largely functioning, making such reaches candidates for process-based restoration; (2) sediment transport processes are replenishing and continually building gravel deposits; (3) transport capacity greatly exceeds sediment supply, making such reaches susceptible to further decreases in gravel bar area, continuing channel incision, or bed coarsening; and (4) the channel is incising, diminishing lateral connections between the river and floodplain, or aggrading.

- Identification of the range of flood magnitudes needed for native vegetation establishment and recruitment as well as geomorphically effective flows for creating and maintaining habitats such as side channels.

- Context for understanding types and rates of channel meander migration and avulsion in the modern Willamette River Basin and channel response to restoration activities such as environmental flow releases and revetment modifications.
- Plans for revetment modifications may benefit from considering bed-material transport processes because local bank erosion may promote downstream bar growth, enhancing channel complexity but also potentially increasing bank erosion elsewhere.

\section{Question 4: How is the succession of native floodplain vegetation shaped by present-day flow and sediment conditions?}

Floodplain forests provide many benefits to aquatic and riparian ecosystems along the Willamette River and its major tributaries. Recent studies indicate that stand initiation in some areas is limited by the current flow and sediment conditions and bank stabilization. In these areas, existing stands of vegetation continue to mature without disturbance owing to overall channel stabilization, which may, in turn, contribute to further channel stabilization and simplification of channel morphology. Together, these trends may substantially change the diversity and abundance of future floodplain forests. These changes may also continue to stabilize and confine channels and reduce the area of the functional floodplain. At present, knowledge defining these trends and options for mitigation is incomplete.

Analyses to address these issues have been started with studies of floodplain vegetation at sites on the upper segment of the Willamette River between Eugene and Harrisburg, the McKenzie River, and the Coast and Middle Forks of the Willamette River (Planty-Tabacchi and others, 1996; Dykaar and Wigington, 2000; Gutowsky, 2000; Dykaar, 2005, 2008a, 2008b Fierke and Kauffman, 2006a; Cline and McAllister, 2012). Building on these findings would be assisted by reach-wide assessments of floodplain vegetation. Next steps would be (1) comparing floodplain landforms with maps of vegetation communities and depths to groundwater to assess availability of suitable sites for stand initiation, (2) evaluating temporal trends in vegetation communities during recent decades using aerial photography, (3) combining findings from previ- 
ous tasks with reach-specific hydrologic analyses to determine the streamflow characteristics needed to erode or disturb different seral stages of vegetation, and (4) determine streamflow hydrograph properties associated with successful germination and colonization of new habitats.

Broadscale understanding of the relationships between sediment, flow, and vegetation would provide:

- Initial reach-wide vegetation assessments that provide baselines for future monitoring and restoration effectiveness assessments.

- Information on the duration and magnitude of flows needed to erode different ages and densities of vegetation and to entrain stored gravel deposits.

- Information on elevation zones, where the establishment of pioneer vegetation is likely based on bar topography, unvegetated gravel deposits, and depth to groundwater. Such information would be helpful to prioritize planting locations and for identifying sites to target monitoring of the effectiveness of environmental flow releases for the restoration of native vegetation, like black cottonwood and willows.

- Reach-scale data on specific biophysical conditions pertinent for riparian vegetation restoration projects, such as the length and frequency of summer inundation and lethal recession rates for species of concern like black cottonwood.

- Framework information for designing management strategies to address introduced plant species.

\section{Next Steps}

The answers to these questions will produce baseline information on the current distributions of landform and habitats (question 1), the extent of the functional floodplain (question 2), and the effects of modern flow and sediment regimes on future floodplain landforms, habitats, and vegetation succession (questions 3 and 4). Of these, questions 1 and 2 are the logical starting points because a landform and habitat inventory and functional floodplain map would serve as the basis for addressing questions 3 and 4.

As these questions are addressed for the entire study area, continued consideration of the differences among reaches, in places supported by finer-scale analyses, will provide even more support in tailoring restoration strategies to local conditions and processes. The priorities and scope for more detailed analyses may in part become evident from broadscale analyses, but is more likely to depend on evolving basin-scale restoration priorities resulting from social and political processes.

All actions aimed at questions $1-4$ at all scales will benefit by frequent discussions among researchers and the Willamette River Basin restoration community. Such interactions would support continuing adjustment of research questions and activities so as to meet restoration and conservation needs as opportunities and approaches (and regulatory conditions) evolve.

However these efforts unfold, restoring a highly functional river corridor and associated biological communities in the basin has the greatest chance of success if conducted with an understanding of flow, sediment, and channel change because they are the physical building blocks buttressing the ecology and biology of the present-day and future Willamette River Basin.

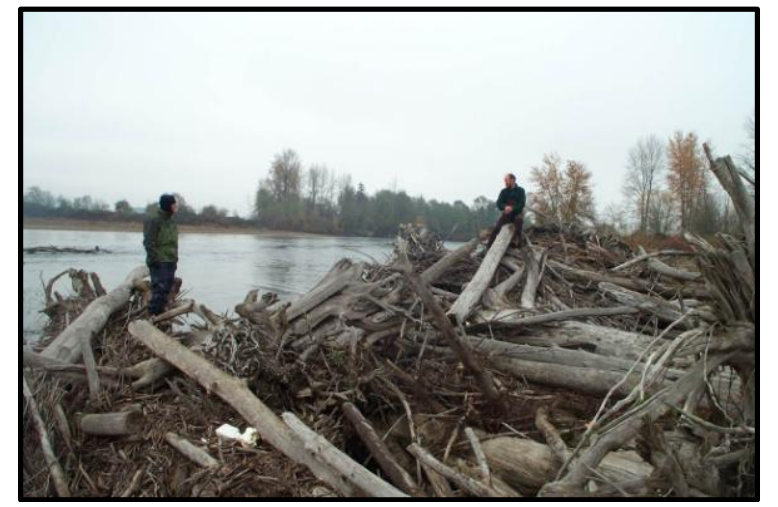

Large wood jam near Sam Dawes Landing on the upper segment of the Willamette River, December 2003. Photograph courtesy of Gordon Grant. 


\section{Conclusions}

The floodplains and stream channels of the Willamette River and its major, salmon-bearing tributaries downstream of the USACE dams have undergone substantial transformations in the last 150 years. Changes include widespread reductions in the number and area of gravel bars, islands, and side channels. Most of these changes correspond with decreased lateral channel movement and local channel incision. Most of these broadscale changes are consequences of decreases in the frequency and magnitude of floods, diminished supply of coarse sediment and large wood, and local isolation of the floodplain from fluvial processes. Together, these changes result in a modern Willamette River Basin with a narrower functional floodplain and substantially reduced intensity and extent of habitat-forming processes in the active channel and floodplain. This basin also has riparian forests that are largely aging in place, whereas the establishment of young stands is limited by a paucity of suitable sites that support stand initiation and succession.

Despite these profound changes, many of the essential physical processes remain in place for creating and sustaining an ecologically functional river corridor. Moreover, recent efforts and opportunities for restoration and conservation, including environmental flow programs, habitat restoration efforts, revetment modifications, and reclamation of gravel mines, provide a path forward in this direction. Efficient and effective attainment of an ecologically functional Willamette River would benefit, however, from narrowing several key knowledge gaps. Actions to address these include (1) developing an inventory of present-day landforms and habitats within geomorphic floodplains flanking the river corridors, (2) delineate the current functional floodplains where present-day fluvial processes actively create and maintain dynamic channel and floodplain habitats, (3) obtain quantitative understanding of the relations between present-day flow and sediment conditions and resulting land- forms and habitats, and, similarly, (4) develop understanding of how succession of native floodplain vegetation is affected by current flow and sediment conditions.

\section{Acknowledgments}

Sarah Schanz conducted the pilot geomorphic mapping, and Joseph Mangano assisted with mapping, field data collection, and analysis of historical datasets. This study benefited from the collaboration and insights of several individuals, organizations, and institutions focused on Willamette River floodplain management. Ken Bierly, Oregon Watershed Enhancement Board (retired), Wendy Hudson, Oregon Watershed Enhancement Board, and Pam Wiley and Eric Jones, the Meyer Memorial Trust, provided the framework, initial funding and helpful reviews. Holly Crosson and Jennifer Ayotte (retired), Benton Soil and Water Conservation District, oversaw the USGS part of the study. Several scientists and resource managers provided information, site visits, and insights into the basin, including Peter Klingeman, Professor Emeritus, Oregon State University; Gordon Grant, U.S. Forest Service; Greg Taylor, USACE Portland District; Brian Bangs, Oregon Department of Fish and Wildlife; Steve Cline, U.S. Environmental Protection Agency, Western Ecology Division; Anne Mullan, National Oceanic and Atmospheric Administration, Fisheries; Steve Smith, U.S. Fish and Wildlife Service (retired); Kendra Smith, Bonneville Environmental Foundation; Troy Brandt and Scott Wright, River Design Group, Inc.; Chris Vogel and Joe Moll, McKenzie River Trust; Leslie Bach, Dan Bell, Jason Nuckols, and Emilie Blevins, The Nature Conservancy; and Isaac Sanders and Vaughn Balzer of Oregon Department of Geology and Mineral Industries. Christine Budai, Keith Duffy, and Mary Karen Scullion, USACE, Portland District, have helped us to better understand Willamette Project flood-control operations and have supported our ongoing environmental flow studies. Jeremy Monroe, Freshwaters Illustrated, provided photographs of the Willamette River. 


\section{References Cited}

Achterman, G.L., Williamson, K., Lundy, J., Klingeman, P.C., Jarvis, W.T., and Littlefield, S., 2005, Preliminary summary of aggregate mining in Oregon with emphasis in the Willamette River Basin: Corvallis, Oregon, Institute for Natural Resources, Project Final Report 2005-06, 51 p., accessed August 20, 2013, at http://ir.library.oregonstate.edu/xmlui/handle/ 1957/13914.

Andrews, E.D., 1983, Entrainment of gravel from naturally sorted riverbed material: Bulletin of the Geological Society of America, v. 94, p. 1225-1231.

Andrews, E.D., 1984, Bed-material entrainment and hydraulic geometry of gravel-bed rivers in Colorado: Bulletin of the Geological Society of America, v. 95, p. 371-378.

Bangs, B.L., Scheerer, P.D., and Miller, S.A., 2011, Effects of U.S. Army Corps of Engineers Willamette Projects operations on Oregon chub and other floodplain fishes (20092010): Corvallis, Oregon Department of Fish and Wildlife Fish Division, Progress Report, 140 p., accessed August 20, 2013, at http://oregonstate.edu/dept/ODFW/NativeFish /pdf_files/ODFWFloodplainProgressReport_2 009-2010.pdf.

Bellmore, J.R., Colden, V.B., Martens, Kyle, and Connolly, P.J., 2013, The floodplain food web mosaic - A study of its importance to salmon and steelhead with implications for their recovery: Ecological Applications, v. 23, p. 189207, accessed August 22, 2013, at http://www.esajournals.org/doi/abs/10.1890/1 2-0806.1http:/dx.doi.org/10.1890/12-0806.1.

Benner, P.A., and Sedell, J.R., 1997, Upper Willamette River landscape-A historic perspective, in Laenen, Antonious, and Dunnette, D.A., eds., River quality-Dynamics and restoration: Salem, Massachusetts, CRC Press, Inc., p. 23-47.
Burkholder, B.K., Grant, G.E., Haggerty, R., Khangaonkar, T., and Wampler, P.J., 2008, Influence of hyporheic flow and geomorphology on temperature of a large, gravel-bed river, Clackamas River, Oregon USA: Hydrological Processes, v. 22, p. 941-953.

Church, M., 2006, Bed material transport and the morphology of alluvial river channels: Annual Review of Earth and Planetary Sciences, v. 34, p. 325-354.

Church, Michael, 1988, Floods in cold climates, in Baker, V.R., Kochel, R.C., and Patton, P.C., eds., Flood geomorphology: New York, Wiley, p. 205-229.

Cline, S.P., and McAllister, L.S., 2012, Plant succession after hydrologic disturbanceInferences from contemporary vegetation on a chronosequence of bars, Willamette River, Oregon, USA: River Research and Applications, v. 28, p. 1519-1539.

Collins, B.D., Montgomery, D.R., Fetherston, K.L., and Abbe, T.B., 2012, The floodplain large-wood cycle hypothesis-A mechanism for the physical and biotic structuring of temperate forested alluvial valleys in the North Pacific ecoregion: Geomorphology, v. 139140, p. 460-470.

Colvin, Randall, Giannico, G.R., Li, Judith, Boyer, K.L., and Gerth, W.J., 2009, Fish use of intermittent watercourses draining agricultural lands in the upper Willamette River Valley, Oregon: Transactions of the American Fisheries Society, v. 138, p. 1302-1313.

Dietrich, W.E., and Smith, J.D., 1983, Influence of the point bar on flow through curved channels: Water Resources Research, v. 19, p. 1173-1192, doi:10.1029/WR019i005p01173.

Dykaar, B.B., 2005, Status and trends of the Middle and Coast Forks Willamette River and their floodplain habitat using geomorphic indicators: Prepared by Ecohydrology West, Santa Cruz, California, for Willamette Partnership, Salem, Oregon, and U.S. Army Corps of Engineers, Portland, Oregon, 78 p. 
Dykaar, B.B., 2008a, A catalogue of geomorphic change on the Middle and Coast Forks of the Willamette River using recent aerial orthophotography: Prepared by Ecohydrology West, Santa Cruz, California, for U.S. Army Corps of Engineers, Portland, Oregon, and Oregon Department of Fish and Wildlife, Salem, 37 p.

Dykaar, B.B., 2008b, A preliminary examination of some hydrogeomorphic factors limiting black cottonwood recruitment on the Middle and Coast Forks of the Willamette River; Prepared by Ecohydrology West, Santa Cruz, California, for U.S. Army Corps of Engineers, Portland, Oregon and Oregon Department of Fish and Wildlife, Salem, 40 p.

Dykaar, B.B., and Wigington, P.J., Jr., 2000, Floodplain formation and cottonwood colonization patterns on the Willamette River, Oregon, USA: Environmental Management, v. 25, p. 87-104.

Everitt, B.L., 1968, Use of the cottonwood in an investigation of the recent history of a floodplain: American Journal of Science, v. 266, p. 417-439.

Fernald, A.G., Wigington, P.J., Jr., and Landers, D.H., 2001, Transient storage and hyporheic flow along the Willamette River, OregonModel estimates and field measurements: Water Resources Research, v. 37, no. 6, p. 16811694.

Fierke, M.K., and Kauffman, J.B., 2005, Structural dynamics of riparian forests along a black cottonwood successional gradient: Forest Ecology and Management, v. 215, nos. 1-3, p. 149-162, doi:10.1016/j.foreco.2005.06.014.

Fierke, M.K., and Kauffman, J.B., 2006a, Invasive species influence riparian plant diversity along a successional gradient, Willamette River, Oregon: Natural Areas Journal, v. 26, no. 4, p. 376-382, doi:10.3375/08858608(2006)26[376:isirpd]2.0.co;2.

Fierke, M.K., and Kauffman, J.B., 2006b, Riverscape-level patterns of riparian plant diversity along a successional gradient,
Willamette River, Oregon: Plant Ecology, v. 185, no. 1, p. 85-95, doi:10.1007/s11258-0059086-Z.

Fletcher, W.B., and Davidson, L.D., 1988, South Santiam River bank protection study, pilot project for Willamette River bank protection study: Portland, Oregon, U.S. Army Corps of Engineers [variously paged].

Gilbert, G.K., and Murphy, E.C., 1914, The transportation of debris by running water: U.S. Geological Survey Professional Paper 86, 263 p.

Grant, G.E., 2012, The geomorphic response of gravel-bed rivers to dams-Perspectives and prospects, in Church, Michael, Biron, P.M., and Roy, A.G., eds., Gravel-bed rivers VIIProcesses, tools, environments: Chichester, United Kingdom, Wiley, p 165-181.

Grant, G.E., Lewis, S.L., Swanson, F.J., Cissel, J.H., and McDonnell, J.J., 2008, Effects of forest practices on peak flows and consequent channel response-A state-of-science report for western Oregon and Washington: Portland, Oregon, U.S. Department of Agriculture, Forest Service, Pacific Northwest Research Station, General Technical Report PNW-GTR760, $76 \mathrm{p}$.

Gregory, S., 2008, Historical channel modification and floodplain forest declineImplications for conservation and restoration of a large floodplain river-Willamette River, Oregon, in Habersack, Helmut, Piegay, Hervey, and Rinaldi, Massimo, eds., Gravel-bed rivers $\mathrm{VI}$-From process understanding to river restoration: Elsevier B.V., p. 763-777.

Gregory, S., Ashkenas, L., Haggerty, P., Oetter, D., Wildman, K., Hulse, D., Branscomb, A., and Van Sickle, J., 2002a, Riparian vegetation, in Hulse, D., Gregory, S., and Baker, J., eds., Willamette River Basin atlas: Corvallis, Oregon State University Press, p. 40, accessed August 23, 2013, at http://oregonstate.edu/dept/pnw-erc/.

Gregory, S., Ashkenas, L., and Nygaard, C., 2007, Summary report to assist development 
of ecosystem flow recommendations for the Middle Fork and Coast Fork of the Willamette River, Oregon: Corvallis, Oregon State University, Institute for Water and Watersheds, $237 \mathrm{p}$.

Gregory, S., Ashkenas, L., Oetter, D., Minear, P., and Wildman, K., 2002b, Historical Willamette River channel change, in Hulse, D., Gregory, S., and Baker, J., eds., Willamette River Basin atlas: Corvallis, Oregon State University Press, p. 18-24, accessed August 23, 2013, at http://oregonstate.edu/dept/pnwerc/.

Gregory, S., Ashkenas, L., Oetter, D., Wildman, R., Minear, P., Jett, S., and Wildman, K., 2002c, Revetments, in Hulse, D., Gregory, S., and Baker, J., eds., Willamette River Basin atlas: Corvallis, Oregon State University Press, p. 32-33, accessed August 23, 2013, at http://oregonstate.edu/dept/pnw-erc/.

Gregory, S., Wildman, R., Ashkenas, L., Wildman, K., and Haggerty, P., 2002d, Fish assemblages, in Hulse, D., Gregory, S., and Baker, J., eds., Willamette River Basin Atlas: Corvallis, Oregon State University Press, p. 44-45, accessed August 23, 2013, at http://oregonstate.edu/dept/pnw-erc/.

Gregory, S., and Hulse, D., 2002, Conceptual and spatial framework, in Hulse, D., Gregory, S., and Baker, J., eds., Willamette River Basin atlas: Corvallis, Oregon State University Press, p. 132-33, accessed August 23, 2013, at http://oregonstate.edu/dept/pnw-erc/.

Gutowsky, S., 2000, Riparian cover changes associated with flow regulation and bank stabilization along the upper Willamette River in Oregon between 1939 and 1996: Corvallis, Oregon State University, M.S. thesis, 92 p.

Harmon, M.E., Franklin, J.F., Swanson, F.J., Sollins, Phil, Gregory, S.V., Lattin, J.D., Anderson, N.H., Cline, S.P., Aumen, N.G., Sedell, J.R., Lienkaemper, G.W., Cromack, K. Jr., and Cummins, K.W., 1985, Ecology of coarse woody debris in temperate ecosystems, in Advances in Ecological Research, v. 15, no. 133, p. 302.

Harr, R.D., 1981, Some characteristics and consequences of snowmelt during rainfall in western Oregon: Journal of Hydrology, v. 53, p. 277-304.

Hickin, E.J., and Nanson, G.C., 1984, Lateral migration rates of river bends: Journal of Hydraulic Engineering, v. 110, no. 11, p. 15571567.

Hulse, D.W., Branscomb, A., Enright, C., Gregory, S.V., and Wildman, R., 2007, Linking coldwater refuges into a biologically effective network in the southern Willamette River floodplain-Outlining key locations and knowledge gaps: Prepared for David Evans and Associates, Portland, Oregon, 37 p., accessed August 23, 2013, at http://ise.uoregon.edu/publications.html.

Hulse, D.W., Gregory, S.V., and Wright, S., 2012, Assessment of potential for improving ESA-listed fish habitat associated with operations and maintenance of the U.S. Army Corps of Engineers Willamette Project-An approach to prioritizing revetments for removal or modification to restore natural river function: Prepared for U.S. Army Corps of Engineers, Portland District, Portland, Oregon, 64 p.

Jefferson, Anne, Grant, Gordon, and Rose, Tim, 2006, Influence of volcanic history on groundwater patterns on the west slope of the Oregon High Cascades: Water Resources Research, v. 42, W12411, doi:10.1029/2005WR004812.

Jefferson, A.J., 2011, Seasonal versus transient snow and the elevation dependence of climate sensitivity in maritime mountainous regions: Geophysical Research Letters, v. 38, L16402, doi:10.1029/2011GL048346.

Jones, K.L., O'Connor, J.E., Keith, M.K., Mangano, J.F., and Wallick, J.R., 2012, Preliminary assessment of channel stability and bedmaterial transport in the Rogue River Basin, southwestern Oregon: U.S. Geological Survey 
Open-File Report 2011-1280, 96 p. (Also available at

http://pubs.usgs.gov/of/2011/1280/.)

Junk, W.J., Bayley, P.B., and R.E. Sparks, 1989, The flood pulse concept in river-floodplain systems, in Dodge, D.P., ed., Proceedings of the International Large River Symposium: Canadian Special Publication of Fisheries and Aquatic Sciences 106, p. 110-227.

Keller, E., and Swanson, F., 1979, Effects of large organic material on channel form and fluvial processes: Earth Surface Processes, v. 4, p. 361-380.

Klingeman, P.C., 1973, Indications of streambed degradation in the Willamette Valley: Corvallis, Department of Civil Engineering, Oregon State University, Water Resources Research Institute Report WRRI-21, 99 p.

Klingeman, P.C., 1987, Geomorphic influences on sediment transport in the Willamette River, in Beschta, R.L., Blinn, T., Grant, G.E., Swanson, F.J., and Ice, G.G., eds., Erosion and the Pacific Rim, Proceedings of the Corvallis Symposium, August 1987: Corvallis, Oregon, U.S. Department of Agriculture, Forest Service, Pacific Northwest Research Station, IAHS publication no. 165, p. 365-374.

Kondolf, G. M., 1994, Geomorphic and environmental effects of in-stream gravel mining: Landscape and Urban Planning, v. 28, nos. 23, p. 225-243.

Kondolf, G. M., Smeltzer, Matt, and Kimball, Lisa, 2002, Freshwater gravel mining and dredging issues: White paper prepared by the Center for Environmental Design Research, University of California at Berkeley, for the Washington Department of Fish and Wildlife, Washington Department of Ecology, and Washington Department of Transportation, $122 \mathrm{p}$.

Landers, D., Fernald, A., and Andrus, C., 2002, Off-channel habitats, in Hulse, D., Gregory, S., and Baker, J., eds., Willamette River Basin atlas: Corvallis, Oregon State University Press, p. 32-33, accessed August 23, 2013, at http://oregonstate.edu/dept/pnw-erc/.

Leopold, L.B., and Langbein, W.B., 1962, The concept of entropy in landscape evolution: U.S. Geological Survey Professional Paper 500-A, 20p. (Also available at http://pubs.er.usgs.gov/publication/pp500A.)

Lignon, F., Dietrich, W., and Trush, W., 1995, Downstream ecological effects of dams, a geomorphic perspective: Bioscience, v. 45, p. 183-192.

Lower Columbia Estuary Partnership, 2013, Columbia River estuary ecosystem classification: Lower Columbia Estuary Partnership Web site, accessed September 5, 2013, at http://www.estuarypartnership.org/columbiariver-estuary-ecosystem-classification.

Luce, C.H., and Holden, Z.A., 2009, Declining annual streamflow distributions in the Pacific Northwest United States, 1948-2000: Geophysical Research Letters, v. 36, L16401, doi:10.1029/2009GL039407.

Mass, C., Skalenakis, A., and Warner, M., 2011, Extreme precipitation over the West Coast of North America-Is there a trend?: Journal of Hydrometeorology, v. 12, p. 310-318, http://dx.doi.org/10.1175/2010JHM1341.1.

Micheli, E., and Kirchner, J., 2002, Effects of wet meadow riparian vegetation on streambank erosion, 1 -Remote sensing measurements of streambank migration and erodibility: Earth Surface Processes and Landforms, v. 27, p. 627-639.

Minear, P.J., 1994, Historical change in channel form and riparian vegetation of the McKenzie River, Oregon: Corvallis, Oregon State University, M.S. thesis, 175 p., 24 figs.

Montgomery, D.R., and Abbe, T.B., 2006, Influence of logjam-formed hard points on the formation of valley-bottom landforms in an oldgrowth forest valley, Queets River, Washington, USA: Quaternary Research, v. 65, p. 147155.

Nadler, C.T., and Schumm, S.A., 1981, Metamorphosis of South Platte and Arkansas 
Rivers, eastern Colorado: Physical Geography, v. 2, p. 95-115.

Naiman, R.J., Bechtold, J.S., Beechie, T.J., Latterell, J.J., and van Pelt, R., 2010, A process-based view of floodplain forest patterns in coastal river valleys of the Pacific Northwest: Ecosystems, v. 13, no. 1, p. 1-31.

National Marine Fisheries Service, 2008, Endangered Species Act section 7(a)(2) consultation biological opinion and Magnuson-Stevens Fishery Conservation and Management Act essential fish habitat consultation on the Willamette River Basin Flood Control Project: National Marine Fisheries Service, Northwest Region, Seattle, Washington, National Oceanic and Atmospheric Administration Fisheries Log Number: FINWR12000/02117 [variously paged], accessed April 9, 2013, at http://www.nwr.noaa.gov/hydropower/willame tte_opinion/index.html.

Noble, M.G. 1979, The origin of Populus deltoides and Salix interior zones on point bars along the Minnesota River: American Midland Naturalist, v. 102, p. 59-67.

O’Connor, J.E., and Benito, G., 2009, Late Pleistocene Missoula floods-15,000-20,000 calendar years before present from radiocarbon dating: Geological Society of America Annual Meeting, Portland, Oregon, October 18-21, 2009, Abstracts with Programs, v. 41, no. 7, p. 169, Paper No. 55-7.

O’Connor, J.E., Jones, M.A., and Haluska, T.L., 2003, Flood plain and channel dynamics of the Quinault and Queets Rivers, Washington, USA: Geomorphology, v. 51, p. 31-59.

O'Connor, J.E., Mangano, J.F., Anderson, S.W., Wallick, J.R., Jones, K.L., and Keith, M.K., in press, Geologic and physiographic controls on bed-material yield, transport, and channel morphology for alluvial and bedrock rivers, western Oregon: Geological Society of America Bulletin.

O’Connor, J.E., Sarna-Wojcicki, A., Wozniak, K.E., Polette, D.J., and Fleck, R.J., 2001, Origin, extent, and thickness of Quaternary geologic units in Willamette Valley, Oregon: U.S. Geological Survey Professional Paper 1620, 52 p. and digital data, dataset accessed July 29, 2009, at http://or.water.usgs.gov/pubs_dir/Online/Cd/ WRIR99-4036/GIS_FILES/will_geol.html.

Opperman, J.J., Luster, R., McKenney, B.A., Roberts, M., and Meadows, A.W. 2010, Ecologically functional floodplains-

Connectivity, flow regime, and scale: Journal of the American Water Resources Association, v. 46, no. 2, p. 211-226, doi:10.1111/j.17521688.2010.00426.x.

Oregon State University, 2013a, Prism climate group: Corvallis, Oregon State University Web site, accessed August 19, 2013, at http://www.prism.oregonstate.edu/.

Oregon State University, 2013b, Willamette Water 2100: Corvallis, Oregon State University Web site, accessed August 19, 2013, at http://water.oregonstate.edu/ww2100/.

Oregon Water Resources Department and U.S. Army Corps of Engineers, 1998, Willamette Basin reservoirs-An overview of US Army Corps of Engineers dams and reservoirs on Willamette River tributaries, brochure accessed August 23, 2013, at http://www.oregon.gov/owrd/docs/1998_04_W illamette_Brochure.pdf.

Payne, S., 2002, Dams, in Hulse, D., Gregory, S., and Baker, J., eds., Willamette River Basin atlas: Corvallis, Oregon State University Press, p. 32-33, accessed August 23, 2013, at http://oregonstate.edu/dept/pnw-erc/.

Petts, G.E., and Gurnell, A.M, 2005, Dams and geomorphology: research progress and future directions: Geomorphology, v. 71, p. 27-47.

Planty-Tabacchi, Anne-Marie, Tabacchi, Eric, Naiman, R.J., Deferrari, Collette, and Decamps, Henri, 1996, Invasibility of speciesrich communities in riparian zones: Conservation Biology, v. 10, no. 2, p. 598607, doi:10.2307/2386875.

Poole, G.C., O'Daniel, S.J., Jones, K.L., Woessner, W.W., Bernhardt, E.S., Helton, 
A.M., Stanford, J.A., Boer, B.R., and Beechie, T.J., 2008, Hydrologic spiralling-The role of multiple interactive flow paths in stream ecosystems: River Research and Applications, v. 24, no. 7, p. 1018-1031, doi:10.1002/rra.1099.

Poole, G.C., Stanford, J.A., Running, S.W., and Frissell, C.A., 2006, Multiscale geomorphic drivers of groundwater flow pathsSubsurface hydrologic dynamics and hyporheic habitat diversity: Journal of the North American Benthological Society, v. 25, no. 2, p. 288-303.

Risley, J.C., Wallick, J.R., Mangano, J.F., and Jones, K.L, 2012, An environmental streamflow assessment for the Santiam River Basin, Oregon: U.S. Geological Survey Open-File Report 2012-1133, 66 p. (Also available at http://pubs.usgs.gov/of/2012/1133/.)

Risley, John, Wallick, J.R., Waite, Ian, and Stonewall, Adam, 2010, Development of an environmental flow framework for the McKenzie River Basin, Oregon: U.S. Geological Survey Scientific Investigations Report 2010-5016, 94 p. (Also available at http://pubs.usgs.gov/sir/2010/5016/.)

River Design Group, Inc., 2012a, McKenzie River floodplain inundation mapping: Completed for The Nature Conservancy, Corvallis, Oregon, 31 p. plus maps.

River Design Group, Inc., 2012b, Willamette River floodplain inundation mapping - Eugene to Oregon City, Oregon: Completed for the Meyer Memorial Trust, Corvallis, Oregon, 55 p.

Rollet, A. J., Piégay, H., Dufour, S., Bornette, G., and Persat, H., 2013, Assessment of consequences of sediment deficit on a gravel river bed downstream of dams in restoration perspectives-Application of a multicriteria, hierarchical and spatially explicit diagnosis: River Research and Applications, doi:10.1002/rra.2689.

Sedell, J.R., and Froggatt, J.L., 1984, Importance of streamside forests to large rivers-The iso- lation of the Willamette River, Oregon, USA, from its floodplain by snagging and streamside forest removal: Verhandlungen der Internationale Vereinigung fur Theoretische und Angewandte Limnologie, v. 22, p. 1828-1834.

Simenstad, C.A., Burke, J.L., O’Connor, J.E., Cannon, C., Heatwole, D.W., Ramirez, M.F., Waite, I.R., Counihan, T.D., and Jones, K.L., 2011, Columbia River estuary ecosystem classification-Concept and application: U.S. Geological Survey Open-File Report 20111228, 54 p. (Also available at http://pubs.usgs.gov/of/2011/1228.)

Simon, A., and Collison, A.J., 2002, Quantifying the mechanical and hydrologic effects of riparian vegetation on streambank stability: Earth Surface Processes and Landforms, v. 27, p. 527-546.

Sommer, T.R., Nobriga, M.L., Harrell, W.C., Batham, Wendy, and Kimmerer, W.J., 2001, Floodplain rearing of juvenile Chinook salmon-Evidence of enhanced growth and survival: Canadian Journal of Fisheries and Aquatic Science, v. 58, p. 325-333.

Stearns, H.T., 1928, Geology and water resources of the Upper McKenzie Valley, Oregon, in Grover, Nathan, C., ed., Contributions to the hydrology of the United States: U.S. Geological Survey Water Supply Paper 597-D, p. 171-188.

Stella, J.C., Hayden, M.K., Battles, J.J., Piegay, H., Dufour, S. and Fremier, A.K., 2011, The role of abandoned channels as refugia for sustaining pioneer riparian forest ecosystems: Ecosystems, v. 14, p. 776-790.

Tabacchi, E., Correll, D.L., Hauer, R., Pinay, G., Planty-Tabacchi, A., and Wissmar, R.C., 1998, Development, maintenance and role of riparian vegetation in the river landscape: Freshwater Biology, v. 40, no. 3, p. 497-516, doi:10.1046/j.1365-2427.1998.00381.x.

Tague, C., and Grant, G.E., 2004, A geological framework for interpreting the low flow regimes of Cascade streams, Willamette River Basin, Oregon: Water Resources Research, v. 
40, no. 4, p. W04303, doi:

10.1029/2003WR002629

The Nature Conservancy, 2013, Modernizing water management-Building a national sustainable rivers program: The Nature Conservancy Web site, accessed September 4, 2013, at http://www.nature.org/ourinitiatives/habitats/r iverslakes/sustainable-rivers-project.xml."

Thorne, C.R., 1990, Effects of vegetation on riverbank erosion and stability, in Thornes, J.B., ed., Vegetation and erosion: Chichester, United Kingdom, Wiley p. 125-144.

Thorne, S.D., and Furbish, D.J., 1995, Influences of coarse bank roughness on flow within a sharply curved river bend: Geomorphology, v. 12, p. 241-257.

University of Washington, PC Trask and Associates, Inc., Bottom, D., Goodwin, P., Hood, G., Stanford, J., and Teel, D., 2011, Landscape planning framework for restoration and protection of juvenile salmon habitat in the Columbia River estuary: PC Trask and Associates, Inc., Brochure, 4 p., accessed August 20, 2013, at http://www.pctrask.com/assets/files/Landscape \%20Planning\%20Framework\%20Brochure.pd $f$.

U.S. Army Corps of Engineers, 1875, Annual report of Chief of Engineers to the Secretary of War for the year 1875, Part II: Washington, D.C., U.S. Government Printing Office [variously paged].

U.S. Army Corps of Engineers, 1969, Willamette Basin comprehensive study, Appendix E. Flood Control: Willamette Basin Task ForcePacific Northwest River Basins Commission: U.S. Army Corps of Engineers, 136 p.

U.S. Department of Agriculture, 2012, Soil Survey Geographic (SSURGO) Database for Oregon: U.S. Department of Agriculture, Natural Resources Conservation Service, Soil Survey
Staff, digital data, accessed May 2012, at http://soildatamart.nrcs.usda.gov.

Wallick, J.R., Anderson, S.W., Cannon, Charles, and O'Connor, J.E., 2010, Channel change and bed-material transport in the lower Chetco River, Oregon: U.S. Geological Survey Scientific Investigations Report 2010-5065, 68 p.

(Also available at http://pubs.usgs.gov/sir/2010/5065/.)

Wallick, J.R., Grant, G.E., Lancaster, S.T., Bolte, J.P., and Denlinger, R.P., 2007, Patterns and controls on historical channel change in the Willamette River, Oregon, in Gupta, A.V., ed., Large rivers - Geomorphology and management: Chichester, United Kingdom, Wiley, p. 491-516.

Wallick, J.R., Lancaster, S.T., and Bolte, J.P., 2006, Determination of bank erodibility for natural and anthropogenic bank materials using a model of lateral migration and observed erosion along the Willamette River, OregonUSA: River Research and Applications, v. 22, p. 631-649.

Wallick, J.R., O'Connor, J.E., Anderson, Scott, Keith, Mackenzie, Cannon, Charles, and Risley, J.C., 2011, Channel change and bedmaterial transport in the Umpqua River Basin, Oregon: U.S. Geological Survey Scientific Investigations Report 2011-5041, 112 p. (Also available at http://pubs.usgs.gov/sir/2011/5041/.)

Wilcock, P.R., Pitlick, John, and Cui, Y.T., 2009, Sediment transport primer-Estimating bed-material transport in gravel-bed rivers: Fort Collins, Colorado, U.S. Department of Agriculture, Forest Service, Rocky Mountain Research Station, General Technical Report RMRS-GTR-226, 78 p. 
Appendix A. Geomorphic Descriptions of Valley Segments of the Willamette River Basin Study Area 


\section{Upper Segment of Willamette River}

The overall planform of the upper Willamette River between Corvallis (FPKM 168) and the confluence of the Coast and Middle Fork Rivers (FPKM 228; fig. A-1) is that of a "wandering gravel-bed river" (Church, 1983) dominated by a single channel, but also having multi-channeled segments separated by active gravel bars. This reach is the steepest and most dynamic of the entire main stem Willamette River with a low-flow water surface slope of 0.086 percent (figs. 3 and A-1).

Upstream of the McKenzie River confluence, the active channel mainly flows against resistant Pleistocene terraces (map unit $\mathrm{Qg}_{2}$ ) or revetments. It also is narrow (80-100 m wide) with few gravel bars or secondary channels. Immediately downstream of the McKenzie River confluence, however, the active channel widens to greater than $700 \mathrm{~m}$ in areas and has large, forested gravel bars and numerous secondary channels (for example, FPKMs 204 and 211). In this segment, the primary channel frequently shifts position, and is flanked by a nearly continuous string of unvegetated gravel bars ranging from 6,000 to $20,000 \mathrm{~m}^{2}$ in area. Between FPKMs 181 and 168 near Corvallis, the active channel returns to flowing mainly against resistant Pleistocene terraces or revetments. It also returns to a singlethread channel with few side channels and gravel bars that are flanked by mature vegetation.

Many floodplain sloughs, swales, and side channels occur throughout the segment (fig. A1). Many of these are relict features from the 19th-century braided active channel that have since coalesced into floodplain surfaces (Dykaar and Wigington, 2000).

Figure A-1. Upper segment of Willamette River, Oregon, floodplain and active channel. Upper: Map of floodplain topography, surficial geology and U.S. Army Corps of Engineers revetments. Lower: Example of active channel features, 1939-2011.

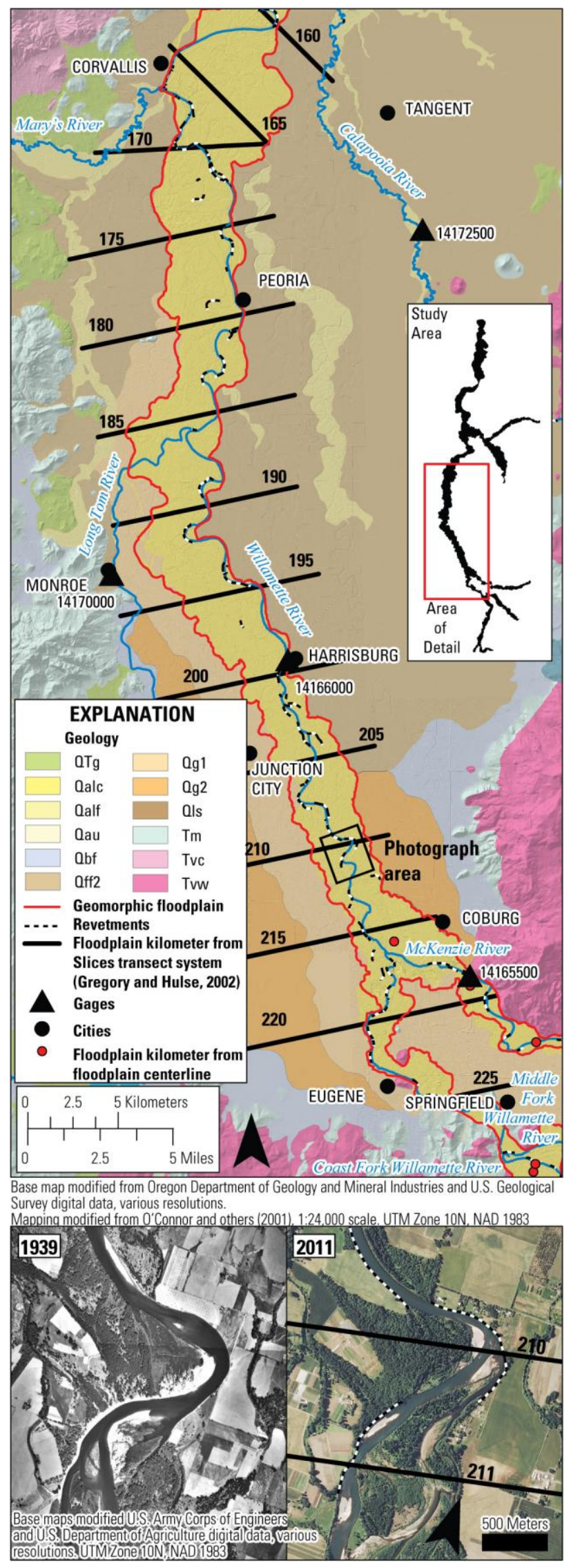




\section{Middle Segment of Willamette River}

The main stem Willamette River between Corvallis (FPKM 168) and the Santiam River confluence (FPKM 139) is a predominantly single-thread, low-gradient channel with a slope of 0.029 percent (figs. 3 and A-2). Floodplain width ranges from less than $1 \mathrm{~km}$ near FPKM 74 to greater than $6 \mathrm{~km}$ near FPKM 139. Between Corvallis and north Albany (FPKM 150), the position of the Willamette River alternates between opposite sides of the floodplain and has few meander bends except for the heavily revetted area near FPKM 160. Elsewhere, the channel is relatively straight and bordered by either Holocene alluvium (unit Qalc) or resistant Pleistocene gravels (unit $\mathrm{Qg}_{2}$ ), with very little revetment in comparison with other reaches.

The middle segment of the Willamette River has few actively shifting gravel bars other than a few large bars (up to $20,000 \mathrm{~m}^{2}$ in area) along the inside of the meander bends near FPKM 160, but elsewhere bars are densely vegetated, relict features from the historical flow and sediment regime. There are very few secondary channels, and floodplain sloughs are most prominent between FPKMs 161 and 153 and as the Willamette River approaches its confluence with the Santiam River where floodplain heights are relatively low (less than $3 \mathrm{~m}$ above the water surface of the primary channel) and relict meander scroll features are more prominent. The middle segment of the Willamette River is intrinsically stable owing to geology and physiography, and has relatively low rates of meander migration and avulsions compared to the upper segment of Willamette River (Wallick and others, 2007). Current channel stability is reflected in the scarcity of bare, active gravel bars and the nearly continuous band of mature trees bordering much of the channel.

Figure A-2. Middle segment of Willamette River, Oregon, floodplain and active channel. Upper: Map of floodplain topography, surficial geology and U.S. Army Corps of Engineers revetments. Lower: Example of active channel features,1939-2011.

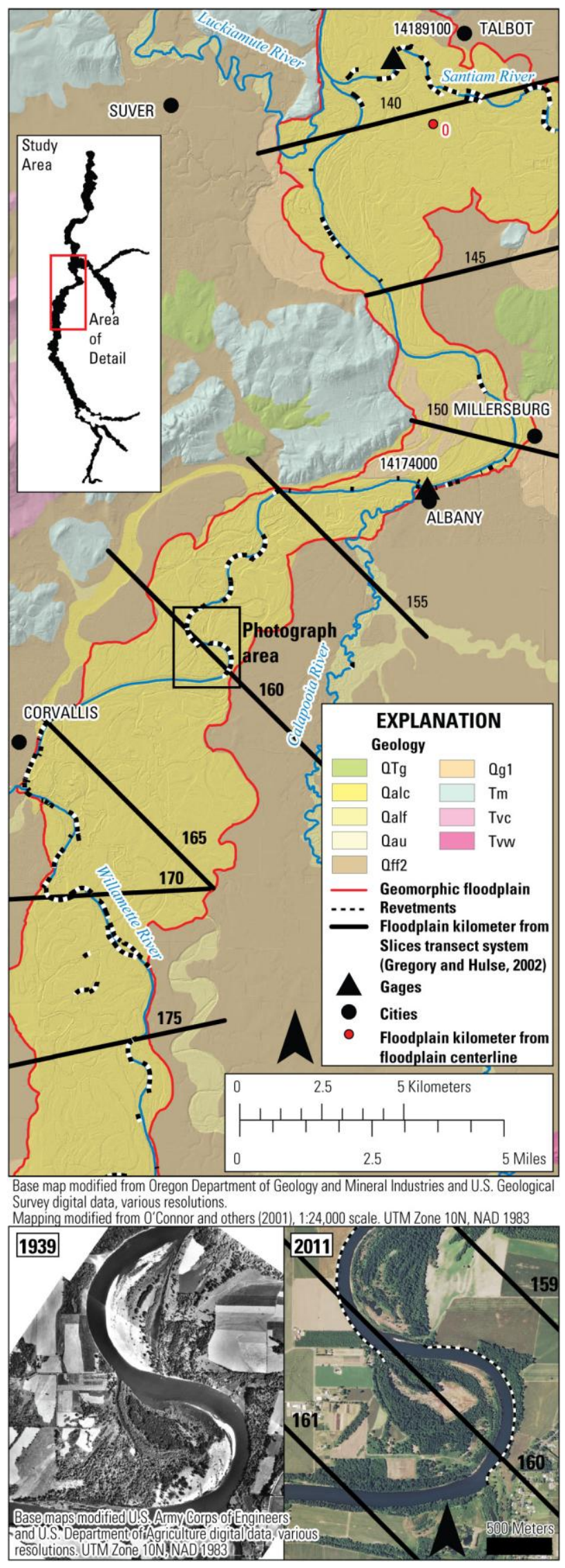




\section{Lower Segment of Willamette River}

The lower segment of the Willamette River between the confluence of the Santiam River (FPKM 139) and the Newberg Pool (FPKM 80) generally flows within a single channel that alternates position against paired terraces underlain by resistant Pleistocene gravels (unit $\mathrm{Qg}_{2}$, fig. A3 ). The primary channel has a very low gradient (0.035 percent, fig. 3 ) and is entrenched about $3-$ $6 \mathrm{~m}$ below adjacent floodplain surfaces. The lowest floodplain surfaces (and typically those that have the most extensive network of floodplain channels) are near the Santiam River confluence along the inside of broad sweeping bends (such as FPKM 132) and upstream of Salem (FPKMs 112-119), which also has been an area of extensive floodplain gravel extraction.

Although bare, actively shifting gravel bars generally are intermittent on the lower segment of the Willamette River, coarse sediment supplied by the Santiam River causes bars to be much larger and more numerous than those in the middle segment of the Willamette River. Patches of shifting gravel are generally narrow, small features $\left(6,000-11,000 \mathrm{~m}^{2}\right)$ along the edges of densely vegetated relict bars, but become larger (up to 50,000 $\mathrm{m}^{2}$ ) and more numerous immediately upstream of Salem (FPKMs 112119). Gravel bars also are more numerous as the Willamette River approaches the Newberg Pool where mid-channel bars range up to $100,000 \mathrm{~m}^{2}$.

Secondary channels are generally intermittent, but are more frequent downstream of FPKM 93. Although the lower segment of the Willamette River is much more geologically stable than the upper segment (Wallick and others, 2007), some unrevetted areas still show lateral migration as the channel shifts between gravel bars (FPKMs 80-81 and 86).

Figure A-3. Lower segment of Willamette River, Oregon, floodplain and active channel. Upper: Map of floodplain topography, surficial geology and U.S. Army Corps of Engineers revetments. Lower: Example of active channel features, 1939-2011.

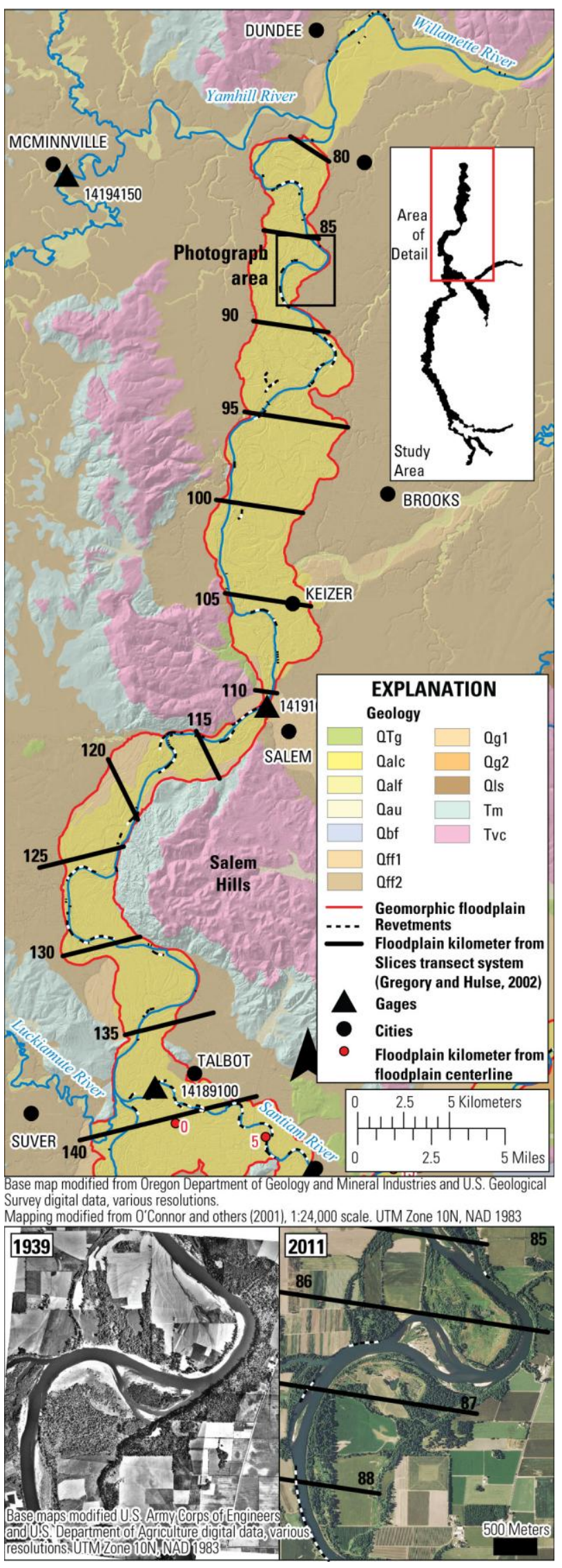




\section{Coast Fork Willamette River}

The lower, alluvial part of the Coast Fork Willamette River begins at its confluence with the Middle Fork Willamette River (FPKM 0) and extends upstream to FPKM 38 at Cottage Grove Dam. Floodplain width is greatest downstream of where the river enters the Western Cascades foothills, ranging from $0.5 \mathrm{~km}$ in areas such as FPKM 6 to about $2.2 \mathrm{~km}$ near its mouth. USACE revetments stabilize banks composed of Holocene alluvium (unit Qalc) along about one-half of the reach, particularly downstream of FPKM 6 where many gravel pits are in the former active channel (fig. A-4). The lower $3 \mathrm{~km}$ of the floodplain (where LiDAR topography is available) have many, densely vegetated floodplain sloughs and swales intersecting developed areas.

The Coast Fork Willamette River flows through a narrow (less than $50 \mathrm{~m}$ ) and stable channel that is bordered on both sides by nearly continuous bands of mature trees (fig. A-4). However, active channel width varies locally, and the channel is as wide as $200 \mathrm{~m}$ in areas such as FPKMs 4 and 8, where large gravel bars are present in sharp bends whose positions are fixed by valley morphology. The low-sinuosity primary channel has an average slope of 0.16 percent downstream of FPKM 14. Overall, there are very few secondary channels, and these channel features typically are short (less than $200 \mathrm{~m}$ long). The Coast Fork Willamette River has a few large $\left(4-15,000 \mathrm{~m}^{2}\right)$ active gravel bars downstream of FPKM 5, but upstream, smaller gravel bars (less than $2,000 \mathrm{~m}^{2}$ ) are intermittent. Although the reach is relatively stable owing to a combination of geology, physiography, and bank stabilization, bar growth and subsequent colonization by cottonwoods and willows was observed between 1979 and 2004 (Dykaar, 2005).

Figure A-4. Coast Fork Willamette River, Oregon, floodplain and active channel. Upper: Map of Coast Fork Willamette River floodplain topography, surficial geology and U.S. Army Corps of Engineers revetments. Lower: Example of active channel features, 1994-2011.

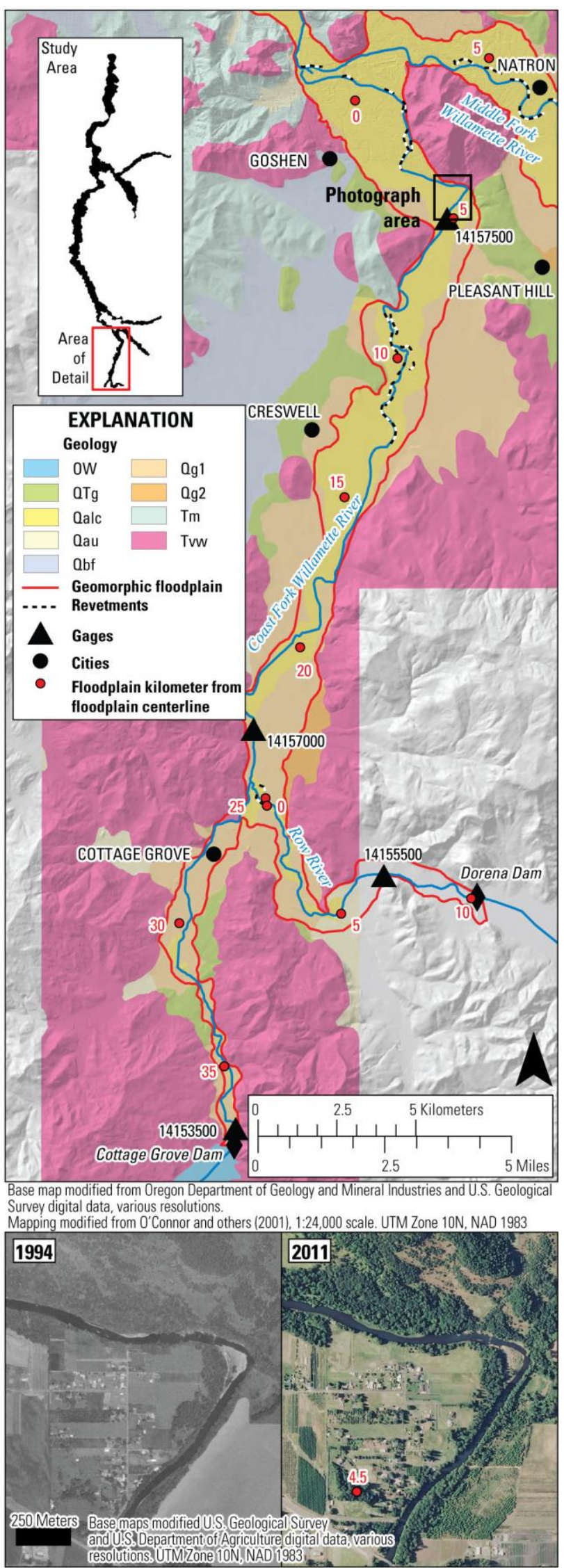




\section{Middle Fork Willamette River}

The lower $22 \mathrm{~km}$ of the Middle Fork Willamette River's floodplain downstream of Dexter Dam (FPKM 22) ranges in width from 1 to $2 \mathrm{~km}$ (fig. A-5). Within this segment, the river has a slope of 0.219 percent (fig. 3) and flows along the base of hillslopes underlain by Western Cascades volcanic rocks (unit Tvw) and also has sections flanked on both sides by erodible Holocene alluvium (unit Qalc; fig. A-5). Revetments are mainly along the historically dynamic section between FPKMs 3 and 9 (fig. A-5).

The Middle Fork Willamette River is predominantly single thread, but also has several multi-channeled sections near FPKMs 15-17 and 20-22, which provide important habitat for Oregon chub (fig. A-5). Most of these side channels appear predominantly stable and are bordered on both sides by mature trees. Bare, active gravel bars are mainly near the confluence with Fall Creek (FPKM 12) and along the lower $5 \mathrm{~km}$ of the reach and, although several bars are as large as $6,000 \mathrm{~m}^{2}$ in area, most are much smaller (less than $2,000 \mathrm{~m}^{2}$ ). Densely forested relict gravel bars from the historical flow and sediment regime are present along the entire reach.

The Middle Fork Willamette River is largely stable owing to a combination of substantial decreases in peak flows, bed-material supply, and local bank protection (fig. A-5). Previous studies show major decreases in gravel bars and side channels following dam construction and that the channel is much more stable now than it was historically (Dykaar, 2005; Dykaar, 2008a, 2008b). There also has been little change in overall channel conditions following high-flow releases under the Sustainable Rivers Program (Greg Taylor, U.S. Army Corps of Engineers, oral commun., Sept. 20, 2012).

Figure A-5. Middle Fork Willamette River, Oregon, floodplain and active channel. Upper: Map of floodplain topography, surficial geology and U.S. Army Corps of Engineers revetments. Lower: Example of active channel features, 1939-2011.

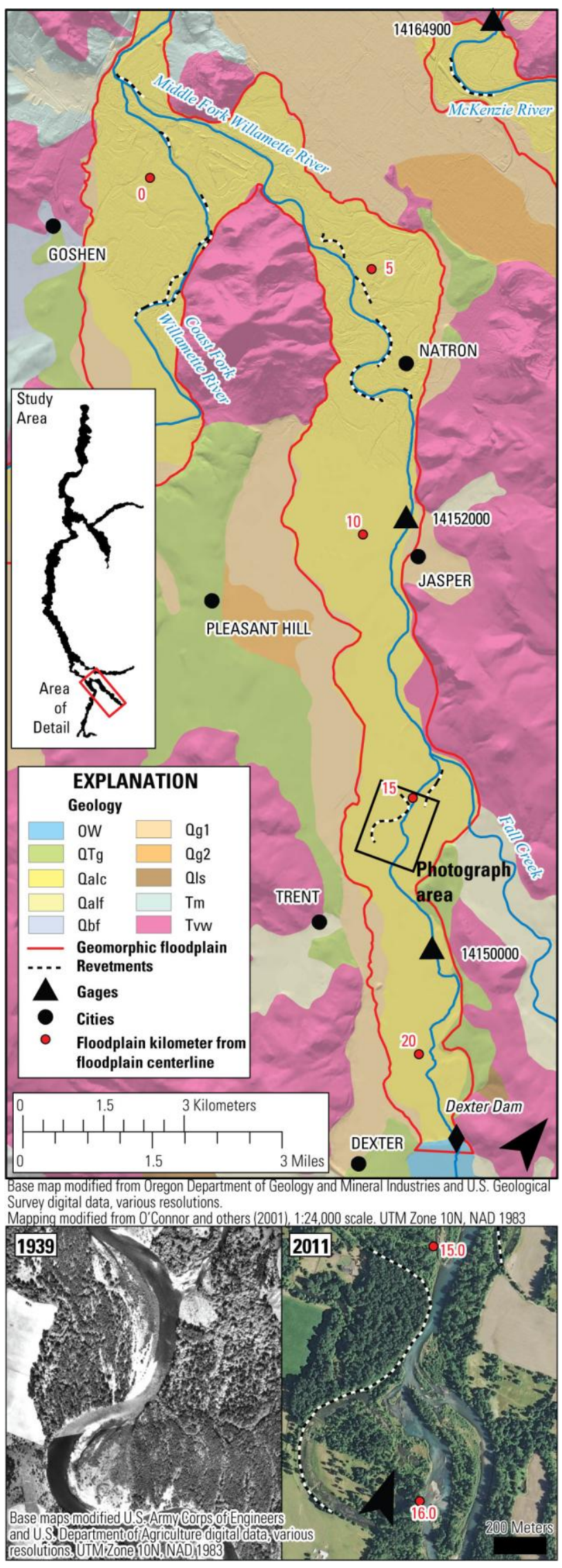




\section{McKenzie River}

The lower, alluvial $35 \mathrm{~km}$ of the McKenzie River floodplain downstream of Deerhorn ranges in width from about $100 \mathrm{~m}$ near Hayden Bridge (FPKM 14) to greater than $3 \mathrm{~km}$ near Coburg at its confluence with the Willamette River (FPKM 0 ), but typically is about $1.5 \mathrm{~km}$ wide. Along most of its length, the McKenzie River is flanked either by erodible Holocene alluvium (unit Qalc) (which is stabilized with revetment in many areas) or flows along the base of hillslopes composed of Western Cascades volcanic rocks (unit Tvw; fig. A-6).

Within the study area, the McKenzie River has a relatively steep slope (about 0.19 percent; fig. 3) and has single-thread and multi-channeled sections (fig. A-6). Upstream of Hayden Bridge, there are many bare or minimally vegetated gravel bars that range in area from 3,000 to
$30,000 \mathrm{~m}^{2}$ and multiple areas with alcoves and long (greater than $1 \mathrm{~km}$ ), side channels (FPKMs 24, 28, and 32) (fig. A-6). Floodplain surfaces are relatively low and more easily inundated by the 2-year flood (River Design Group, 2012a) causing floodplain sloughs to be more numerous than areas downstream of Hayden Bridge.

The McKenzie River between its confluence with the Willamette River and Hayden Bridge occupies a more stable single-thread channel than upstream areas and is flanked mostly by mature trees with fewer gravel bars and side channels. Along this section, gravel bars and secondary channels are mainly near the mouth of the McKenzie River and at FPKM 9 (fig. A-6). Between 1939 and 2005, there were large decreases in the area of active gravel bars and secondary channels (Risley and others, 2010), and many gravel bars present in the 1939 aerial photographs now are densely vegetated (fig. A-6).

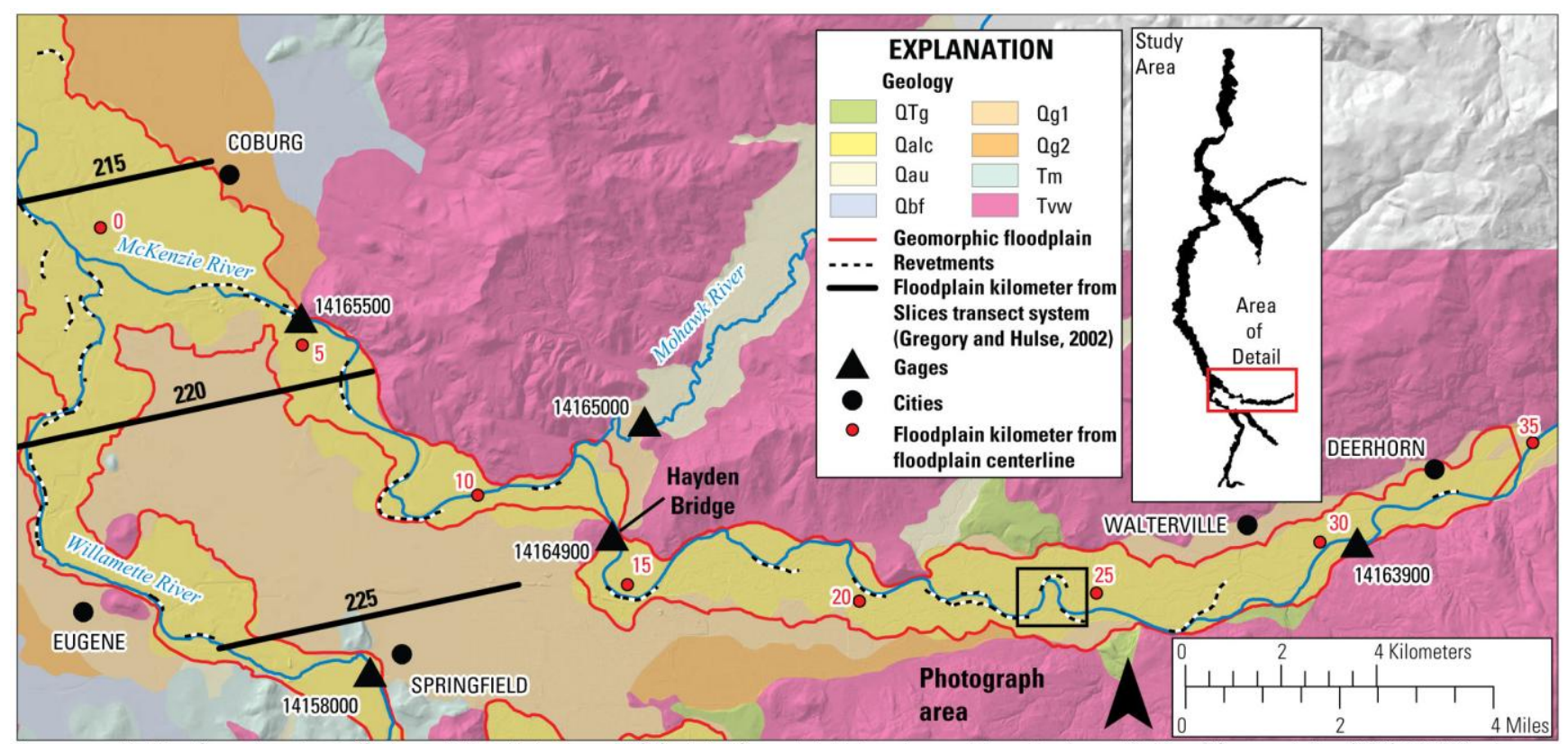

Base map modified from Oregon Department of Geology and Mineral Industries and U.S. Geological Survey digital data, various resolutions. Mapping modified from 0'Connor and others (2001), 1:24,000 scale. UTM Zone 10N, NAD 1983

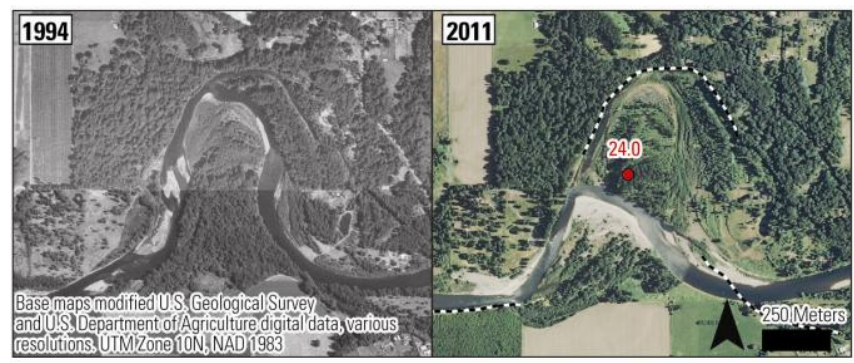

Figure A-6. McKenzie River, Oregon, flood-plain and active channel. Upper: Map of McKenzie River floodplain topography, surficial geology and U.S. Army Corps of Engineers revetments. Lower: Example of active channel features, 1939-2011. 


\section{South Santiam and Main Stem Santiam Rivers}

The South Santiam and main stem Santiam rivers flow through broad floodplains that range from 1 to $5 \mathrm{~km}$ wide and have channel slopes are 0.1321 percent and 0.087 percent, respectively. Along most of their lengths, these rivers were historically flanked on both sides by erodible Holocene alluvium; however, locally, individual bends such as FPKM 8 on the Santiam River and FPKMs $15-18$ on the South Santiam River impinge on older, more resistant Pleistocene terraces. Presently, nearly the entire South Santiam River has been stabilized along one or both banks by revetments, and much of the Santiam River also has been revetted (fig. A-7).

The overall planform of the present-day active channel along both rivers is predominantly single thread, with a few short (less than $1 \mathrm{~km}$ long) sections with side channels. Bare, active gravel bars are intermittent and, although several bars are as large as $50,000 \mathrm{~m}^{2}$ in unrevetted areas, most bars are much smaller (less than 5,000 $\mathrm{m}^{2}$ in area). Both rivers also are flanked by large, densely vegetated relict bar surfaces such as those shown along the inside of bends in figure A-7.

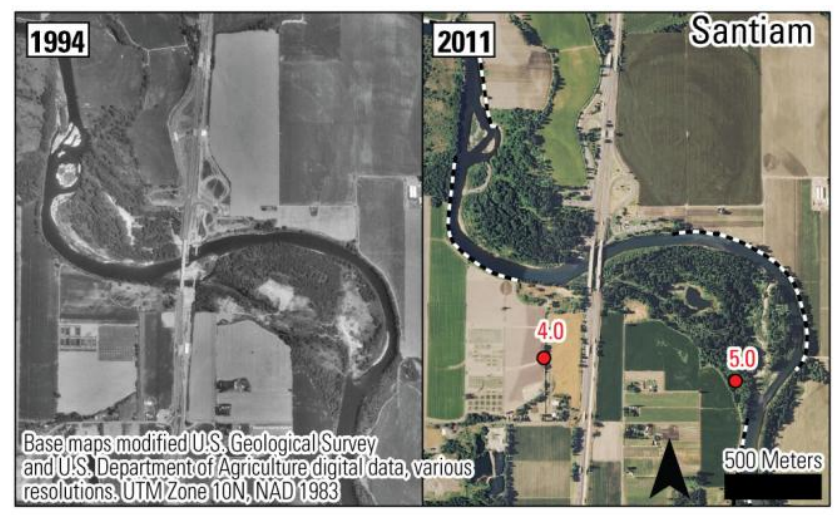

Figure A-7. Santiam River and South Santiam River, Oregon, floodplain and active channel. Upper right: Map of floodplain topography, surficial geology and U.S. Army Corps of Engineers revetments. Above and lower right: Examples of active channel features, 1994-2011.

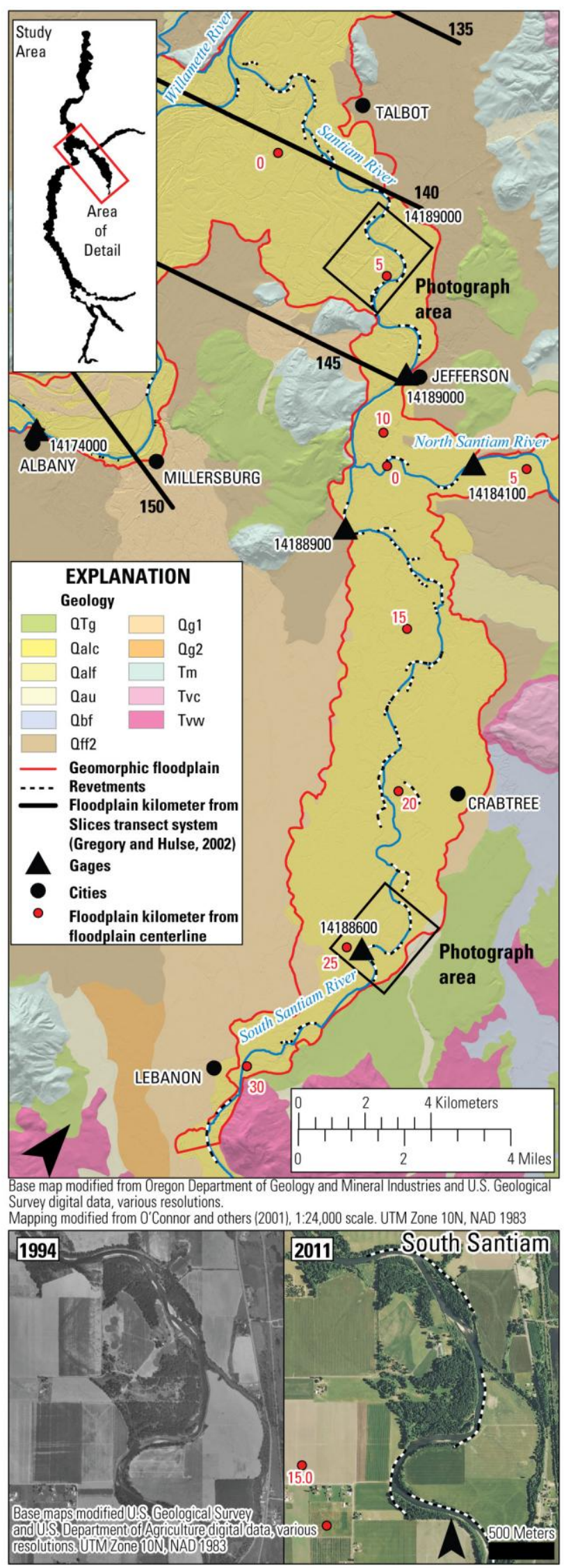




\section{North Santiam River}

The lower $30 \mathrm{~km}$ of the North Santiam River downstream of its confluence with the Little North Santiam River adopts a multi-threaded planform as the river flows through a floodplain ranging from 1 to $2 \mathrm{~km}$ wide (fig. A-8). Although there are very few USACE revetments, much of the active channel presently flows along resistant Pleistocene terraces or bedrock outcrops (fig. A-8).

The North Santiam River is the steepest river in the study area (0.28 percent; fig. 3; fig. A-8; table 3 ), and is relatively dynamic compared with other valley segments (fig. A-8). Along much of its length, the main channel is bordered by a diverse array of secondary channels ranging from recently formed alcoves to older, densely vegetated, secondary channels. Like other reaches in the study area, the active channel of the North Santiam is flanked by a nearly continuous swath of densely vegetated relict bar features. Upstream of FPKM 12, bare, active gravel bars are relatively small (less than $5,000 \mathrm{~m}^{2}$ ) and intermittent. Between FPKMs 12 and 5, the channel is actively shifting through a corridor of larger bare bars (up to $60,000 \mathrm{~m}^{2}$ ). The North Santiam River has had large-scale avulsions during recent decades, along with rapid rates of meander migration, which probably account for many bare gravel bars (fig. 12).

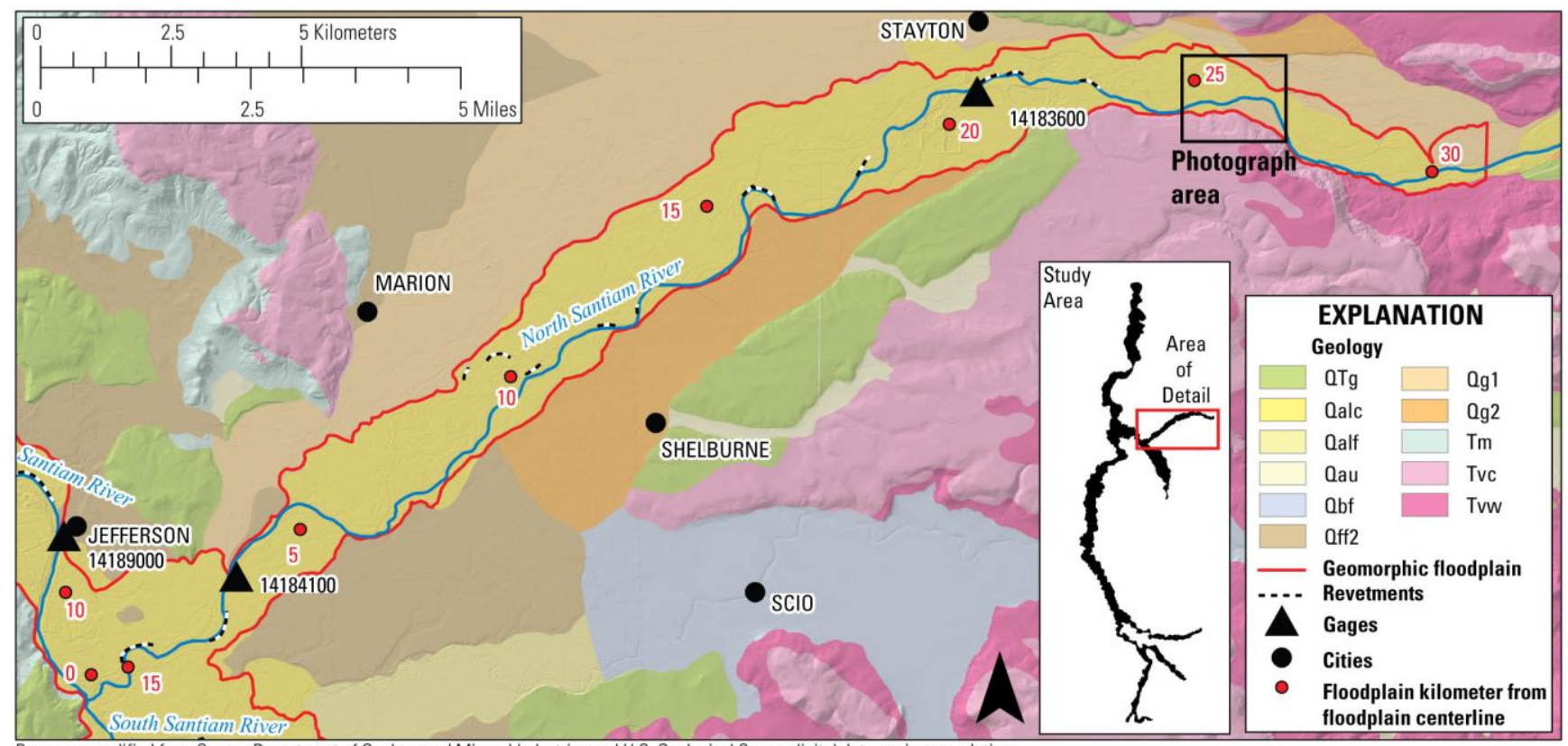

Base map modified from Oregon Department of Geology and Mineral Industries and U.S. Geological Survey digital data, various resolutions. Mapping modified from O'Connor and others (2001), 1:24,000 scale. UTM Zone 10N, NAD 1983

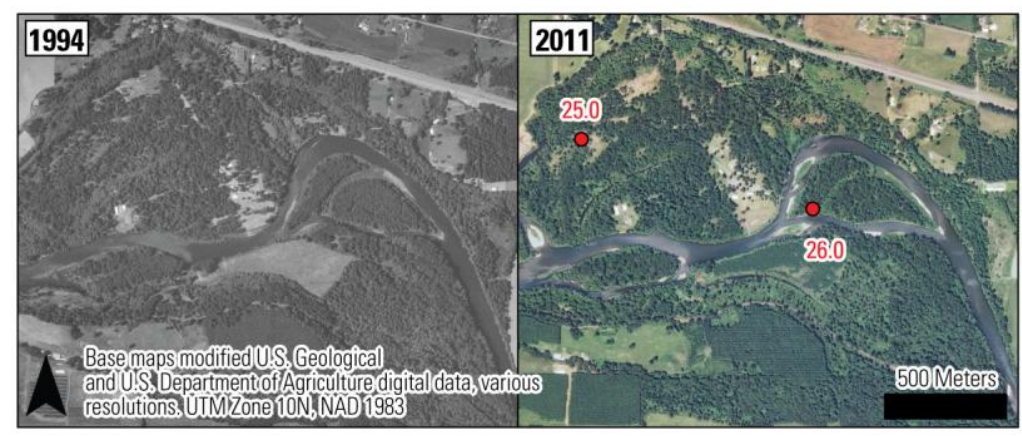

Figure A-8. North Santiam River, Oregon, floodplain and active channel. Upper: Map of North Santiam River floodplain topography, surficial geology and U.S. Army Corps of Engineers revetments. Lower: Example of active channel features, 1994-2011. 
응

응.

0

융

b

票 